Florida International University FIU Digital Commons

$4-1-2011$

\title{
Mercury interactions with suspended solids at the Upper East Fork Poplar Creek, Oak Ridge, Tennessee
}

Elsa Cabrejo

Florida International University

DOI: $10.25148 /$ etd.FI14052516

Follow this and additional works at: https://digitalcommons.fiu.edu/etd

Part of the Environmental Engineering Commons

\section{Recommended Citation}

Cabrejo, Elsa, "Mercury interactions with suspended solids at the Upper East Fork Poplar Creek, Oak Ridge, Tennessee" (2011). FIU Electronic Theses and Dissertations. 1953.

https://digitalcommons.fiu.edu/etd/1953 
FLORIDA INTERNATIONAL UNIVERSITY

Miami, Florida

MERCURY INTERACTIONS WITH SUSPENDED SOLIDS AT THE UPPER EAST FORK POPLAR CREEK, OAK RIDGE, TENNESSEE

A thesis submitted in partial fulfillment of the

requirements for the degree of

MASTER OF SCIENCE

in

ENVIRONMENTAL ENGINEERING

by

Elsa Cabrejo

2011 
To: Dean Amir Mirmiran

College of Engineering and Computing

This thesis, written by Elsa Cabrejo, and entitled Mercury Interactions with Suspended Solids at the Upper East Fork Poplar Creek, Oak Ridge, Tennessee, having been approved in respect to style and intellectual content, is referred to you for judgment.

We have read this thesis and recommend that it be approved.

Georgio Tachiev

Reinaldo Garcia

Fernahdo MirallesWilhelm, Major Professor

Date of Defense: April 1, 2011

The thesis of Elsa Cabrejo is approved.

Dean Amir Mirmiran
College of Engineering and Computing

Florida International University, 2011

ii 


\section{DEDICATION}

To the lights of my life,

Juliana and Samuel

iii 


\section{ACKNOWLEDGMENTS}

I would like to express my greatest gratitude to the people who have helped \& supported me throughout this project: my major professor, Dr. Fernando MirallesWilhelm, for his continuous advice, support and availability despite his busy schedule; Dr. Georgio Tachiev, for his guidance and knowledgeable inputs that made this project possible; and Dr. Reinaldo Garcia for his kind support and guidance.

During the project I had the opportunity to collaborate with colleagues in the Applied Research Center. I especially want to thank Dr. Siamak Malek Mohammadi for his direct involvement and great sharing of concepts and ideas, Ms. Peggy Shoffner for her helpful editorial comments, Camilo Arias, Angelique Lawrence, and Mandar Zope for sharing their experience in working with the software. I was also fortunate to have had Ms. Elizabeth Phillips as a mentor at the DOE-EM Oak Ridge. She guided me and gave first hand perspective on the importance of the topic under study.

I am grateful to Dr. Leonel Lagos, the director of the DOE Fellows program at the Applied Research Center, for giving me the opportunity to work on this project, and for supporting me until the end. I also wish to acknowledge the financial and programmatic support of the Department of Energy, office of Environmental Management.

I am especially grateful to my husband, Richard, for the patience and kind words that carried me through. I also wish to thank my lovely kids, Juliana and Samuel for their love and understanding. 


\title{
ABSTRACT OF THE THESIS
}

\section{MERCURY INTERACTIONS WITH SUSPENDED SOLIDS AT THE UPPER}

\section{EAST FORK POPLAR CREEK, OAK RIDGE, TENNESSE}

\author{
by
}

\section{Elsa Cabrejo}

Florida International University, 2011

$$
\text { Miami, Florida }
$$

Professor Fernando Miralles-Wilhelm, Major Professor

A water quality model was developed to analyze the impact of hydrological events on mercury contamination of the Upper East Fork Poplar Creek, Tennessee. The model simulates surface and subsurface hydrology and transport (MIKE SHE and MIKE 11) and it is coupled with the reactive transport of sediments and mercury (ECOLAB). The model was used to simulate the distribution of mercury contamination in the water and sediments as a function of daily hydrological events.

Results from the model show a high correlation between suspended solids and mercury in the water due to the affinity of mercury with suspended organics. The governing parameters for the distribution of total suspended solids and mercury contamination were the critical velocity of the stream for particle resuspension, the rates of resuspension and production of particles, settling velocity, soil-water partition coefficient, and desorption rate of mercury in the water. Flow and load duration curves at the watershed exit were used to calibrate the model and to determine the impact of hydrological events on the total maximum daily load at Station 17. The results confirmed the strong link between hydrology and mercury transport. 
4 RESEARCH METHODOLOGY.

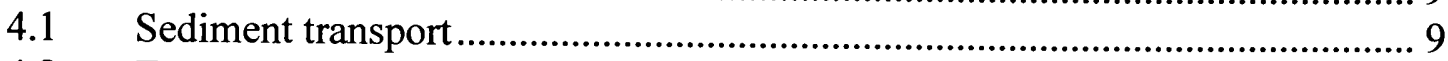

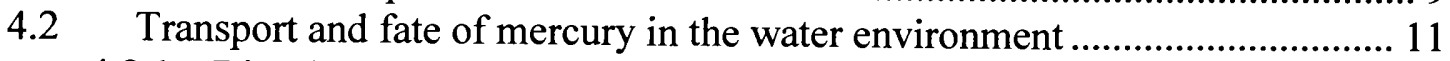

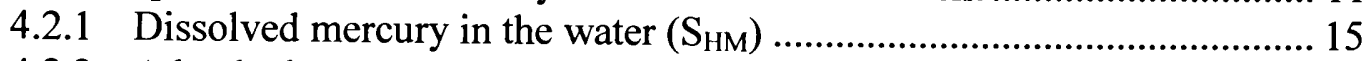

4.2.2 Adsorbed mercury concentration on suspended matter (XHM) ................ 17

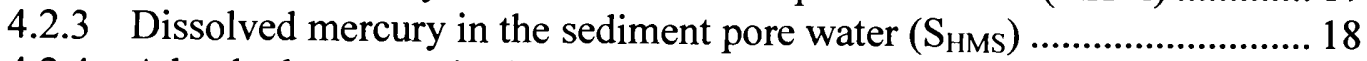

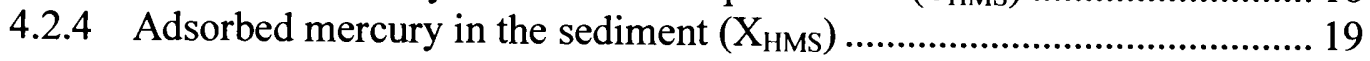

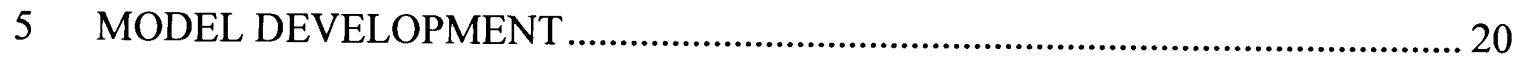

5.1 Parameters affecting suspended solids transport in ECOLAB ....................... 22

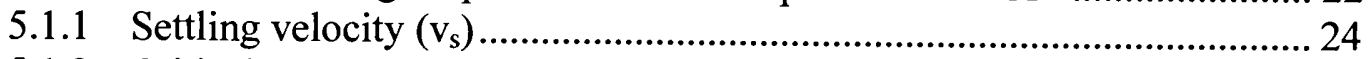

5.1.2 Critical current velocity for initiation of suspension $(\mathrm{Vc})$......................... 25

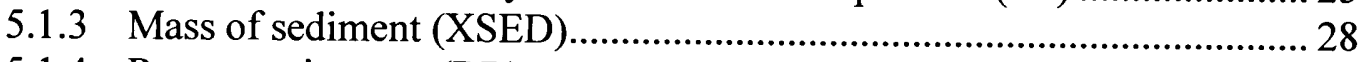

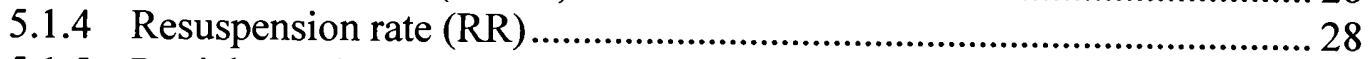

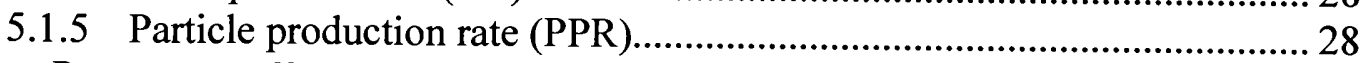

5.2 Parameters affecting mercury's fate and transport in ECOLAB ..................... 29

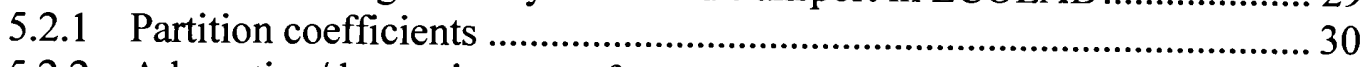

5.2.2 Adsorption/desorption rates from suspended matter and sediments....... 32

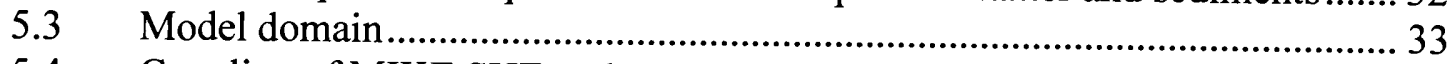

5.4 Coupling of MIKE SHE and MIKE 11 HD with ECOLAB ............................ 33

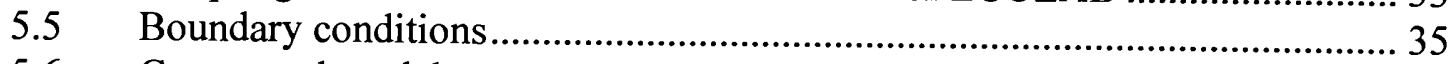

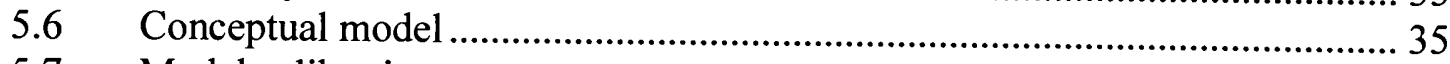

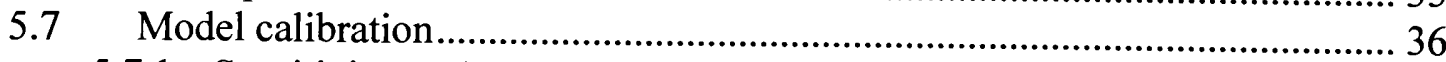

5.7.1 Sensitivity analysis for total suspended solids ....................................... 41

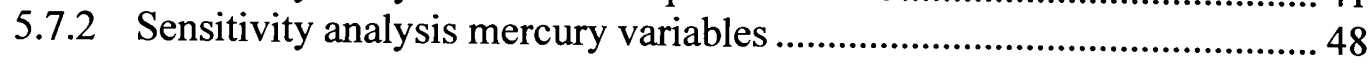

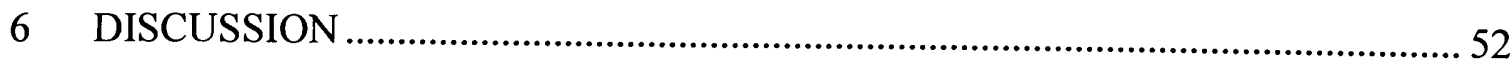

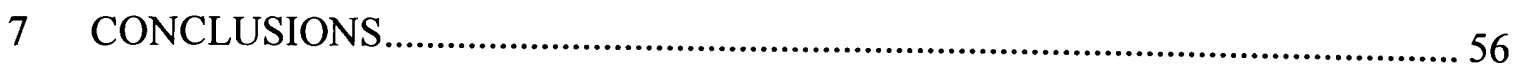

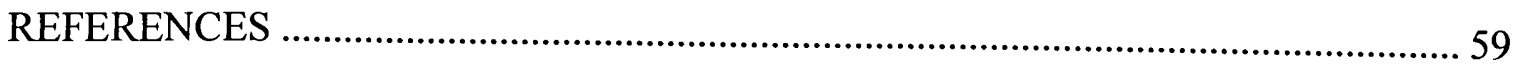




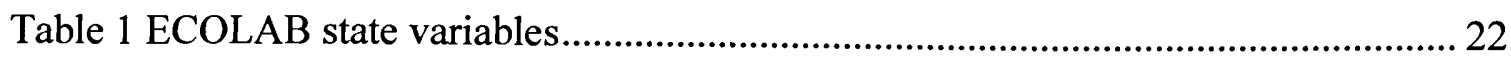

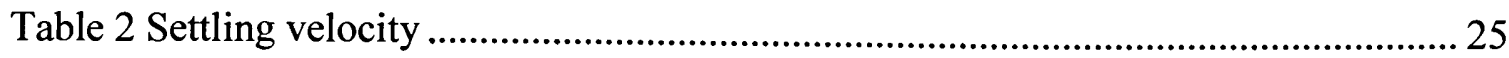

Table 3 Shields dimensionless parameters (L. Van Rijn 1984b)...................................... 26

Table 4 Mass of sediment at Station 17 (Southworth et. al., 2010) .................................. 27

Table $5 \log K_{d}(\mathrm{~L} / \mathrm{kg})$ values for inorganic mercury................................................ 30

Table 6 Probabilistic distribution observed flow UEFPC station 17 .............................. 38

Table 7 TSS, Load of TSS, load of $\mathrm{Hg}, 90^{\text {th }}$ and $50^{\text {th }}$ percentile, under different flow conditions (data from OREIS database, years 1996-2008)................................. 39

Table 8 Effect of changes in $k_{o c}$ in mercury concentrations in water and sediment......... 50

Table 9 Wentworth grade scale for particle size to standardize sieve diameters (Garde and Tanga Raju. 1985).......................................................................6 65

Table 10 Suspended sediments characterization (DOE, Instream Contaminat Study Task 2, V2. Sediment Characterization. 1986)..................................................6 66

Table 11 Data Collected for the bed sediment characterization (Moran 1996).................6 67

Table 12 Boundary conditions for East Fork Poplar Creek ............................................. 70

Table 13 UEFPC cross-sections description for chainages $0 \mathrm{~m}$ and $2663 \mathrm{~m}$.................... 72

Table 14 Dissolved and particulate mercury in the water column, observed data from UEFPC-Station 17 (Bechtel Jacobs 1999).

Table 15 Observed dissolved mercury in pore water, UEFPC (Source: OREIS database)

Table 16 Observed adsorbed mercury in sediment, UEFPC (OREIS database) ............... 75 


\section{LIST OF FIGURES}

FIGURE

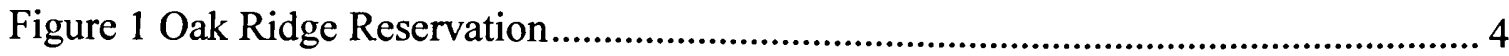

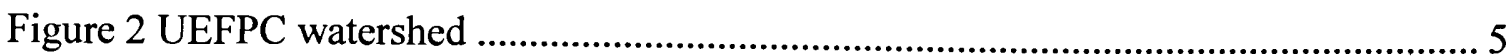

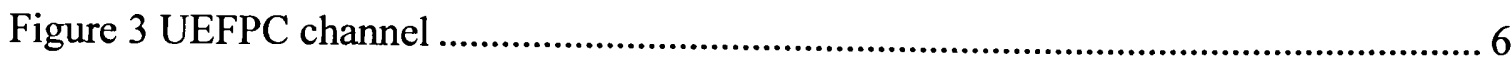

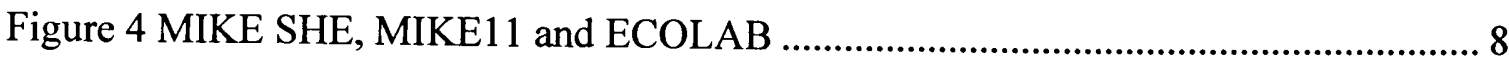

Figure 5 Schematic illustrating the interactions between metal, sediment, and water implemented in ECOLAB and MIKE 11....................................... 13

Figure 6 A typical MIKE SHE river link cross-section................................................... 35

Figure 7 Flow duration curve UEFPC Station 17(data from OREIS database years 1996-2008)

Figure 8 Load duration curve for suspended solids ranked by discharge at UEFPC Station 17 (data from OREIS database, years 1996-2009).

Figure 9 Total suspended solids by discharge at UEFPC Station 17 (data from OREIS database, years 1996-2009)

Figure 10 Load duration curve for mercury ranked by discharge at UEFPC

Station 17 (data from OREIS database, years 1996-2008). 40

Figure 11 Total Suspended Solids at the UEFPC Station 17. Data from OREIS database year 2000 .

Figure 12 Effect of critical current velocity in the load of TSS

Figure 13 Effect in TSS load by decreasing critical velocity

Figure 14 Effect of resuspension rate in the load of TSS

Figure 15 Effect in TSS load by increasing resuspension rate

Figure 16 Effect of settling velocity in the load of TSS

Figure 17 Effect in TSS load by decreasing settling velocity from 8 to $6 \mathrm{~m} / \mathrm{d}$. 46

Figure 18 Effect of particle production rate in the load of TSS. 46 
Figure 19 Effect in TSS load by increasing PPR from 7 to $10 \mathrm{~g} / \mathrm{m}^{2} / \mathrm{d}$........................... 47

Figure 20 TSS load simulated and observed $(2000-2008)$, UEFPC-Station 17............. 47

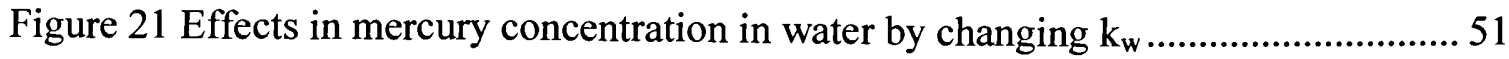

Figure 22 Effect in load of mercury as desorption rate in water changes........................ 51

Figure 23 Effect in load of mercury as TSS load changes..............................................5

Figure 24 Observed and Simulated rainfall, Q, TSS load and Hg load, UEFPC

Station 17, year 2005. Observed values from OREIS database.

Figure 25 Mercury load from outfalls and total at Station 17....................................... 55

Figure 26 Accumulated mercury load from outfalls and total at Station 17 ...................... 55

Figure 27 Simulated load with and without ECOLAB .................................................5 


\section{LIST OF ACRONYMS}

$\begin{array}{ll}\text { DHI } & \text { Danish Hydraulic Institute } \\ \text { EFPC } & \text { East Fork Poplar Creek } \\ \text { EPA } & \text { Environmental Protection Agency } \\ \text { FDC } & \text { Flow Duration Curve } \\ \text { FDI } & \text { Flow Duration Interval } \\ \text { foc } & \text { Fraction Organic Carbon } \\ \text { LDC } & \text { Load Duration Curve } \\ \text { MHL } & \text { Melton Hill Lake } \\ \text { NPDES } & \text { National Pollution Discharge Elimination System } \\ \text { OREIS } & \text { Oak Ridge Environmental Information System } \\ \text { ORNL } & \text { Oak Ridge National Laboratory } \\ \text { ORR } & \text { Oak Ridge Reservation } \\ \text { TMDL } & \text { Total Maximum Daily Load } \\ \text { TSS } & \text { Total Suspended Solids } \\ \text { USGS } & \text { United States Geologic Survey } \\ \text { WCS } & \text { Watershed Characterization System } \\ \text { WEMA } & \text { West End Mercury Area } \\ \text { USLE } & \text { Universal Soil Loss Equation } \\ & \end{array}$




\section{LIST OF VARIABLES}

difv

Diffusion coefficient in water

$\mathrm{dz}$

Thickness of the actual layer in computational grid

dzds

Thickness of diffusion layer in sediment

dzwf

Average thickness water film that metals have to diffuse through

$f_{\text {biot } \cdot \text { difw }}$

Factor for diffusion due to bioturbation

$K_{d}$

Partitioning coefficient for mercury between particulate matter and water

$\mathrm{K}_{\mathrm{ds}}$

Partitioning coefficient for mercury between sediment and pore water

ks

Desorption rate in sediment

$k_{a}$

Adsorption rate $\left[\mathrm{d}^{-1}\right]$

$k_{w}$

Desorption rate $\left[\mathrm{d}^{-1}\right]$

por $_{\text {s }}$

Porosity of sediment

$\mathrm{S}_{\mathrm{HM}}$

Dissolved Mercury Concentration in Water

$\mathrm{S}_{\mathrm{HMS}}$

Dissolved mercury concentration in sediment pore water

$\mathrm{X}_{\mathrm{HM}}$

Adsorbed mercury concentration in water

$\mathrm{X}_{\mathrm{HMS}}$

Adsorbed mercury concentration in sediment

$\mathrm{X}_{\mathrm{SED}}$

Mass of sediment

Vs

Settling velocity $[\mathrm{m} / \mathrm{d}]$

Vc

Critical current velocity for initiation of the movement $[\mathrm{m} / \mathrm{s}]$

RR

Resuspension rate $\left[\mathrm{g} / \mathrm{m}^{2} . \mathrm{d}\right]$

PPR

Particle production rate $\left[\mathrm{g} / \mathrm{m}^{2} . \mathrm{d}\right]$ 


\section{INTRODUCTION}

During the early years of development and production of nuclear weapons, the Y-12 Plant at the Oak Ridge Reservation, TN, released more than 100 metric tons of elemental mercury directly into the East Fork Poplar Creek (EFPC) (Turner and Southworth 1999). The major releases of mercury into the creek stopped in 1963 when the use of mercury in processes within the Oak Ridge Reservation (ORR) was terminated. However, mercury pollution continued spreading into the watershed and the creek. The elemental mercury dissolves and under typical environmental conditions becomes oxidized to mercuric ion which has considerably greater solubility and affinity for complexing with natural organic matter. Mercury complexation significantly increases the mobility of mercury within the watershed and its surface (overland and river flow) and subsurface subdomains (saturated and unsaturated zones). The availability of mercury in the EFPC has created the potential for high levels of methylmercury in the creek biota.

During flood events, higher than expected concentrations of mercury have been reported. Higher levels of suspended solids have been observed as well (DOE 1998). As a result of higher volumes of water and higher velocities in the stream, particle bound mercury in bed sediments is brought to the water column by the resuspended particles. Consequently, the sediment bed of the creek serves as a continuous source of mercury to the water column.

The factors affecting the fate and transport of mercury in the creek are related to the high affinity of mercury to sorb to the organic component of the sediments and suspended solids (Parkpoin et al., 2001, Yin et al., 1997, Liao et al., 2009). The suspended solids 
and the sorbed mercury are mobilized during stormwater events, which increase the mercury concentration downstream (DOE 1998, TDEC 2008).

The exchange of dissolved mercury between the water column and sediment pore water occurs by diffusion driven by the differences in concentrations. Another dynamic process that occurs in the water and in the sediment is the exchange of mercury between dissolved and adsorbed phases by the processes of adsorption-desorption.

Results from sediment samples collected at the UEFPC showed a relationship between mercury concentration and sediment size. Coarser sand particles (1-2mm) presented lower concentrations of mercury $(18-180 \mathrm{mg} / \mathrm{kg}$ ) than smaller particles (clay sizes, $<5 \mu \mathrm{m}$ ) which had concentrations ranging from 125 to $1700 \mathrm{mg} / \mathrm{kg}$ (DOE 1998). This fact narrowed the focus of the study to the suspended solids rather than to the bed load.

Previous modeling efforts for the Upper East Fork Poplar Creek have not included the results of the diffusive transport between the water column and sediment pore water, or the adsorption-desorption processes between dissolved mercury and suspended matter in the water column as part of the total mercury concentration. Those processes are major components of the model presented in this study.

In this Thesis, the results are described by load duration curves which better reflects the correlation between suspended solids, mercury concentration flow rates in the creek.

\section{BACKGROUND}

Several studies have used computer modeling to highlight the importance of sediments and suspended matter in the fate and transport of contaminants in the aquatic 
environment. The North Carolina Department of Natural Resources estimated that eroded sediments were the source of about $75 \%$ of the total mercury load in the Cashie River Watershed (DENR 2004). At Lahontan Reservoir in southwestern Nevada (USA), $90 \%$ of the mercury that entered the system was retained by sediments and kept as a continuous source of pollution (Gandhi et al. 2007). At the White Oak Creek watershed in Tennessee, the major source of cesium-137 (a contaminant that tends to bind to suspended solids) in surface water was channel bed sediments (Bao 1999).

Different computer model approaches have been used to study the effects of sediment as a source of contaminants. Bao (1999) developed a sediment transport study using a hydrological simulation program in Fortran, for cesium-137 at the White Oak Creek watershed in Tennessee. The US Environmental Protection Agency used the IEM-2M model to estimate mercury concentrations, dissolved and particle-bound, in the water column and in bed sediments (USEPA 1997), mass balance equations accounted for the sources of mercury loadings (runoff, soil erosion and diffusive transport from the atmosphere), as well as for sinks (burial in bed sediments, volatilization, and advection out of the water body). At the Cashie River Watershed and other Georgia rivers, a combination of the Watershed Characterization System (WCS) developed by Tetra Tech, and the WASP-TOXI computer model were used to support the development of total maximum daily loads (DENR 2004). At the Lahontan Reservoir in southwestern Nevada, a kinetic speciation mercury transport computer model, BIOTRANSPEC, was developed based on mass balance calculations, the model simulates dissolved, colloidal and particulate mercury concentrations in the water-sediment interface (Gandhi et al. 2007). 
Kubawara et al. (2002) developed a mercury flux (internal recycling) study for the bottom sediment-water column interface in the Lahontan Reservoir, Nevada. The objective of this study was to measure the benthic flux of dissolved mercury and methyl mercury. The results showed that the interaction occurs both ways, with dissolved mercury moving into the water column from the sediment (positive flux) or moving out of the water column into the sediment (negative flux). In addition, the rate at which this process occurs depended on the concentration gradients of other chemicals present in the interfaces.

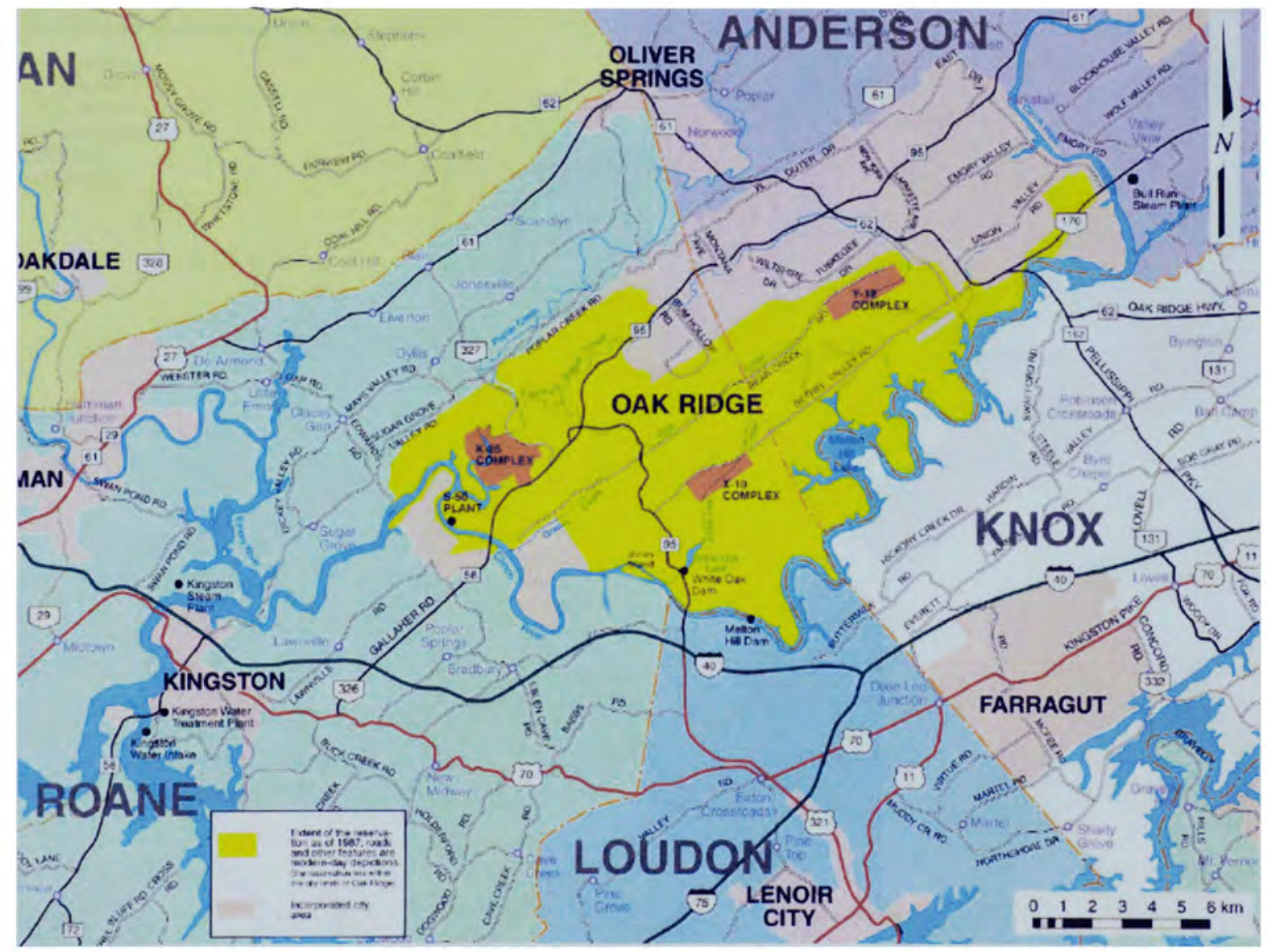

Figure 1 Oak Ridge Reservation 
These studies highlight the importance of the effects of adsorption-desorption processes in the fate and transport of contaminants like mercury that have a tendency to sorb to soils (in the floodplain or in the sediment bed).

The Upper East Fork Poplar Creek (UEFPC), object of the present study, is located within the Oak Ridge Reservation (ORR) in the state of Tennessee, in the counties of Roane and Anderson. The reservation encompasses an area of about 14,260 ha, and has three major US Department of Energy facilities: the Y-12 National Security Complex, the East Tennessee Technology Park (ETTP) or K-25 complex, and the Oak Ridge National Laboratory (Figure 1).

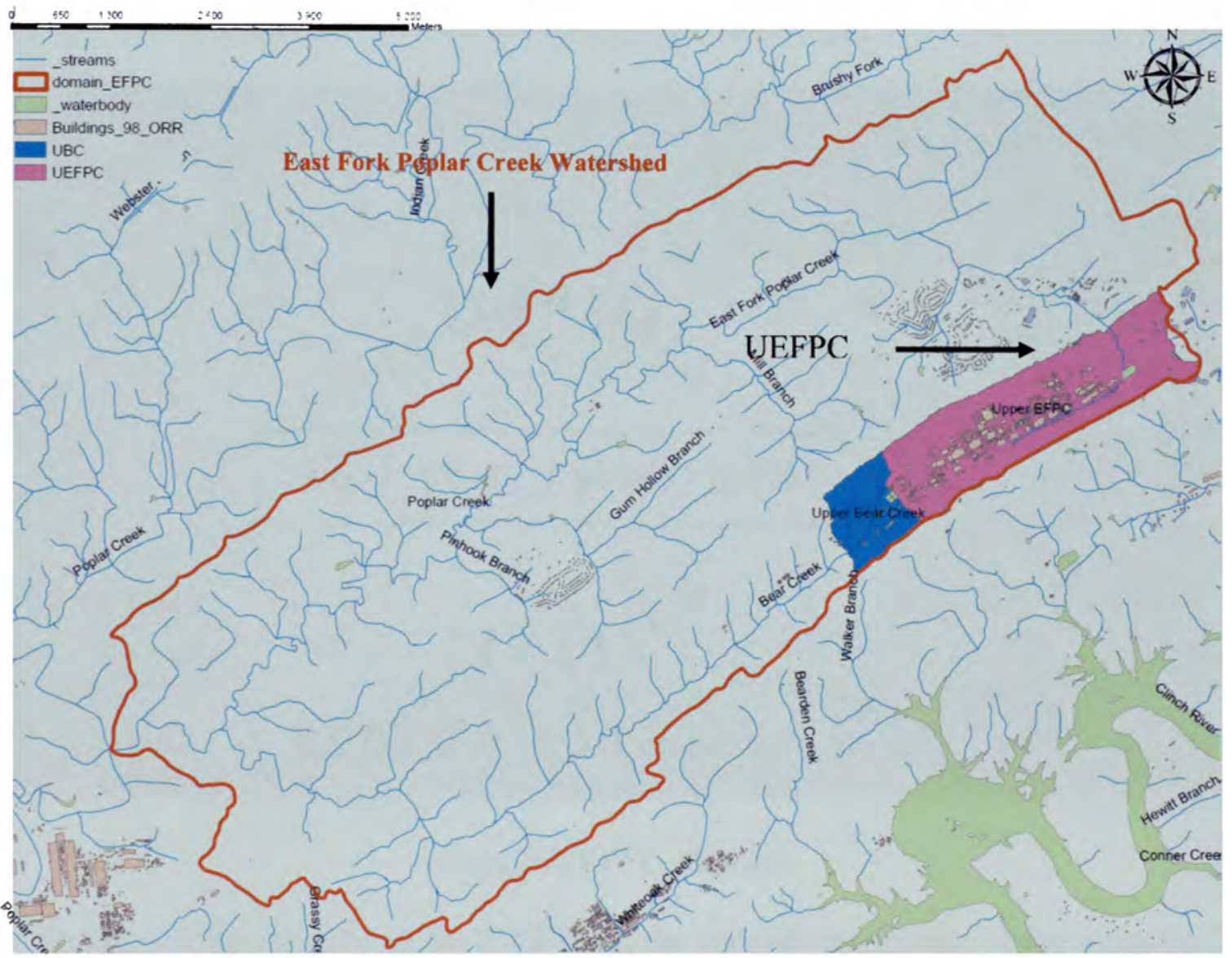

Figure 2 UEFPC watershed 
The UEFPC is defined as the upper waters of the East Fork Poplar Creek (Figure 2); the basin is a sub-watershed of the Lower Clinch River and has a drainage area of 4.73 $\mathrm{km}^{2}$, approximately $68 \%$ from the industrialized areas of the Y-12 Plant. Its boundaries are at the top of Pine Ridge to the north, the top of Chestnut Ridge to the south, the Bear Creek Watershed to the west, and the eastern boundary of the ORR along Scarboro Road to the east.

The creek length is approximately $2.6 \mathrm{~km}$, and runs from the emerging point at the North-South pipe to Station 17 (Figure 3), which is the point where the creek leaves the ORR boundary and becomes the Lower East Fork Poplar Creek. Elevation varies from 283 to $271 \mathrm{~m}$, a gradient of 0.0046 , or $4.6 \mathrm{~m} / \mathrm{km}$ (Moran 1996).

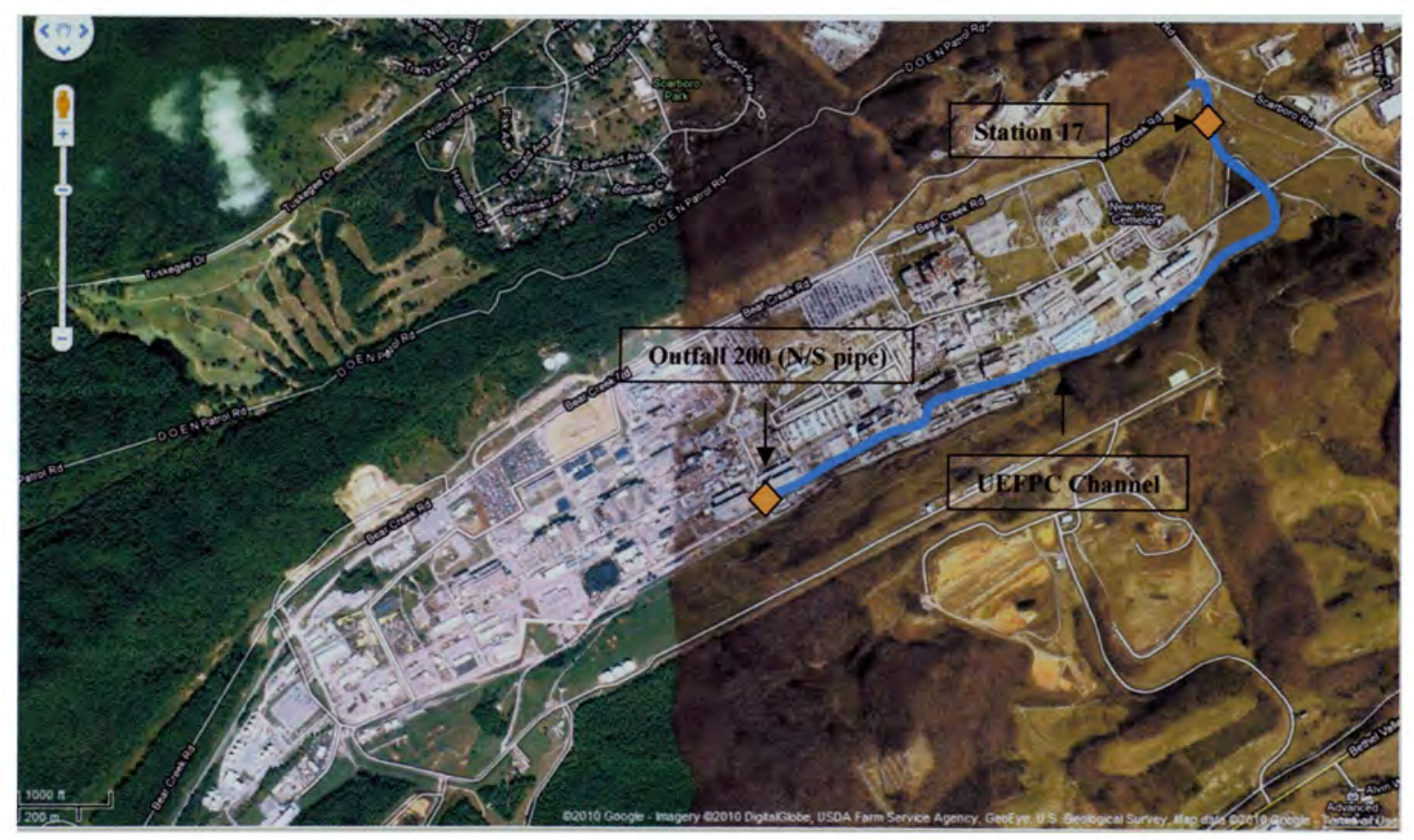

Figure 3 UEFPC channel

During the construction of the Y-12 Plant, the original topography of the watershed was altered. Tributaries and part of the west and central main UEFPC channel were 
covered with fill materials, with depths of up to $30 \mathrm{ft}$, and the creek was captured in a subsurface drainage system.

The upper waters of the stream are composed of discharge from Outfall 200, which drains the West End Mercury Area (WEMA), and water redirected from Melton Hill Lake (MHL), which is added to the creek $6 \mathrm{~m}$ downstream from Outfall 200 as part of the flow management program. The flow management program started in August 1996, for the purposes of maintaining the base flow required by the National Pollution Discharge Elimination System (NPDES), returning the creek to the original flow levels from the 1980 s, preserving the wildlife habitat, and reducing the mercury concentration in the water passing Station 17 by dilution (Southworth et al., 2009).

Under base flow conditions, as measured in February $2009,80 \%$ of the total flow is originated from MHL and 20\% from the industrial waters of the outfall 200 (Miller et al., 2009). The flow management program adds continuously to the creek water at a flow rate of about $0.2 \mathrm{~m}^{3} / \mathrm{s}$ (OREIS database); the contribution of total suspended solids to the stream by the raw water is between $5-10 \mathrm{mg} / \mathrm{L}$ (OREIS database).

\section{RESEARCH HYPOTHESIS AND OBJECTIVES}

The principal objective of this study is to understand and quantify the variables affecting the processes of adsorption-desorption of mercury with suspended particles, the sedimentation and resuspension of the sorbed mercury, and the diffusive transport of dissolved mercury that takes place between the sediment and water phases, under the conditions present at the UEFPC. 
The research hypothesis is that higher levels of mercury concentrations observed at UEFPC Station 17 during high flow events are a result of non-point sources that include the resuspension of smaller particles into the water column and the increased mobility of mercury-contaminated suspended solid loads.

The present study took the described dynamics into account, adding to the existent flow and transport model for the UEFPC, the exchange of mercury between sediment bed and water column, which improved the simulation of mercury concentrations in the creek when compared with the previous model, which only included the transport of mercury by advection dispersion.

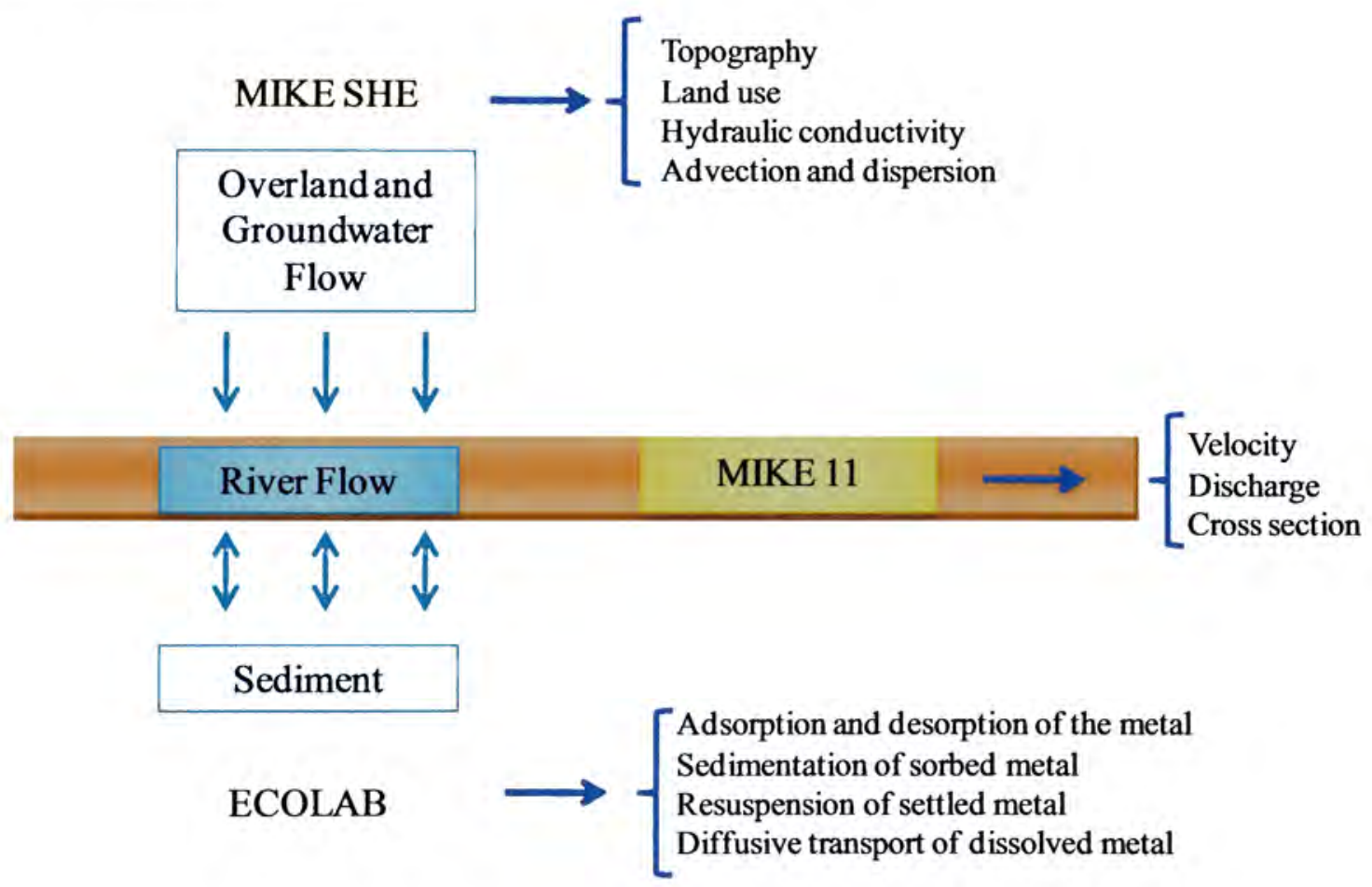

Figure 4 MIKE SHE, MIKE11 and ECOLAB

ECOLAB was used to simulate the fate and transport of mercury at the water and sediment interface for the UEFPC. ECOLAB is a numerical model supported by the 
Danish Hydraulic Institute (DHI) that can be coupled with MIKE SHE and MIKE 11 software, where the hydrodynamics and advection dispersion calculations are carried out

(Figure 4). The model allows for the simulation of physical and chemical dynamics of heavy metals interacting with sediments in the water body. One of the model's advantages over previous models is that it can estimate dissolved and particulate mercury in the water column and in sediments (DHI 2009).

\section{RESEARCH METHODOLOGY}

The integrated flow and transport model couples the hydrological and sediment transport processes (including the interactions between sediment particles, mercury species and water).

\subsection{Sediment transport}

The rate of transport and distribution of sediment in river channels has important implications in the determination of the quality of the water and in the understanding of the fate and transport of contaminants.

The transport of sediments is a process driven by gravity and drag forces between the particles and the fluid, and turbulence in the water stream. It depends on fluid and sediment properties, and characteristics of the sediment bed. The total sediment load carried by a stream can be divided into bed load, suspended load and dissolved load (wash load).

Bed load describes the particles that are transported along or close to the bed of the stream. In general, the movement occurs by rolling, sliding, traction, saltation, and collision between particles and with the bed. Particles will be rolling and sliding in 
continuous contact with the bed, for conditions with bed shear velocity slightly higher than the critical value for initiation of motion. For higher values of bed shear velocity, saltation will occur.

Once a particle is lifted up by the flow and, if the turbulence level is high enough, the particle will travel as part of the suspended load, in which case the bed shear velocity overcomes the fall velocity of the particle. Under this approach, the bed load transport is dominated by gravity forces, while the suspended load is dominated by turbulent eddies (Van Rijn L., 1984).

Suspended load is composed of the particles transported in suspension, with velocity almost equal to the velocity of the water. The movement in this case is controlled by the physical properties of the material and by the dynamics of the velocity field. Particles traveling in suspension are then influenced by two main actions, one causing the resuspension as a result of the upward and downward velocity components of the turbulent eddies, and a second one, the gravitational action, which causes the settling of the particles (Garde \& Tanga Raju., 1985). Fine particles like clays and silts are carried in suspension and tend to move with the flow, carrying adsorbed contaminants downstream.

The present study focuses on the total suspended solids (TSS) which are part of the suspended load. The main difference between the two is based in the diameters of particles that each parameter includes. The suspended load concentration is measured from the whole sample, according to the American Society for Testing and Materials' method (designation: D 3977-97), and incorporates coarser particles. The TSS concentration is measured from a sub-sample, according to Method 160.2 (USEPA, 1999), and excludes the coarser solids in the influent due to settling. Guo (2006) showed 
a good correlation between TSS and suspended load concentration for particles up to $0.1 \mathrm{~mm}$, which corresponds to very fine sands, silts and clays.

The total suspended solids concentration in the water is expressed in terms of dry weight per unit volume (i.e., $\mathrm{mg} / \mathrm{l}$ ), and is quantified by filtering a known volume of water through a weighed standard glass-fiber filter, and then drying the residue retained on the filter to a constant weight at $103-105^{\circ} \mathrm{C}$ (USEPA, 1999).

TSS incorporates material like silt and clay, decaying plants, industrial wastes, and sewage. In general, levels and sizes of suspended particles transported by a stream are affected by changes in the flow rate. More particles and of higher sizes are carried when the flow rate increases due to resuspension of particulate matter from the stream bed generated by the increase in the current' speed (Chapra, 1997).

\subsection{Transport and fate of mercury in the water environment}

Mercury can be found in the environment in the form of gas (elemental mercury), as ionic mercury, and as organic mercury or methyl mercury $(\mathrm{MeHg})$. Its behavior depends on the oxidation state, which varies between metallic $\left(\mathrm{Hg}^{0}\right)$, mercurous $\left(\mathrm{Hg}_{2}{ }^{2+}\right)$, and mercuric $\left(\mathrm{Hg}^{2+}\right)$ (Nriagu 1979).

Elemental mercury $\left(\mathrm{Hg}^{0}\right)$ is a volatile metal with low viscosity, high surface tension and is mobile, liquid at ambient temperatures, and practically insoluble in water. $\mathrm{Hg}^{0}$ oxidizes mainly in the presence of ozone, and also with other oxidants including $\mathrm{HClO}$, $\mathrm{HSO}_{3}{ }^{-}$, and $\mathrm{OH}^{+}$. In the atmosphere, $\mathrm{Hg}^{0}$ is the most common form of mercury (Morel et al., 1998). In natural waters it is generally bound to chloride, sulfide, or organic acids.

Methyl mercury is soluble in water and can be formed from inorganic mercury by microbial processes in soils, sediments, and water, a process known as methylation. The 
reverse process, demethylation, is also possible, in which case $\mathrm{MeHg}$ is reduced to $\mathrm{Hg}^{0}$ and is reintroduced to the atmosphere. Due to its affinity for sulfhydryl groups of proteins, $\mathrm{MeHg}$ is rapidly absorbed by living organisms, and since the rate of absorption is much higher than the elimination rate, it can accumulate for years (Kaleri, 2000, p. 3).

In soils, sediments and surface waters, mercury is most commonly found as inorganic mercuric salts and organomercurics, the most frequent compounds being the mercuric salts $\mathrm{HgCl}_{2}, \mathrm{Hg}(\mathrm{OH})_{2}$ and $\mathrm{HgS}$. Due to the affinity of inorganic mercury for sulfur containing compounds, in soils it tends to form complexes mainly with soil organic matter and, to a lesser extent, to mineral colloids, a process which limits mercury's mobility in the soil.

Mercury can enter freshwater in different forms, organic or inorganic, wet or dry, and from different sources, such as a deposition from the atmosphere, as part of the runoff "bound to suspended soils/humus or attached to dissolved organic carbon" (EPA, 1997, pp. 2-12), or from groundwater as a result of leaching from soil.

In the water column the metal can be partitioned between dissolved and particulatebound phases, being found mainly forming complexes with organic matter, such as being bound to dissolved organic carbon in the dissolved phase, and bound to suspended solids in the particulate phase. Changes in the bacteria and phytoplankton populations in the water body affect the temporal distribution of the metal between those phases (Morel, Kraepiel and Amyot 1998).

Once in the water mercury can be exchanged in three main scenarios. The first, between water and sediment during the sedimentation and/or resuspension of particles. The second, between water and sediment pore water due to differences in concentrations 
resulting in diffusive transport. The third, within water column and within the sediment by processes of adsorption-desorption changing between dissolved and adsorbed phases (DHI, 2009). Honeyman, et al., (1988), summarized the processes occurring with a dissolved heavy metal reacting with a solid phase as follows: adsorption/desorption in the water phase, adsorption/desorption in the sediment phase, sedimentation and resuspension of particulate metal, diffusive transport of dissolved metal, and advection and dispersion.

\section{Water Surface}

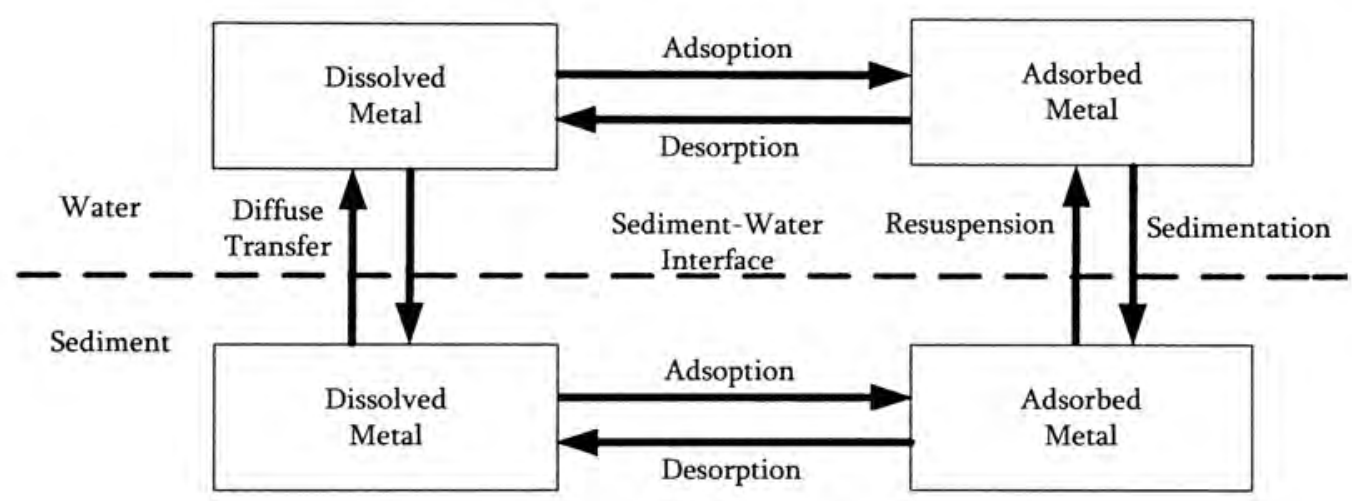

Figure 5 Schematic illustrating the interactions between metal, sediment, and water implemented in ECOLAB and MIKE 11

Adsorption and desorption are processes by which the metal is transferred between solute and solid phases. The extent at which the metal is adsorbed depends on factors like density and acidity of the adsorbent, metal-surface association constants, the presence of 
complexing ligands, type and concentration of particles, particle size, and interactions between particles (Honeyman \& Santschi, 1988).

Diffusion results from movement of particles along concentration gradients. According to Fick's first law the mass flux is proportional to the gradient of concentrations, and goes in the direction of higher to lower concentration (Chapra, 1997, p. 137). When the concentration of dissolved mercury in the water column is lower than that in the sediment pore water, there will be a release of the contaminant into the water.

Advection is the part of the transport that is originated by the motion of the water.

Dispersion is the component of transport that describes local mixing, which results in varying fluid flow velocity (Chapra, 1997, p. 150).

Mercury mobilization and transport within the water creek involves an exchange between the following principal domains:

i) Deposition and resuspension of sediment particles,

ii) Diffusive transfer of mercury species between sediment pore water and creek water,

iii) Adsorption and desorption processes of mercury between sediment particles and sediment pore water,

iv) Adsorption and desorption processes of mercury between suspended sediment particles and creek water.

The ECOLAB water quality model is comprised of four compartments to define mercury's transport processes, which are described in the following sections of the present document. 


\subsubsection{Dissolved mercury in the water $\left(\mathrm{S}_{\mathrm{HM}}\right)$}

Dissolved mercury concentration in water is the result of the relationships between mercury desorbed from suspended solids into the water column, mercury adsorbed by the suspended solids from the water column, and the dissolved mercury exchanged between the water column and the sediment pore water, which is positive (mercury moving into the water column) when the concentration of mercury in the sediment pore water is higher than that in the water column, and negative in the opposite case.

The most important parameters driving this relationship are the partitioning coefficient for mercury between particulate matter and water $\left(\mathrm{K}_{\mathrm{d}}\right)$, and the concentrations of mercury and suspended solids in the water.

$\mathrm{K}_{\mathrm{d}}$ indicates the affinity of the contaminant for the soil phase; therefore, the higher the parameter, the less the metal desorbs from the suspended matter into the water. Since mercury binds to the organic part of the suspended solids, $K_{d}$ in the model is defined from the organic carbon partition coefficient (Equation 18) as mentioned in section 4.2.1, which explains the importance of the level of organic matter in the suspended solids (foc). Higher organic carbon content in the sediment, promotes the adsorption of the metal to the suspended solids.

Dissolved mercury is calculated from the following relationship (DHI, 2009):

$$
\frac{d s_{H M}}{d t}=-a d s s+d e s s+d i f v \quad\left[\frac{g H g}{m^{3} b u l k . d}\right]
$$

Where: adss is the adsorption, dess is the desorption, and difv is the diffusion.

With adsorption calculated from the following formula. Where: $\mathrm{S}_{\mathrm{HM}}$ is the dissolved mercury concentration in the water $\left[\mathrm{g} \mathrm{Hg} / \mathrm{m}^{3} \mathrm{H}_{2} \mathrm{O}\right.$ ], TSS is the suspended solids concentration in the water $\left[\mathrm{g} \mathrm{DW} / \mathrm{m}^{3}\right.$ bulk], $\mathrm{k}_{\mathrm{W}}$ is desorption rate in water $\left[\mathrm{d}^{-1}\right]$, and $\mathrm{K}_{\mathrm{d}}$ is 
the partitioning coefficient for mercury between particulate matter and water $\left[\mathrm{m}^{3}\right.$ $\left.\mathrm{H}_{2} \mathrm{O} / \mathrm{gDW}\right]$.

$$
\text { Adsorption }=k_{w} \cdot K_{d} \cdot S_{H M} \cdot T S S\left[\frac{g H g}{m^{3} \text { bulk.d }}\right]
$$

Desorption is calculated from the following expression. Where: $k_{w}$ is the desorption rate in water $\left[\mathrm{d}^{-1}\right]$ and $\mathrm{X}_{\mathrm{HM}}$ is the adsorbed mercury concentration in the water $\left[\mathrm{gHg} / \mathrm{m}^{3}\right.$ Bulk].

$$
\text { Desorption }=k_{w} \cdot X_{H M} \quad\left[\frac{g H g}{m^{3} \text { bulk.d }}\right]
$$

The diffusive transfer is the transport across the water and sediment interfaces; it occurs due to the difference between solute concentrations in the water column with respect to the concentrations in the sediment pore waters.

In ECOLAB the diffusion is calculated from the following relationship, which is based on Fick's law.

$$
\operatorname{dif} v=\frac{\text { fbiot.difw. }\left(\frac{S_{H M S}}{\text { pors.dzds }}-S_{H M}\right)}{(d z w f+d z d s) \cdot d z} \quad\left[\frac{g H g}{m^{3} \text { bulk.d }}\right]
$$

Where: difv is the diffusion coefficient in water, estimated from the metal's mole weight $\left[\mathrm{m}^{2} / \mathrm{d}\right]$; f $\mathrm{f}_{\text {biot-difw }}$ is the factor for diffusion due to bioturbation [dimensionless], assumed 1 for the model; $\mathrm{S}_{\mathrm{HMS}}$ is the dissolved heavy metal concentration in sediment porewater $\left[\mathrm{g} \mathrm{Hg} / \mathrm{m}^{2}\right] ; \mathrm{S}_{\mathrm{HM}}$ is dissolved heavy metal concentration in the water $\left[\mathrm{g} \mathrm{Hg} / \mathrm{m}^{3}\right.$ bulk] $\approx\left[\mathrm{g} \mathrm{Hg} / \mathrm{m}^{3} \mathrm{H}_{2} \mathrm{O}\right] ; \mathrm{dzwf}$ is the average thickness water film that metals have to diffuse through, default value of $0.1 \mathrm{~mm}$; dzds is the thickness of diffusion layer in sediment [m], calculated by the model from a built-in function; and $\mathrm{dz}$ is the thickness of the actual layer in the computational grid [m], which is calculated by MIKE11. 


\subsubsection{Adsorbed mercury concentration on suspended matter (XHM)}

The adsorbed mercury concentration in the water column (particulate mercury) is the result of mercury adsorbed by the suspended solids present in the water column, and mercury adsorbed to the particles that are resuspended from the river bed (increasing the concentration) minus mercury desorbed from suspended solids into the water column and mercury adsorbed to particles settling (decreasing the concentration). ECOLAB defines the adsorbed mercury concentration on suspended matter as follows (DHI 2009),

$$
\frac{d X_{H M}}{d t}=a d s s-d e s s-\operatorname{sev}+\operatorname{resv} \quad\left[\frac{g H g}{m^{3} \text { bulk.d }}\right]
$$

Where: adss is adsorption defined from equation (2), dess is desorption defined by equation (3), sev is sedimentation, and resv is resuspension.

Sedimentation defined as follows,

$$
\operatorname{sev}=\frac{v_{s} \cdot X_{H M}}{d z} \quad\left[\frac{g H g}{m^{3} \text { bulk.d }}\right]
$$

Where: $v_{s}$ is the settling velocity of suspended solids $[\mathrm{m} / \mathrm{d}], X_{H M}$ is the adsorbed mercury concentration in the water $\left[\mathrm{g} \mathrm{Hg} / \mathrm{m}^{3}\right.$ bulk], and $\mathrm{dz}$ is the thickness of the actual layer in the computational grid [m] calculated by MIKE11.

Assuming that the current speed is higher than the critical value for initiation of the movement (see section 5.1.2), Resuspension (res) is determined from the following relationship (DHI 2009). Where: $R R$ is the resuspension rate $\left[\mathrm{gDW} / \mathrm{m}^{2} / \mathrm{d}\right]$, which is a constant, subject to calibration, $\mathrm{X}_{\mathrm{HMS}}$ is the adsorbed mercury concentration in the sediment $\left[\mathrm{g} \mathrm{Hg} / \mathrm{m}^{2}\right], \mathrm{X}_{\mathrm{SED}}$ is the mass of sediment $\left[\mathrm{g} \mathrm{DW} / \mathrm{m}^{2}\right]$, and $\mathrm{dz}$ is the thickness of the actual layer in the computational grid [m] calculated by MIKE 11.

$$
\text { res }=\frac{R R \cdot \frac{X_{H M S}}{X_{S E D}}}{d z} \quad\left[\frac{g H g}{m^{3} \text { bulk.d }}\right]
$$




\subsubsection{Dissolved mercury in the sediment pore water $\left(\mathrm{S}_{\mathrm{HMS}}\right)$}

Mercury dissolved in the pore water is the result of the balance between mercury desorbed from the sediments in the river bed minus the contaminants adsorbed from the sediment pore water onto the sediments, and the result of the diffusive transport between dissolved mercury in the water column and dissolved mercury in the sediment pore water, as can be seen in the following relationship, and adsorption given by equation (9) (DHI 2009).

$$
\frac{d S_{H M S}}{d t}=-a d s a+d e s a-d i f a \quad\left[\frac{g H g}{m^{2} \cdot d}\right]
$$

With adsorption given by,

$$
a d s a=k_{s} \cdot K_{d s} \cdot S_{H M S} \cdot \frac{X_{S E D}}{d z s . p o r_{s}} \quad\left[\frac{g H g}{m^{2} \cdot d}\right]
$$

Where: $\mathrm{k}_{\mathrm{s}}$ is the desorption rate in sediment $\left[\mathrm{d}^{-1}\right]$ from section $5.2 .2, \mathrm{~K}_{\mathrm{ds}}$ is the partitioning coefficient for metal between particulate matter and water in the sediment $\left[\mathrm{m}^{3} \mathrm{H}_{2} \mathrm{O} / \mathrm{g} \mathrm{DW}\right]$ from section 5.2.1, $\mathrm{S}_{\mathrm{HMS}}$ is the dissolved mercury concentration in the sediment $\left[\mathrm{gHg} / \mathrm{m}^{2}\right]$, dzs is the sediment layer thickness $[\mathrm{m}], \mathrm{X}_{\mathrm{SED}}$ is the mass of the sediment $\left[\mathrm{g} \mathrm{DW} / \mathrm{m}^{2}\right]$ calculated in section 5.1 .3 , and por $_{\mathrm{s}}$ is porosity of the sediment $\left[\mathrm{m}^{3} \mathrm{H}_{2} 0 / \mathrm{m}^{3}\right.$ bulk], assumed as a constant value of 0.4 .

Desorption is given by the following relation, where: $\mathrm{X}_{\mathrm{HM}}$ is the adsorbed mercury concentration in the water $\left[\mathrm{g} \mathrm{Hg} / \mathrm{m}^{3}\right.$ bulk].

$$
\operatorname{des} a=k_{s} . X_{H M S} \quad\left[\frac{g H g}{m^{2} \cdot d}\right]
$$

Also, diffusion is calculated from equation (4). 


\subsubsection{Adsorbed mercury in the sediment $\left(\mathrm{X}_{\mathrm{HMS}}\right)$}

The concentration of mercury sorbed to the sediments in the river bed is calculated in ECOLAB from the following relationship (DHI 2009), which takes into consideration the metal that adsorbs to particles in the sediment, metal that desorbs from sediment and becomes dissolved, the sedimentation and resuspension of mercury contaminated particles.

$$
\frac{d X_{H M S}}{d t}=a d s a-d e s a+s e a-\operatorname{res} a \quad\left[\frac{g H g}{m^{2} \cdot d}\right]
$$

With adsorption determined by,

$$
a d s a=k_{s} \cdot K_{d s} \cdot S_{H M S} \cdot \frac{X_{S E D}}{d z s . p o r_{s}} \quad\left[\frac{g H g}{m^{2} \cdot d}\right]
$$

Where: $k_{s}$ is the desorption rate in sediment $\left[d^{-1}\right]$ see section $5.2 .2, K_{d s}$ is the partitioning coefficient for metal between particulate matter and water $\left[\mathrm{m}^{3} \mathrm{H}_{2} \mathrm{O} / \mathrm{g} \mathrm{DW}\right.$, see section 5.2.1, $\mathrm{S}_{\mathrm{HMS}}$ is the dissolved mercury concentration in the sediment $\left[\mathrm{g} \mathrm{Hg} / \mathrm{m}^{2}\right]$, $d_{z s}$ is the sediment layer thickness [m], $X_{\text {SED }}$ is the mass of sediment $\left[\mathrm{g} \mathrm{DW} / \mathrm{m}^{2}\right]$, and pors is the porosity of sediment $\left[\mathrm{m}^{3} \mathrm{H}_{2} 0 / \mathrm{m}^{3}\right.$ bulk], assumed to be a constant value of 0.4 .

The mass of the sediment is calculated as the difference between sedimentation of particles from the water column, and resuspension of particles from the creek's bed, as shown in equation (13), where: $X_{S E D}$ is the mass of sediment $\left[\mathrm{g} \mathrm{DW} / \mathrm{m}^{2}\right], v_{s}$ is the settling velocity of suspended solids [m/d], a constant subject to calibration; and $R R$ is the resuspension rate $\left[\frac{g D W}{m^{2} \cdot d}\right]$, also a constant subject to calibration.

$$
\frac{d X_{S E D}}{d t}=v_{s} . T S S-R R\left[\frac{g D W}{m^{2} \cdot d}\right]
$$


Sedimentation is defined as the product of settling velocity $[\mathrm{m} / \mathrm{d}]$ and the concentration of mercury adsorbed to suspended particles, $X_{\mathrm{HM}}[\mathrm{g} \mathrm{Hg} / \mathrm{m} 3$ bulk], as presented in the following equation,

$$
\text { sea }=v_{s} \cdot X_{H M} \quad\left[\frac{g H g}{m^{2} \cdot d}\right]
$$

Resuspension, for current velocity exceeding the critical value is given by,

$$
\text { resa }=\frac{R R \cdot X_{X M S}}{X_{S E D}} \quad\left[\frac{g H g}{m^{2} \cdot d}\right]
$$

Where: $R R$ is the resuspension rate of suspended solids $\left[\mathrm{gDW} / \mathrm{m}^{2} / \mathrm{d}\right], X_{X M S}$ is the adsorbed mercury in the sediment $\left[\mathrm{g} \mathrm{Hg} / \mathrm{m}^{2}\right]$, and $X_{S E D}$ is the mass of sediment $[\mathrm{g}$ $\left.\mathrm{DW} / \mathrm{m}^{2}\right]$.

\section{MODEL DEVELOPMENT}

The modeling system consists of coupled MIKE SHE (a 3-dimensional saturated and unsaturated groundwater flow, 2-dimensional overland flow model), MIKE 11 (1dimensional river flow model), and ECOLAB (a 1-dimensional water quality model).

MIKE SHE is a deterministic, physically based and fully distributed hydrological modeling system (Abbott and Refsgaard 1996). It consists of the Water Movement and Water Quality modules. The hydrological processes are described mostly by physical laws (laws of conservation of mass, momentum and energy). The 1-D and 2-D diffusive wave Saint Venant equations describe channel and overland flow, respectively. The Kristensen and Jensen methods are used for evapotranspiration, the 1-D Richards's equation for unsaturated zone flow, and a 3-D Boussinesq equation for saturated zone flow. These partial differential equations are solved by finite difference methods, while other methods (interception, evapotranspiration and snowmelt) in the model are empirical 
equations obtained from independent experimental research (DHI 2008). MIKE 11 is a one-dimensional modeling tool for the detailed analysis, design, management and operation of both simple and complex river and channel systems. The MIKE 11 Hydrodynamic (HD) module solves the depth integrated equations for the conservation of mass and momentum, i.e., the Saint Venant equations (DHI 2008). The HD module is the nucleus of the MIKE 11 modeling system and forms the basis for most modules including Flood Forecasting, Advection-Dispersion, Water Quality and Non-cohesive sediment transport modules.

The present study was developed using ECOLAB, which is the water quality module of the DHI MIKE SHE - MIKE 11. The module has the capability of estimating dissolved and particulate mercury in the water column and in sediments. The module allows the selection of the integration method for the differential equations among Euler, Runge Kutta $4^{\text {th }}$ order and Runge Kutta $5^{\text {th }}$ order. It also requires the specification of the update frequency, which defines how often the ECOLAB processes are calculated in the simulation. These two parameters define the precision and the CPU time necessary to run simulations (DHI 2009b).

The ECOLAB template defined for the present study contains six state variables, sixteen constants, and three forcing variables, in addition to auxiliary variables and processes. The state variables (Table 1) are defined by the system of differential equations, the variables in the sediment have a fixed spatial position and variables in the water column are subject to transport by advection dispersion (AD) from MIKE11. The constants are parameters given to the model that are constant in time, some of them are calculated in the hydrodynamic model, while other constants have assigned default or 
measured values (e.g., mole weight of mercury, density of dry sediment, porosity of the sediment), and some were subject to calibration (e.g., organic-carbon partition coefficient, desorption rate in water, desorption rate in sediment, fraction of organic carbon in suspended solids and fraction of organic carbon in sediment).

Table 1 ECOLAB state variables

\begin{tabular}{|l|c|c|}
\hline \multicolumn{1}{|c}{ Variable } & Transport & Units \\
\hline Dissolved mercury in water column & AD & $\mathrm{mg} / \mathrm{l}$ \\
\hline Adsorbed mercury in water column & AD & $\mathrm{mg} / \mathrm{l}$ \\
\hline Dissolved mercury in sediment & No transport & $\mathrm{g} / \mathrm{m}^{2}$ \\
\hline Adsorbed mercury in sediment & No transport & $\mathrm{g} / \mathrm{m}^{2}$ \\
\hline Suspended solids & $\mathrm{AD}$ & $\mathrm{mg} / \mathrm{l}$ \\
\hline Mass of sediment & No transport & $\mathrm{g} / \mathrm{m}^{2}$ \\
\hline
\end{tabular}

The forcings are external factors that influence the system and are calculated in the hydrodynamic model (e.g., thickness of the actual layer in the computational grid, total water depth, and current speed).

Auxiliary variables and processes serve as arguments for the equations describing the state variables.

\subsection{Parameters affecting suspended solids transport in ECOLAB}

Four main parameters define the total suspended solids (TSS) concentration: settling velocity $\left(v_{s}\right)$, critical current velocity for initiation of the movement $\left(v_{c}\right)$, resuspension rate (RR), and particle production rate (PPR). Those parameters are influenced by the level of sediments in the bed $\left(\mathrm{X}_{\mathrm{SED}}\right)$, and the sizes of the material in suspension. 
In ECOLAB the suspended solids concentration is given by the sum of production and resuspension minus the sedimentation rates (DHI 2009),

$$
\frac{d T S S}{d t}=p r_{s s}-s e d_{s s}+\operatorname{res}\left[\frac{g D W}{m^{3} \text { bulk.d }}\right]
$$

The production of particles $\left(\mathrm{pr}_{\mathrm{ss}}\right)$ is calculated as a function of the rate of particle production, which is a fix coefficient, as follows:

$$
p r_{s s}=\frac{\mathrm{PPR}}{\mathrm{dz}} \quad\left[\frac{\mathrm{gDW}}{\mathrm{m}^{3} \text { bulk.d }}\right]
$$

Where: PPR is the particle production rate $\left[\mathrm{gDW} / \mathrm{m}^{2} / \mathrm{d}\right]$, in the present model defined after calibration as $10 \mathrm{~g} / \mathrm{m}^{2} \mathrm{~d}$; and $\mathrm{dz}$ is the thickness of the actual layer in the computational grid [m], a forcing calculated by MIKE11.

Sedimentation $\left(\operatorname{sed}_{s s}\right)$ is calculated based on settling velocity by the following relationship (DHI 2009), which takes into account that the adsorbed mercury will be transported with the suspended solids (DHI, 2009):

$$
\operatorname{sed}_{s s}=\frac{v_{s} \cdot \mathrm{TSS}}{d z} \quad\left[\frac{g D W}{m^{3} \text { bulk.d }}\right]
$$

Where: $v_{s}$ is the settling velocity of suspended solids [m/d], a value of $6 \mathrm{~m} / \mathrm{d}$ was used in the present model as a calibration result and based on section 5.1.1; TSS is the suspended solids concentration in the water $\left[\mathrm{g} \mathrm{DW} / \mathrm{m}^{3}\right.$ bulk]; and $\mathrm{dz}$ is the thickness of the actual layer in computational grid [m], calculated by MIKE11.

Resuspension (res) is determined from the following relationship (DHI 2009), assuming that the current speed is higher than the critical value for initiation of the movement, calculated in section 5.1.2,

$$
\text { res }=\frac{R R}{d z} \quad\left[\frac{g D W}{m^{3} \text { bulk.d }}\right]
$$


Where: $R R$ is the resuspension rate $\left[\mathrm{gDW} / \mathrm{m}^{2} / \mathrm{d}\right]$, in the present model defined as 650 $\mathrm{g} / \mathrm{m}^{2} / \mathrm{d}$; and $d z$ is the thickness of the sediment layer in the computational grid [m].

\subsubsection{Settling velocity $\left(v_{s}\right)$}

Settling velocity reflects a balance between forces causing settling and forces resisting the settling. It varies as a result of changes in the density and in the apparent viscosity (sediment concentration) of the water. For the range of sediment sizes that we are considered in this work, as the concentration of suspended solids in the stream increases, the settling velocity decreases (Garde and Tanga Raju. 1985).

Once a particle enters the flow after being eroded from the floodplain or as a result of direct discharges to the water body, it can travel in suspension or be deposited in the bed. Coarser particles will move in suspension for shorter distances or might move as part of the bed load by sliding, rolling and bouncing. Settling velocity is then determined by characteristics of the water and by properties of the particles.

A characterization of suspended sediments for the EFPC was developed by the Tennessee Valley Authority (TVA), in 1984 (DOE 1986). Surface layer samples were collected along the creek from mile 0.23 (kilometer 0.37 from upstream) to mile 14.31(kilometer 23 from upstream) and then sieved and separated into fractions according to particles sizes of less than $0.0005 \mathrm{~mm}, 0.002 \mathrm{~mm}, 0.008 \mathrm{~mm}, 0.016 \mathrm{~mm}$, $0.062 \mathrm{~mm}, 0.125 \mathrm{~mm}, 0.60 \mathrm{~mm}$ and $2.0 \mathrm{~mm}$ (DOE 1986). Data collected during the study are presented in Table 10 in the appendix section. At the time of the study (1984), about $45 \%$ of the particles just upstream of Station $17(\mathrm{~km} \mathrm{23})$ had a sieve size of $0.062 \mathrm{~mm}$ or less and about $57 \%$ had a sieve size of $0.125 \mathrm{~mm}$ or less. 
Table 2 Settling velocity

\begin{tabular}{|c|c|c|c|}
\hline Sediment & $\begin{array}{l}\text { Particle Size } \\
(\mathbf{m m})\end{array}$ & $\begin{array}{c}\text { Particle Density } \\
\left(\mathrm{g} / \mathrm{cm}^{\mathbf{3}}\right)\end{array}$ & $\begin{array}{l}\text { Settling Velocity } \\
(\mathbf{m} / \mathbf{d})\end{array}$ \\
\hline Coarse Silt & $0.062-0.031$ & 1.8 & $144.81-36.20$ \\
\hline Medium Silt & $0.031-0.016$ & 1.8 & $36.20-9.64$ \\
\hline Fine Silt & $0.016-0.008$ & 1.8 & $9.64-2.41$ \\
\hline Very Fine Silt & $0.008-0.004$ & 1.8 & $2.41-0.60$ \\
\hline
\end{tabular}

Based on these data and using Stokes' equation, the settling velocity is calculated for silt size particles, resulting in variation from 0.6 to $145 \mathrm{~m} / \mathrm{d}$ (Table 2). In the model, a value of $6 \mathrm{~m} / \mathrm{d}$ was used, as per the analysis presented in section 5.7.1.3.

\subsubsection{Critical current velocity for initiation of suspension (Vc)}

When water is flowing in a channel, there are two major forces in action: the force of gravity moving the water down slope, and the force of friction of the water against the bed of the channel, slowing the water down. The interaction of these forces generates a shear stress field $(\tau)$ with higher values near the river bed.

The moment at which a particle is entrained from the bed and is transported in suspension is determined by the critical shear stress $\left(\tau_{\mathrm{cr}}\right)$, which is the stress needed to mobilize a particle from the bed. When the shear stress and the critical shear stress are equal $\left(\tau=\tau_{\mathrm{cr}}\right.$ ), the channel is in equilibrium; if $\tau \gg \tau_{\mathrm{cr}}$, degradation (erosion) of the channel occurs; and if $\tau \ll \tau_{\mathrm{cr}}$, channel aggradation (deposition) will likely result (Vermont Agency of Natural Resources 2009).

In order for a particle to be transported in suspension, the particle's velocity must be exceeded by the vertical component of the turbulent eddies velocity of the stream. Such 
values have been reported to be in the same order of magnitude as the critical bed shear velocity and, for this reason, the critical current velocity for initiation of suspension is often expressed in terms of the critical bed shear velocity (L. Van Rijn 1984b, 1614).

Shields was the first in providing a dimensionless parameter $\left(\tau_{\mathrm{ci}}\right)$ for the critical shear stress, based on specific density (s) of the sediment particles, critical bed shear velocity for initiation of the motion $\left(\mu_{c_{c r}}\right)$, and average particle diameter $\left(D_{50}\right)($ Choi and Kwak 2001).

To calculate the critical current velocity, first, a dimensionless particle parameter $\left(D^{*}\right)$ is calculated from the following equation.

$$
D *=D_{50}\left[\frac{(s-1) g}{v^{2}}\right]^{1 / 3}
$$

Where: $D_{50}$ is the average particle size, $s$ is the specific density (particle density divided by fluid density), $g$ is the acceleration due to gravity $\left(981 \mathrm{~cm} / \mathrm{s}^{2}\right)$, and $v$ is the kinematic viscosity coefficient $\left(0.01 \mathrm{~cm}^{2} / \mathrm{s}\right)$.

Table 3 Shields dimensionless parameters (L. Van Rijn 1984b)

\begin{tabular}{|c|c|}
\hline $\mathbf{D}_{*}$ & $\boldsymbol{\tau}_{\text {cr }}$ \\
\hline$\leq 4$ & $0.24 \times \mathrm{D}^{-1}$ \\
\hline $4<\mathrm{D} * \leq 10$ & $0.14 \times \mathrm{D}^{-0.64}$ \\
\hline $10<\mathrm{D} * \leq 20$ & $0.14 \times \mathrm{D}^{-0.10}$ \\
\hline $20<\mathrm{D} * \leq 150$ & $0.14 \times \mathrm{D}^{0.29}$ \\
\hline $\mathrm{D}_{*}>150$ & 0.055 \\
\hline
\end{tabular}

Then, the critical mobility parameter $\left(\tau_{\mathrm{cr}}\right)$ is read from Shields curve according to the values presented in Table 3 and used in the calculation of the critical shear velocity $\left(\boldsymbol{\mu}_{*, c r}\right)$ from the following equation.

$$
\tau_{c r}=\frac{\left(\mu_{*, c r}\right)^{2}}{(s-1) \cdot g \cdot D_{50}}
$$


Calculated values of critical current velocity varied between $0.01-0.10 \mathrm{~m} / \mathrm{s}$, for ranges of particles $\left(D_{50}\right)$ between $0.004 \mathrm{~mm}$ and $0.125 \mathrm{~mm}$, according to the suspended sediment characterization for the UEFPC presented in Table 10. Particles' specific density $(s)$ is $1.8 \mathrm{~g} / \mathrm{cm}^{3}$ (Levine, Hargrove and Forrest 1995).

In this work, a value of $0.135 \mathrm{~m} / \mathrm{s}$ was used, as per the analysis presented in section 5.7.1.1. The higher value used in the model is justified by the fact that Shields dimensionless parameter does not consider the entrainment of a particle from a bed of non-uniform size material; therefore, it does not account for the force needed to entrain a particle that is surrounded by larger particles is higher than the force needed to move a particle surrounded by smaller particles. This is known as the hiding effect (Andrews 1983). In the case of the EFPC, the bed is made of gravel (Table 11) with particle sizes up to $38 \mathrm{~mm}$.

Table 4 Mass of sediment at Station 17 (Southworth et. al., 2010)

\begin{tabular}{|c|c|c|}
\hline Sample & \multicolumn{1}{c}{$\begin{array}{c}\text { Fines } \\
\mathbf{k g} / \mathbf{m}^{2}\end{array}$} & $\begin{array}{c}\text { Rocks } \\
\mathbf{k g} / \mathbf{m}^{2}\end{array}$ \\
\hline 1 & 85.2 & 196.9 \\
\hline 2 & 23.0 & 152.6 \\
\hline 3 & 7.3 & 158.6 \\
\hline 4 & 36.9 & 103.9 \\
\hline 5 & 45.7 & 259.0 \\
\hline 6 & 15.8 & 152.3 \\
\hline 7 & 111.0 & 204.3 \\
\hline 8 & 54.3 & 270.8 \\
\hline 9 & 305.0 & 89.1 \\
\hline Average & 76.0 & 176.4 \\
\hline
\end{tabular}




\subsubsection{Mass of sediment (XSED)}

Based on data collected by Southworth et al., 2010, the total mass of sediment available to be resuspended, per unit area, at a location close to Station 17 in the EFPC was estimated at an average of $76 \mathrm{~kg} / \mathrm{m}^{2}$ for the fines, and an average of $176 \mathrm{~kg} / \mathrm{m}^{2}$ for gravel (Table 4). In the model simulations, a value of $100 \mathrm{~kg} / \mathrm{m}^{2}$ was used for the mass of sediment available to be resuspended.

\subsubsection{Resuspension rate (RR)}

The resuspension of sediments occurs when the bottom shear stress exceeds the critical sheer stress velocity (DHI 2009). During the resuspension, particles that have been deposited in the bed of the stream are moved to the water column, providing an internal source of mercury. The availability of sediments for resuspension can be limited by the age of the deposits, the amount of particles available and the depth of the creek. The resuspension rate increases in the presence of turbulence in the water body.

In the case of the ECOLAB model, the resuspension rate is a constant parameter, used in the calculation of the sediments resuspended into the water column, therefore affecting the levels of suspended particles in the water column as well as the concentration of particulate mercury in the water.

During the sensitivity analysis, it was determined that this is the parameter that defines the peaks in the concentrations of suspended solids. After several simulations, a value of $650 \mathrm{~g} / \mathrm{m}^{2} / \mathrm{d}$ was used in this thesis.

\subsubsection{Particle production rate (PPR)}

Particle production rate is the variable that simulates the production of particles in the stream due to primary production of algae, and the photosynthesis. Species, composition 
and productivity of algae in natural streams are affected by factors like watershed area, levels of inorganic phosphorous, temperature, discharge, canopy cover, and light availability (Wehr and Sheath 2003).

In open rivers, the algae production is more significant than in highly covered areas due to the availability of light. The periphyton uses sunlight to produce biomass from plant nutrients and dissolved inorganic carbon; this alga grows attached to sediments in the bed, and can be scoured out as a result of higher current velocities or as a result of bioturbation, generating suspended solids in the water column (Hill et. al., 2010).

The effect of levels of microalgae in streams is also extended to the fate and transport of the contaminants due to periphyton's large surface area and sorptive nature, which increases the bioavailability of the contaminant as it is also a source of food for herbivores.

Inputs of inorganic nutrients, like phosphorus and nitrogen, stimulate periphyton growth, in the case of the EFPC, Hill et al. (2010) reported that levels of nutrients were over the boundary for eutrophication. A mean biomass of periphyton (data for years 1998 - 2002) was measured as $15 \mu \mathrm{g} / \mathrm{cm}^{2}$, and the primary productivity rate as an average of $7.5 \mu \mathrm{g} \mathrm{C} / \mathrm{cm}^{2} / \mathrm{h}$, an equivalent to $1.8 \mathrm{~g} \mathrm{C} / \mathrm{m}^{2} / \mathrm{d}$. If the fraction of organic carbon varies between 0.05 and 0.1 (session 5.2.1), then the particle production rate can be estimated in the range of 18 to $36 \mathrm{~g} / \mathrm{m}^{2} / \mathrm{d}$, using the average primary productivity rate, which means that there is a higher range of variation for the calculated PPR.

\subsection{Parameters affecting mercury's fate and transport in ECOLAB}

The main parameters in the ECOLAB module that define the concentrations of mercury in the water and sediment include the partition coefficients (organic carbon 
partition coefficient, soil-water partition coefficient), the fraction of organic carbon present in the suspended solids and sediments, and the desorption rate of mercury in the water and in the sediments.

\subsubsection{Partition coefficients}

Partition coefficients are empirically derived constants, and are use to describe the fate of contaminants in the environment, signifying how the contaminant is distributed among two phases (i.e., liquid to liquid, liquid to solid, two solids) by indicating the affinity of the contaminant for a specific phase (LaGrega, Buckingham and Evans 2001). In the present study, the principal coefficients used are the soil-water partition coefficient $\left(\mathrm{K}_{\mathrm{d}}\right)$, and the organic carbon partition coefficient $\left(\mathrm{K}_{\mathrm{oc}}\right)$.

$\mathrm{K}_{\mathrm{d}}$ describes the tendency of the chemical to be adsorbed by soil or sediment; it is a ratio of metal sorbed to the soil ( $\mathrm{mg}$ of metal $/ \mathrm{kg}$ of soil) to metal dissolved in the liquid media ( $\mathrm{mg}$ of metal/L of solution). High values of $\mathrm{K}_{d}$ indicate affinity of the chemical for soils and, consequently, lower values are indicative of the tendency to stay in solution. Allison et al. (2005), based on an extensive literature review, proposed the partition coefficients presented in Table 5 for inorganic mercury, expressed as $\log K_{d}(L / k g)$.

Table 5 Log $\mathrm{K}_{\mathrm{d}}(\mathrm{L} / \mathrm{kg})$ values for inorganic mercury

\begin{tabular}{|c|c|c|c|c|c|}
\hline Phase & Mean & $\begin{array}{l}\text { Standard } \\
\text { Deviation }\end{array}$ & Minimum & Maximum & Page \\
\hline Soil/soil water & $3.6^{\mathrm{a}}$ & 0.7 & 2.2 & 5.8 & $3-9$ \\
\hline Sediment/pore water & $4.9^{b}$ & 0.6 & 3.8 & 6.0 & $3-12$ \\
\hline Suspend solids/water & $5.3^{\mathrm{c}}$ & 0.4 & 4.2 & 6.9 & 3-15 \\
\hline
\end{tabular}

${ }^{3} 3,981 \mathrm{~L} / \mathrm{kg},{ }^{b} 79,432 \mathrm{~L} / \mathrm{kg}$, and ${ }^{\mathrm{c}} 199,526 \mathrm{~L} / \mathrm{kg}$

Values presented in Table 5, show a strong affinity of inorganic mercury to remain bound to soils, with higher affinity $\left(>K_{d}\right)$ for suspended solids than for sediments. $K_{d}$ for 
a particular stream and metal, will vary depending on the nature of the suspended solids and sediments, $\mathrm{pH}$ of the water, concentration of the metal in the particulate and dissolved phase, and presence and levels of metal complexing agents, among other factors (Honeyman and Santschi 1988). In the case of the EFPC, a value of 1,796.7 L/kg was reported for the phase soil to soil water (DOE 2005).

$\mathrm{K}_{d}$ can be calculated from the following relation (DHI 2009),

$$
K_{d}=f_{o c x} K_{o c}
$$

Where: $f_{o c}$ is the fraction of organic matter and $K_{o c}$ is the organic carbon partition coefficient.

The fraction of organic carbon $\left(f_{o c}\right)$ is a dimensionless parameter that measures grams of organic carbon over grams of soil; therefore, it gives the fraction of organic matter available for adsorbing the organic contaminant. Soils with high organic carbon content will adsorb more of the contaminant, consequently limiting the mobility to the water phase.

Values for $f_{\text {oc }}$ in suspended sediments have been reported in the order of $0.05-0.1$, with a mean of 0.075 , and for soils in the range of $0.002-0.024$, with a mean of 0.01 (USEPA 2008). The USGS (2000) reported $f_{o c}$ in bed sediments in the range of 0.011 to 0.04 , with mean of 0.02 . In the case of the EFPC, $f_{o c}$ for soil was reported in the range of $0.0002-0.014$, with a median of 0.003 (DOE 2005b).

$\mathrm{K}_{\mathrm{oc}}$ is the organic carbon partition coefficient, defined as the concentration of the chemical in the organic carbon component of the soil [ $\mu \mathrm{g}$ adsorbed $/ \mathrm{kg}$ organic $\mathrm{C}$,or $\mathrm{ppb}$ ] divided by the concentration of the chemical in water $[\mu \mathrm{g} / \mathrm{L}]$. High values of $\mathrm{K}_{\mathrm{oc}}$ characterize less mobile organic chemicals. 


\subsubsection{Adsorption/desorption rates from suspended matter and sediments}

The balance between adsorption and desorption processes define the concentration of mercury in the water. These processes are governed by factors like organic matter content of the sediments, $\mathrm{pH}$ of the water, levels of chloride ions, redox potential, and ionic strength (Parkpoin et al., 2001).

In the formulation of ECOLAB, as well as in the literature, the role of organic matter in the sorption kinetics is vital. In general, high organic matter contributes to higher levels of adsorption (Parkpoin et al., 2001, Yin et al., 1997, Liao et al., 2009). Also, the higher the organic carbon content of the soil (suspended mater and sediments), the "higher the fraction of $\mathrm{Hg}(\mathrm{II})$ that is resistant to desorption" (Yin et al., 1997, p.496). This resistance of mercury to desorb from soils might be due to its diffusion within the micropores of the soil particles and to its affinity for sulfur sites.

Adsorption and desorption are reverse reactions that describe the transition, of mercury in this case, between the solute and the solid phases. With adsorption being the forward reaction occurring from the concentration in water to the concentration in soils, and desorption being the reverse reaction (DHI 2009). The partition coefficient $\left(\mathrm{K}_{\mathrm{d}}\right)$ establishes a linear relationship between the concentration of a contaminant in soil and the concentration of that contaminant in water at equilibrium, therefore the adsorption and desorption rates are related to each other by $K_{d}$, as expressed in the equation below.

$$
K_{d}=k_{a} / k_{w}
$$

Where: $k_{a}$ is the adsorption rate $\left[\mathrm{m}^{3} \mathrm{H}_{2} \mathrm{O} / \mathrm{gDW} / \mathrm{d}\right]$ and $k_{w}$ is the desorption rate $\left[\mathrm{d}^{-1}\right]$.

$K_{d}$ is different for suspended solids and sediment (Table 5); therefore, the rates are different. 
The desorption rate of mercury from sediments was reported by Parkpoin et al. (2001) in the range of $0.0006-0.014 / \mathrm{d}$ with a median of $0.004 / \mathrm{d}$, for sediments with $\mathrm{f}_{\mathrm{oc}}$ of 0.02 to 0.03 and more than $50 \%$ clay content. Higher values for this rate correspond to sediments with higher levels of chloride ions (30\%). During the model calibration, the best fit for this parameter was a value of $0.02 / \mathrm{d}$.

\subsection{Model domain}

The model domain defined for this project is the Upper East Fork Poplar Creek watershed, with a drainage area of about of $4.73 \mathrm{~km}^{2}$. Figure 2 presents two subdomains of the East Fork Poplar Creek; the Upper Bear Creek (blue) and the Upper East Fork Poplar Creek (pink).

A total of 22 cross-sections were defined for the UEFPC; Table 13 presents the descriptions for the cross-sections in the chainages $0 \mathrm{~m}$ and $2663 \mathrm{~m}$.

\subsection{Coupling of MIKE SHE and MIKE 11 HD with ECOLAB}

MIKE SHE and MIKE 11 were coupled by defining branches (reaches) where MIKE 11 HD interacts with MIKE SHE. The hydrologic components of MIKE SHE are directly coupled to DHI's river hydraulic program MIKE 11.

The MIKE SHE-MIKE 11 coupling enables one-dimensional simulation of river flows and water levels using the fully dynamic Saint Venant equations; simulation of a wide range of hydraulic control structures; area-inundation modeling; dynamic overland flooding flow to and from the MIKE 11 river network; and full coupling of surface and sub-surface flow processes in MIKE 11 and MIKE SHE.

To simulate the exchange between river and groundwater, an assumption was made that the river is in full contact with the aquifer material. In this case, the only head loss 
between the river and the grid node is that created by the flow from the grid node to the river itself. This is typical of gaining streams, or streams that are fast moving.

Figure 6 shows a typical Mike SHE river cross-section compared to an equivalent Mike $11 \mathrm{HD}$ cross-section. In this case, the conductance, $\mathrm{C}$, between the grid node and the river link is given by:

$$
C=\frac{K \cdot d a \cdot d x}{d s}
$$

Where $K$ is the horizontal hydraulic conductivity in the grid cell, $d a$ is the vertical surface available for exchange flow, $d x$ is the grid size used in the saturated zone component, and $d s$ is the average flow length. The average flow length, $d s$, is the distance from the grid node to the middle of the river bank in the triangular, river-link crosssection. $d s$ is limited to between $1 / 2$ and $1 / 4$ of a cell width, since the maximum river-link width is one cell width (half cell width per side).

The MIKE 11(HD) hydraulic model uses the precise cross-sections, as defined in the MIKE 11 .xns11 (cross-section) file, for calculating the river water levels and the river volumes. However, the exchange of water between MIKE 11 and MIKE SHE is calculated based on the river-link cross-section. The river-link is a simplified, triangular cross-section interpolated (distance weighted) from the two nearest MIKE 11 crosssections. The top width is equal to the distance between the cross-section's left and right bank markers. The elevation of the bottom of the triangle equals the lowest depth of the MIKE 11 cross-section (the elevation of Marker 2 in the cross-section). The left and right bank elevations in MIKE 11 (cross-section markers 1 and 3 in MIKE 11) are used to define the left and right bank elevations of the river link. 


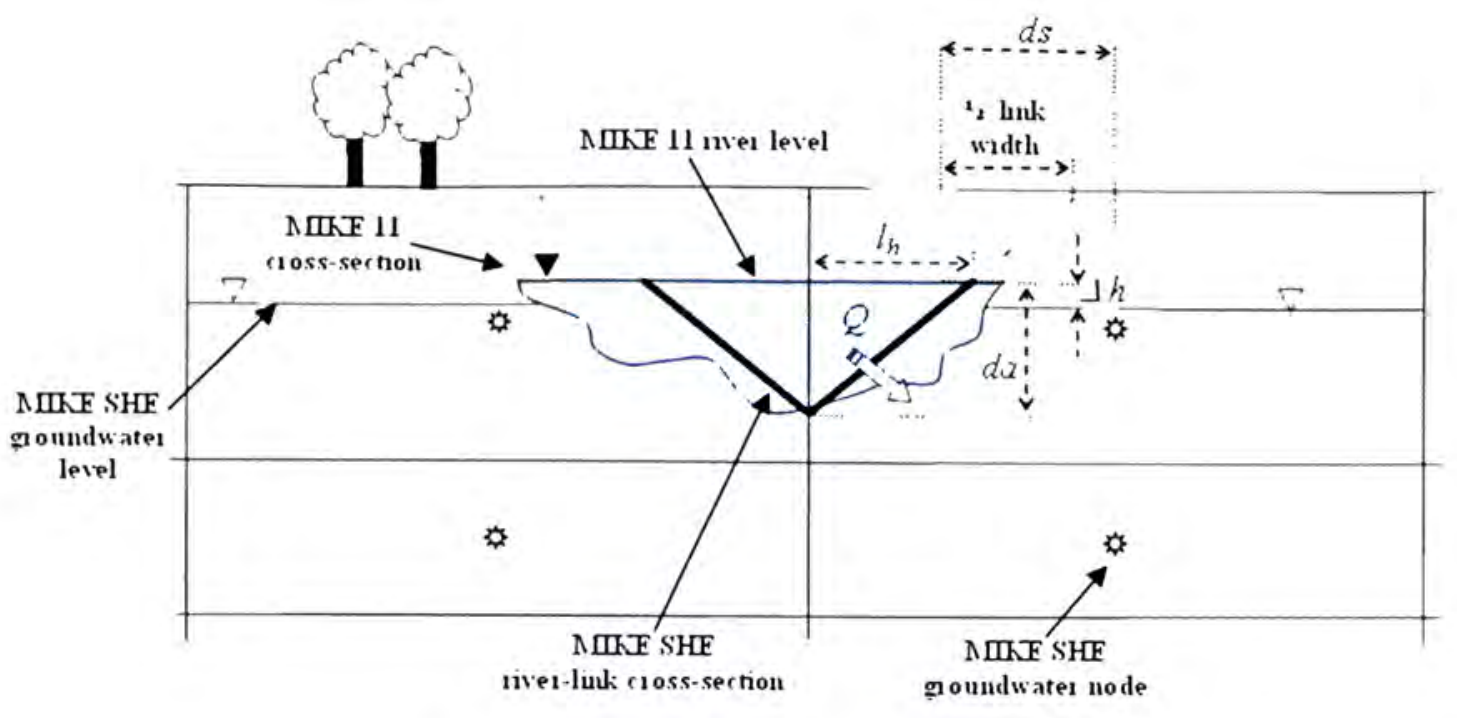

Figure 6 A typical MIKE SHE river link cross-section

\subsection{Boundary conditions}

An Open Boundary was specified assuming free upstream and downstream ends of the model domain. The boundary conditions used in the river model are shown in Table 12. When the Open option is selected in a Boundary Description cell, a branch name and chainage are also needed in order to identify the location of the boundary.

An open boundary condition has two valid boundary types: 1) Inflow, which was specified when a time-varying or constant flow hydrograph condition (for the HD model) is required with or without a solute component (for the $\mathrm{AD}$ model); 2) Q-h was specified when the relationship between the discharge and the water level (HD model) is known and used with or without a solute component (used in the AD model).

\subsection{Conceptual model}

In the ECOLAB module, there are four sub-domains among which mercury is exchanged: dissolved and adsorbed mercury in the water and dissolved and adsorbed mercury in the sediment (Figure 5). 
The concentration of mercury in each sub-domain depends on: 1) the interactions that take place by processes of adsorption and desorption within the water column, and within the sediment phase; 2) the sedimentation and resuspension of small particles, to and from the river bed, bringing mercury contaminated particles into the water column; and 3) the diffusive transport of dissolved mercury between the water column and sediment pore water.

\subsection{Model calibration}

The purpose of model calibration is to define optimum values for the parameters affecting the processes in the system, and implies the need to carry several simulations. Once the calibration parameters are identified, a sensitivity analysis is performed to gain insight into which assumptions are critical, to evaluate the effect on the process under simulation of changes in input parameters, and to determine the importance of each parameter in terms of its effect in the output (USEPA 2009).

For the sensitivity analysis, the input parameters are fixed during a simulation and are changed in different runs. A model parameter can be derived from observed or measured data, a constant that is characteristic of the process or region being modeled (i.e., porosity and density of the sediment), a quantity estimated from the physical formulation of the parameter (i.e., critical current velocity, settling velocity), or an estimated value from literature review (i.e., fraction of organic carbon).

Due to the wide range of variability that usually occurs in stream flows, and in order to effectively calibrate the variables for the model, flow and load duration curves constitute a valid tool for the analysis of data. 
A flow duration curve (FDC) presents a relationship between the frequency and the magnitude of the flow in a particular stream. The daily main flow is presented on the Yaxis in cubic meters per second (cms). On the $\mathrm{X}$-axis is the corresponding percent of time in which that flow value is met or exceeded. To construct it, the daily mean flow data for the given interval, is ranked from largest to smallest and a probability is assigned according to the rank using the following equation (USEPA 2008b).

$$
p_{i}=\frac{i}{n+1}
$$

Where: $p i$ is the exceedance probability, $i$ is the rank number, and $\mathrm{n}$ is the number of observations.

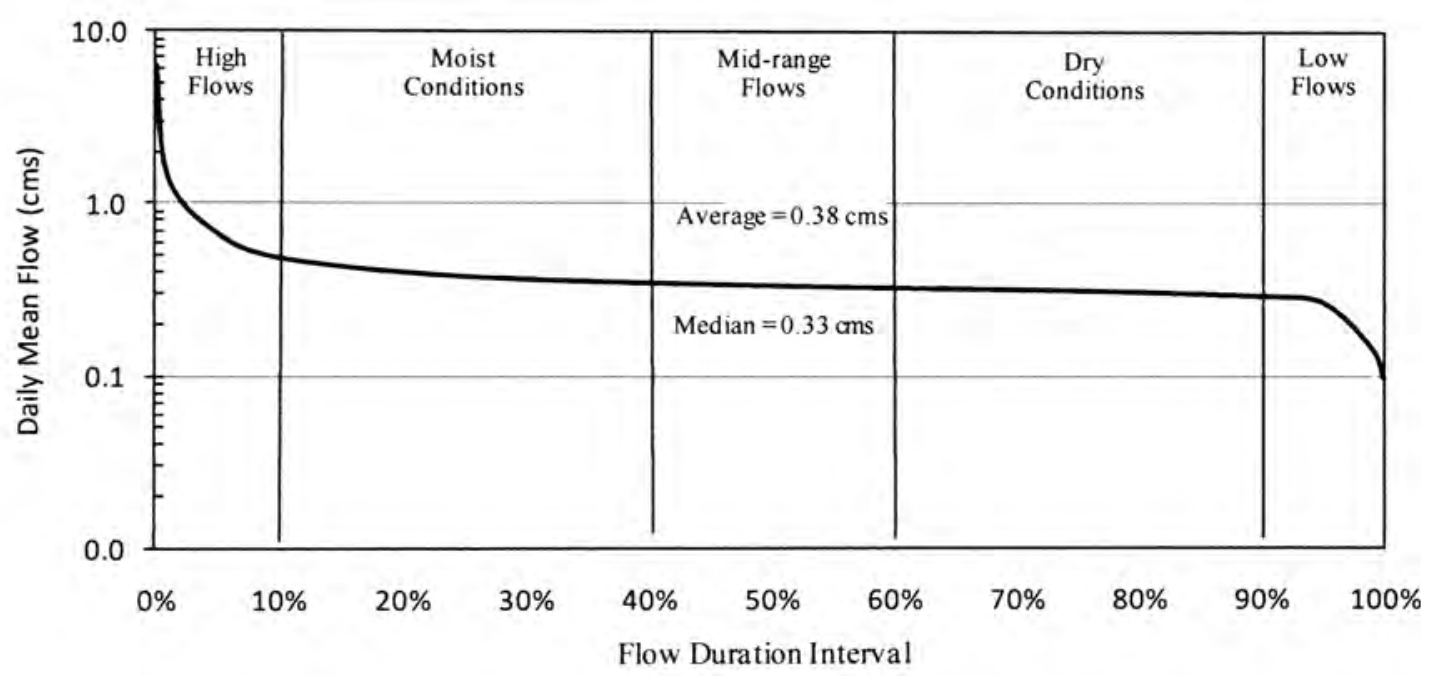

Figure 7 Flow duration curve UEFPC Station 17(data from OREIS database years 1996-2008)

Figure 7 presents a flow duration curve for the UEFPC using observed data from the OREIS database for Station 17 for the years from 1996 to 2008. The highest observed flow value at this station for the studied period is $6.3 \mathrm{cms}$ : the lowest observed flow is 0.1 
$\mathrm{cms}$, and the median flow (the 50 percent FDI) is $0.33 \mathrm{cms}$. Also, there were five levels of flow established according to the flow duration interval.

Table 6 Probabilistic distribution observed flow UEFPC station 17

\begin{tabular}{|c|c|l|}
\hline Probability & Flow(cms) & \multicolumn{1}{|c|}{ Classification } \\
\hline 0.01 & 1.4016 & High flow \\
\hline 0.05 & 0.6658 & High flow \\
\hline 0.10 & 0.4818 & High flow \\
\hline 0.25 & 0.3767 & Moist conditions \\
\hline 0.50 & 0.3329 & Mid-range flow \\
\hline 0.75 & 0.311 & Dry conditions \\
\hline 0.90 & 0.2891 & Dry conditions \\
\hline 0.95 & 0.254 & Low flow \\
\hline 0.99 & 0.1314 & Low flow \\
\hline
\end{tabular}

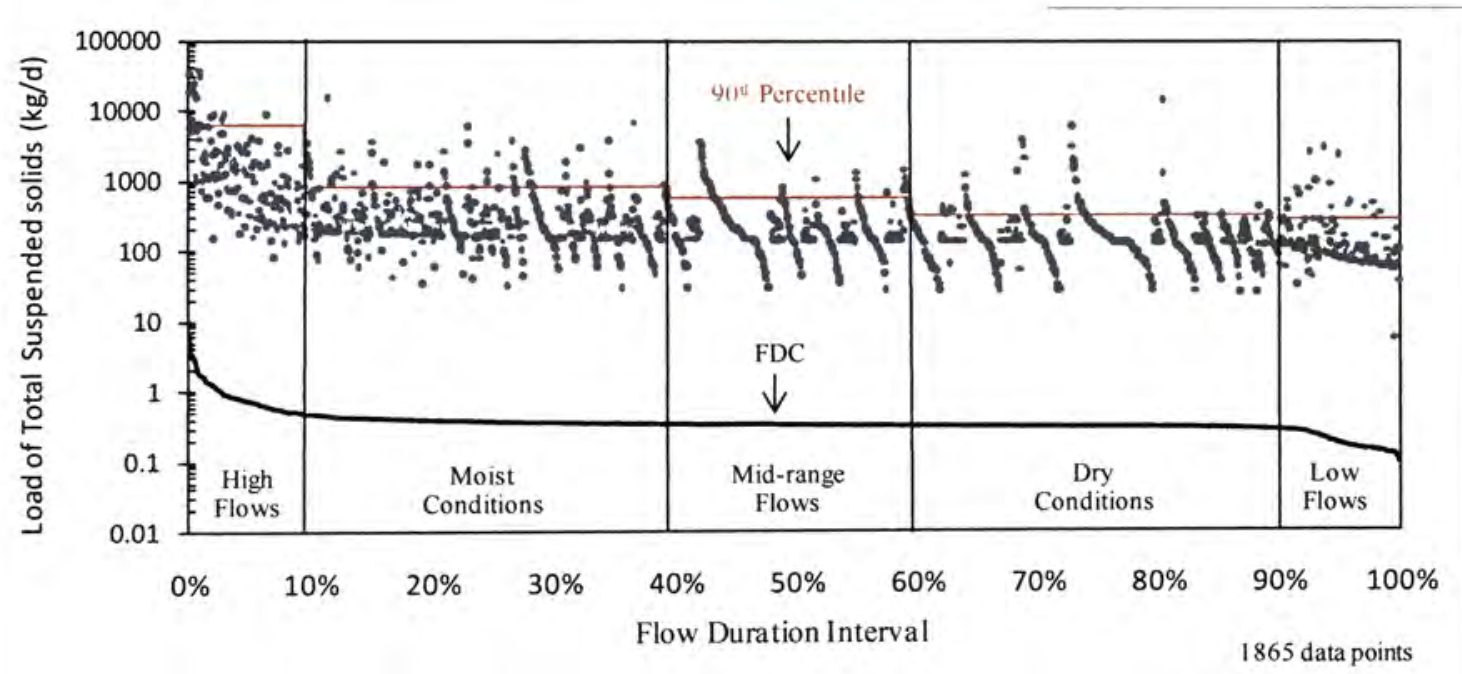

Figure 8 Load duration curve for suspended solids ranked by discharge at UEFPC Station 17 (data from OREIS database, years 1996-2009)

The load duration curve (LDC) was constructed by multiplying daily mean flow by the observed concentration of suspended solids in the water, as measured at Station 17. The results were ranked from highest to smallest flow and the probability per event was calculated from equation $(25) p_{i}=\frac{i}{n+1}$ 
Figure 8 shows the results. Table 7 presents the $90^{\text {th }}$ and $50^{\text {th }}$ percentile for TSS according to the level of flow, showing the relationship between discharge and levels of TSS, with higher concentrations of TSS occurring during high flows.

To show the relationship between suspended solids concentration and discharge, in Figure 9, suspended solids were ranked by flow: the $90^{\text {th }}$ and $50^{\text {th }}$ percentiles are presented in Table 7.

Table 7 TSS, Load of TSS, load of $\mathrm{Hg}, 90^{\text {th }}$ and $50^{\text {th }}$ percentile, under different flow conditions (data from OREIS database, years 1996-2008)

\begin{tabular}{|l|c|c|c|c|c|c|}
\hline \multicolumn{1}{|c}{ Flow } & $\begin{array}{c}\text { TSS 90th } \\
\text { percentile } \\
\mathbf{m g} / \mathrm{L}\end{array}$ & $\begin{array}{c}\text { TSS 50th } \\
\text { percentile } \\
\mathrm{mg} / \mathrm{L}\end{array}$ & $\begin{array}{c}\text { Load of } \\
\text { TSS 90th } \\
\text { percentile } \\
\mathrm{kg} / \mathrm{d}\end{array}$ & $\begin{array}{c}\text { Load of } \\
\text { TSS 50th } \\
\text { percentile } \\
\mathrm{kg} / \mathrm{d}\end{array}$ & $\begin{array}{c}\text { Load of } \\
\text { Hg 90th } \\
\text { percentile } \\
\mathrm{kg} / \mathrm{d}\end{array}$ & $\begin{array}{c}\text { Load of } \\
\text { Hg 50th } \\
\text { percentile } \\
\mathbf{k g} / \mathbf{d}\end{array}$ \\
\hline High Flows & 59.0 & 12.4 & 6401.0 & 958.0 & 0.240 & 0.050 \\
\hline $\begin{array}{l}\text { Moist } \\
\text { conditions }\end{array}$ & 24.5 & 6.4 & 827.0 & 218.0 & 0.035 & 0.013 \\
\hline $\begin{array}{l}\text { Mid-range } \\
\text { flow }\end{array}$ & 19.3 & 5.8 & 569.0 & 169.0 & 0.027 & 0.011 \\
\hline $\begin{array}{l}\text { Dry } \\
\text { conditions }\end{array}$ & 12.0 & 5.0 & 316.0 & 138.0 & 0.018 & 0.009 \\
\hline Low flow & 15.2 & 5.0 & 276.0 & 95.0 & 0.019 & 0.009 \\
\hline
\end{tabular}

The LDC for mercury was also constructed, by multiplying daily mean flow by the observed concentration of mercury in the water, as measured at Station 17. The results were ranked from highest to smallest flow (Figure 10). In this case, the observed concentration of total mercury is also higher during high flows, with a decrease of one order of magnitude (from $0.298 \mathrm{~kg} / \mathrm{d}$ to $0.024 \mathrm{~kg} / \mathrm{d}$ ) from high flow to low flow conditions. Table 7 presents the $90^{\text {th }}$ and $50^{\text {th }}$ percentiles for the load of mercury in $\mathrm{kg} / \mathrm{d}$, according to the level of flow. 


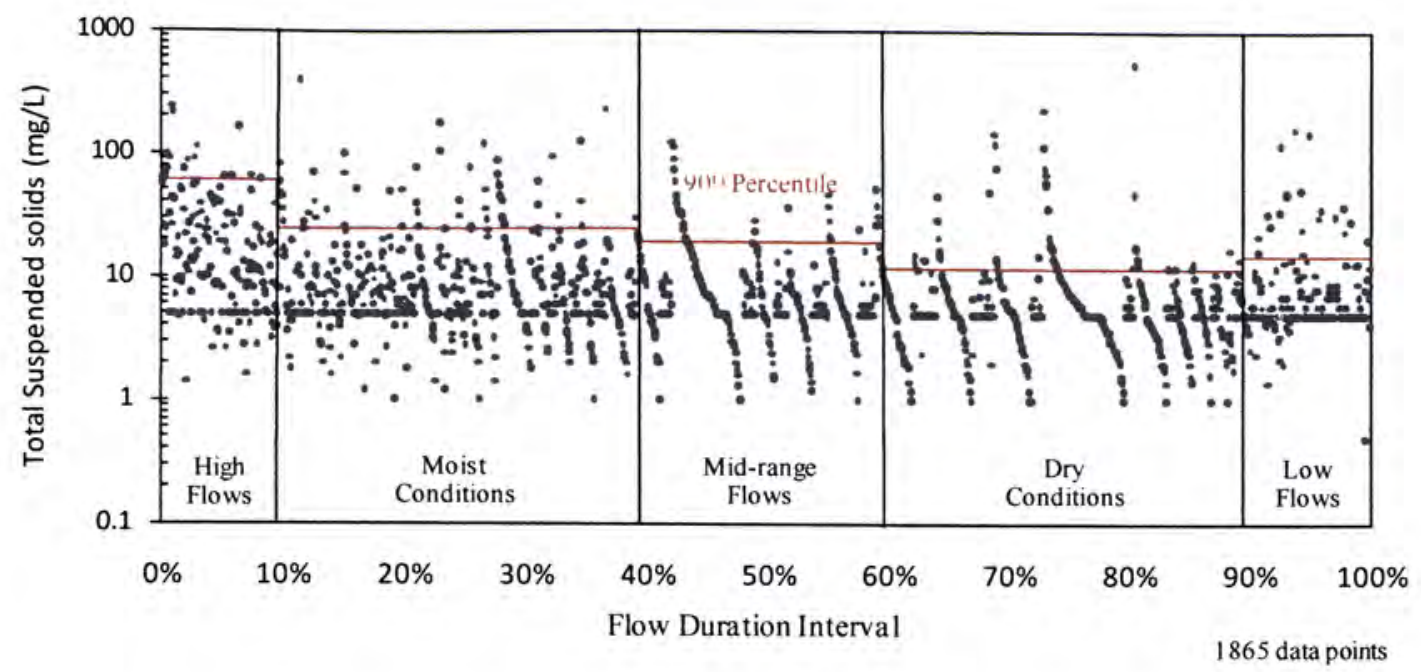

Figure 9 Total suspended solids by discharge at UEFPC Station 17 (data from OREIS database, years 1996-2009)

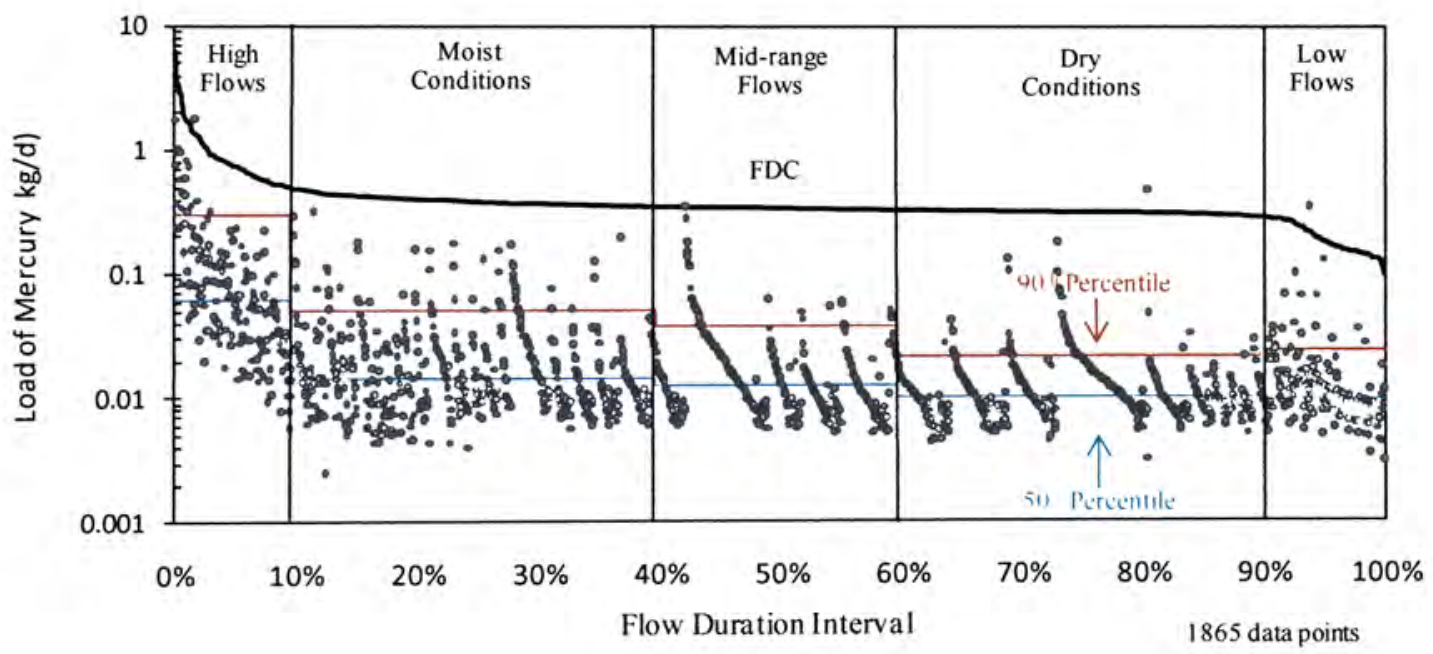

Figure 10 Load duration curve for mercury ranked by discharge at UEFPC Station 17 (data from OREIS database, years 1996-2008)

Calibration was carried out in two main steps. The first involved the parameters affecting the calculation of the total suspended solids in the system: the second step included the parameters affecting mercury concentrations and transport. 


\subsubsection{Sensitivity analysis for total suspended solids}

The simulation of suspended particles at the UEFPC presents a challenge due to the high variability in the levels of suspended particles as shown in Figure 11, with daily observed values that vary between 1 and $177 \mathrm{mg} / \mathrm{L}$, and have an average of $11 \mathrm{mg} / \mathrm{L}$ and a standard deviation of $21 \mathrm{mg} / \mathrm{L}$.

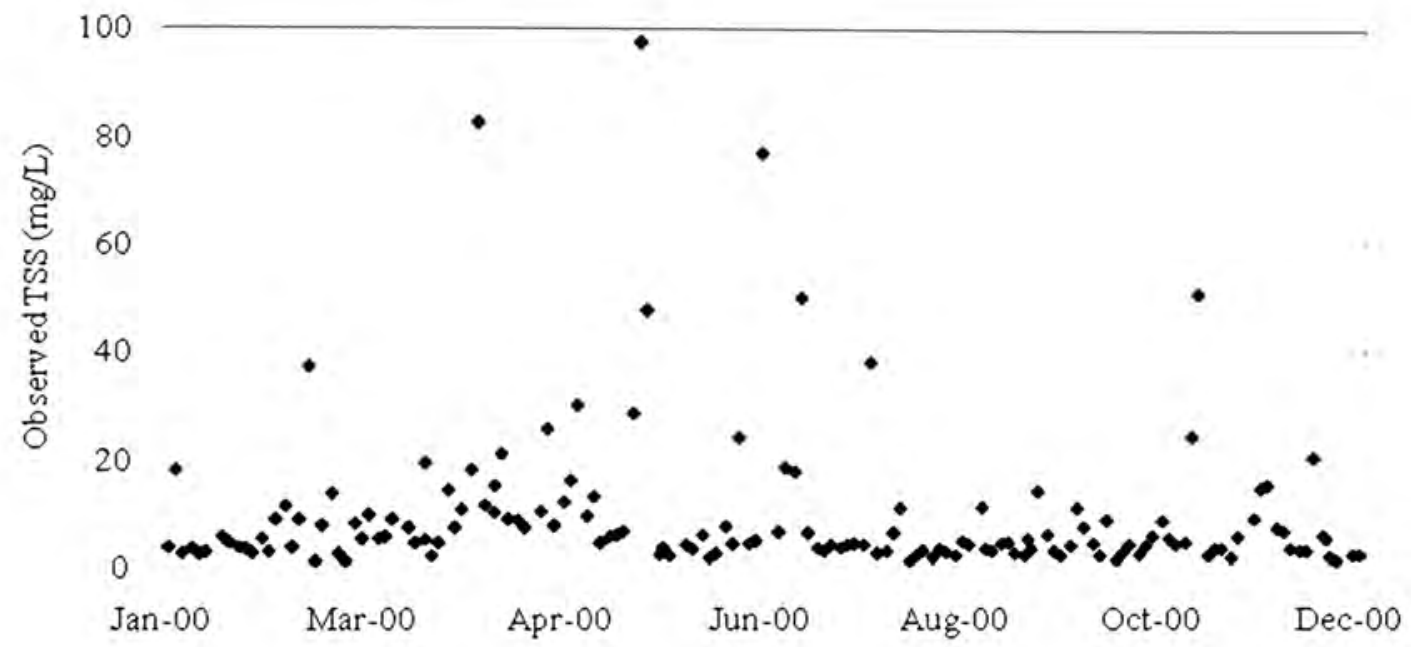

Figure 11 Total Suspended Solids at the UEFPC Station 17. Data from OREIS database year 2000

There are four input parameters in ECOLAB that directly affect the concentration of total suspended solids (TSS): critical current velocity $\left(\mathrm{v}_{\mathrm{c}}\right)$, settling velocity $\left(\mathrm{v}_{\mathrm{s}}\right)$, resuspension rate $(\mathrm{RR})$, and particle production rate (PPR). Simulations were run first for the year 2000 to find an acceptable range of parameters and then were extended for a period of 8 years (2000 to 2008) to finalize the calibration. The results are presented in the following sections, with an analysis based on load duration curves for both suspended solids and total mercury. Results are better described by load duration curves due to a high dependency of suspended solids and mercury concentration on the level of discharge in the creek. 


\subsubsection{Critical current velocity $\left(\mathrm{v}_{\mathrm{c}}\right)$}

Since the resuspension of particles from the bed occurs when the velocity of the stream is higher than the critical value for initiation of the movement $\left(\mathrm{v}_{\mathrm{c}}\right)$, lower values of this parameter contribute to the resuspension of more particles, increasing the load of suspended solids in the water column (Figure 12).

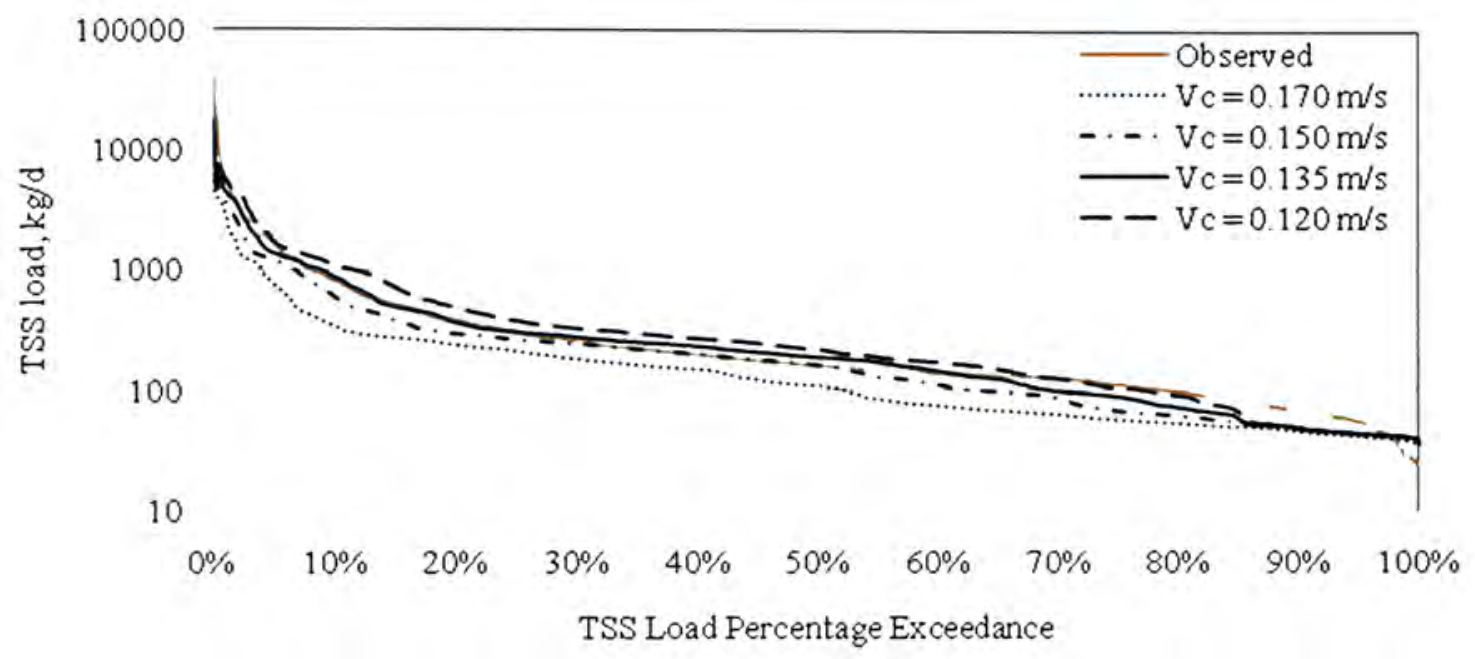

Figure 12 Effect of critical current velocity in the load of TSS

The effect of $\mathrm{v}_{\mathrm{c}}$ variations on TSS load is illustrated in Figure 13, where a $10 \%$ decrease in the critical current velocity (from 0.150 to $0.135 \mathrm{~m} / \mathrm{s}$ and from 0.135 to 0.120 $\mathrm{m} / \mathrm{s}$ ) highly affects the TSS load in the high loads range while almost no change is produced in the lower loads $(80 \%-100 \%$ percentage exceedance). In general, the decrease of $10 \%$ in $\mathrm{v}_{\mathrm{c}}$ increased the average TSS load by $26 \%$. TSS shows the highest sensitivity to critical current velocity among all other effective parameters in the ECOLAB module of the model. 


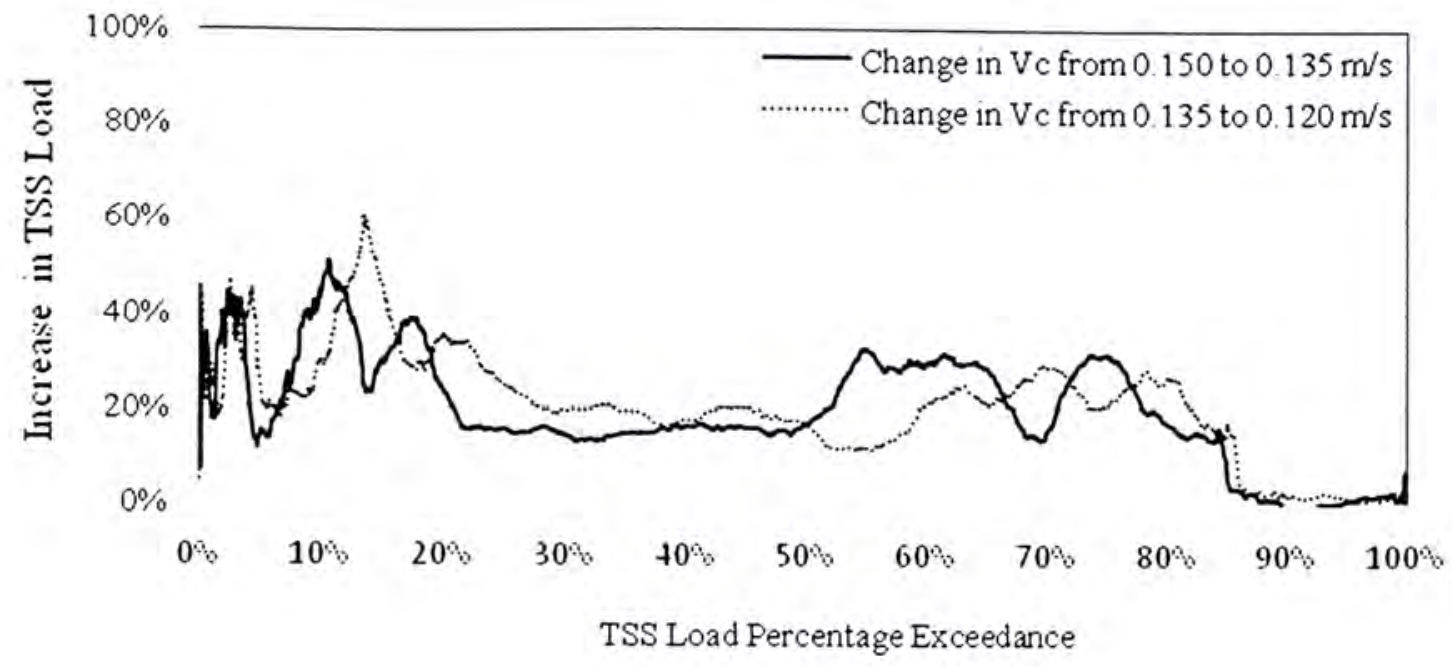

Figure 13 Effect in TSS load by decreasing critical velocity

After the sensitivity analysis, a value of $0.135 \mathrm{~m} / \mathrm{s}$ was chosen as the best value for this parameter, which makes the computed and observed data to be in the closest possible agreement (Figure 12).

\subsubsection{Resuspension Rate (RR)}

The resuspension rate is the most influential parameter on TSS peaks. The higher the resuspension rate, the higher the peak in the load of suspended solids, and in consequence, the higher the average concentration of TSS. Figure 14 shows the effect of $R R$ variations on the TSS load. An increase in RR leads to a higher increase in larger values of TSS load and a lower increase in lower values of TSS and could even result in a decrease in the very low values of TSS as shown in Figure 15. 


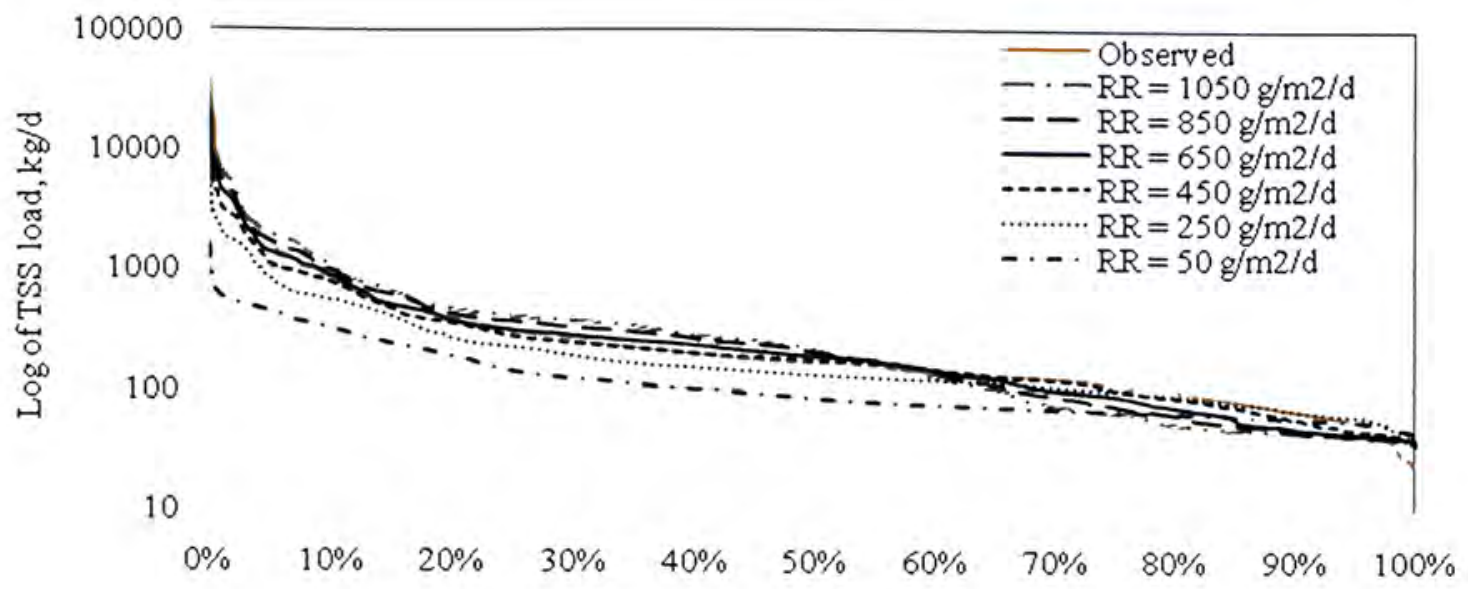

TSS Load Percentage Exceedance

Figure 14 Effect of resuspension rate in the load of TSS

After the sensitivity analysis on resuspension rate, the value of $650 \mathrm{~g} / \mathrm{m}^{2} / \mathrm{d}$ was chosen as it gives the least error when comparing computed load to the observed load (Figure 14).

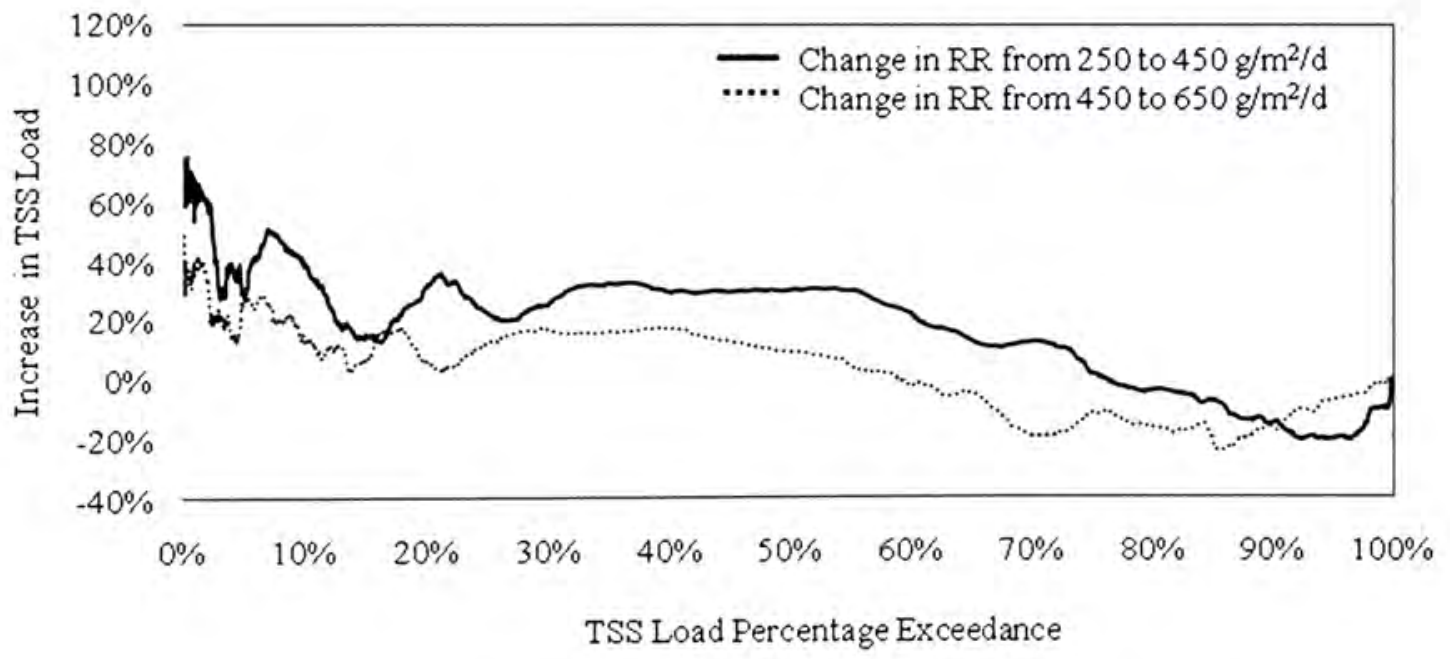

Figure 15 Effect in TSS load by increasing resuspension rate 


\subsubsection{Settling velocity $\left(V_{s}\right)$}

The lower the settling velocity, the longer it will take for particles to settle down, therefore increasing the TSS in water. In general, the TSS load increases with decreasing settling velocity as illustrated in Figure 16.

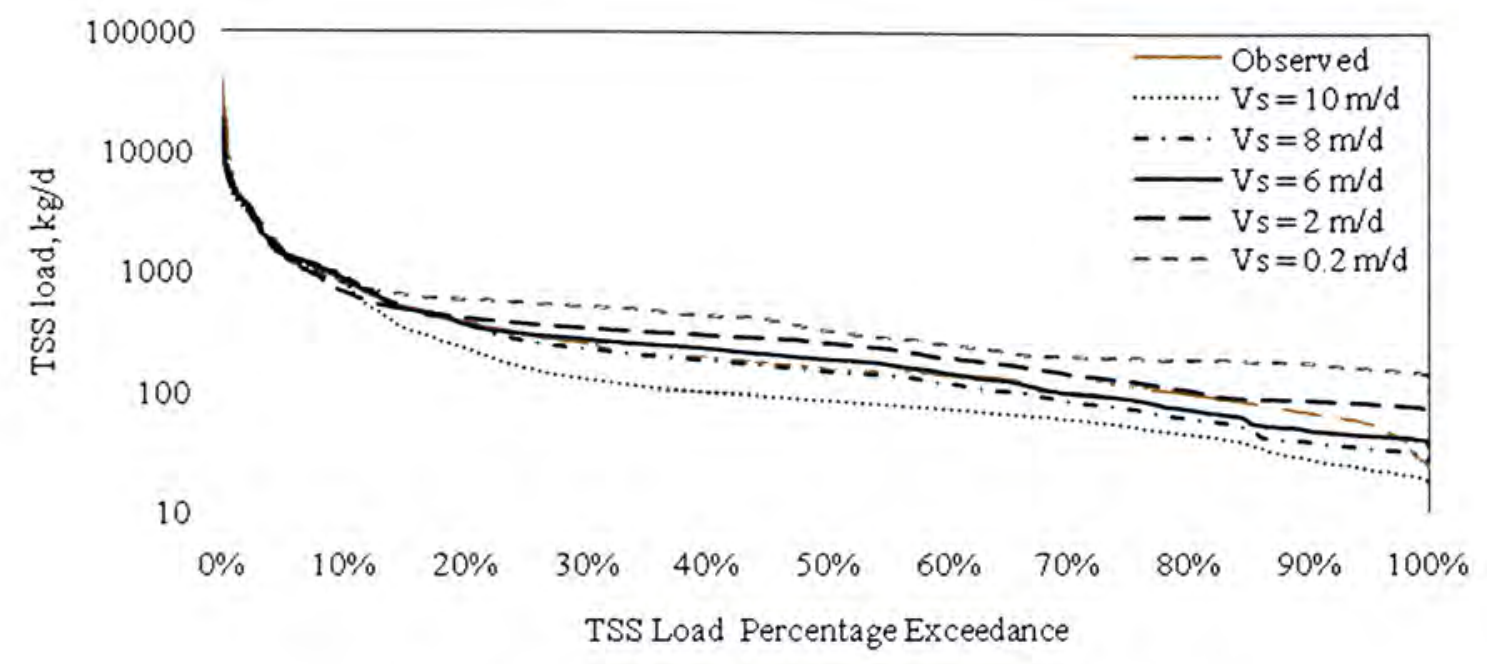

Figure 16 Effect of settling velocity in the load of TSS

Changes in settling velocity have the least effect on high loads, which correspond to the 0 to 20 percentage exceedance, and cause higher changes on lower TSS loads. In Figure 17 , a $25 \%$ decrease in the Vs increased the TSS load by about $20 \%$ in the midrange loads, while affecting lower loads only by $\pm 10 \%$. On average, during the 8-year period of the simulation, the load increased from 384 to $406 \mathrm{~kg} / \mathrm{d}$, about $6 \%$, as a result of a $25 \%$ decrease in the settling velocity.

Sensitivity analysis on settling velocity has been performed within the ranges for very fine and fine silt, calculated in Table 2, which is in agreement with the sizes of suspended particles present in the creek. A value of $6 \mathrm{~m} / \mathrm{d}$ was chosen as the best value which results in the best fit to the observed data. 


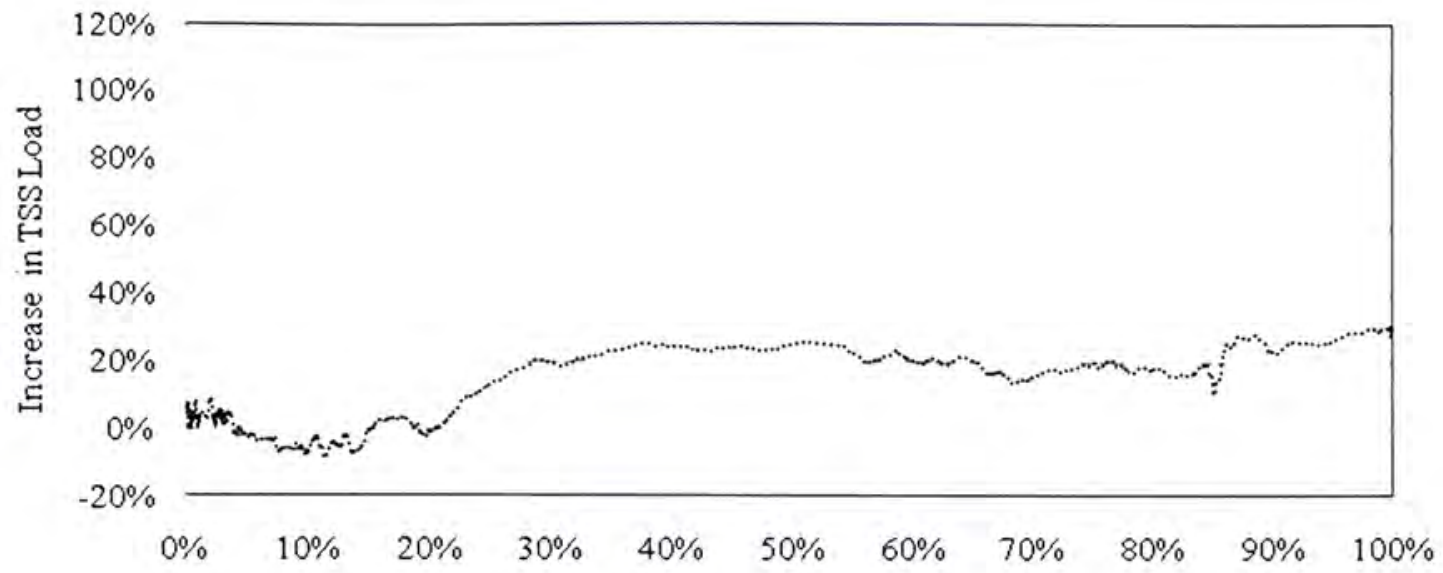

TSS Load Percentage Exceedance

Figure 17 Effect in TSS load by decreasing settling velocity from 8 to $6 \mathrm{~m} / \mathrm{d}$

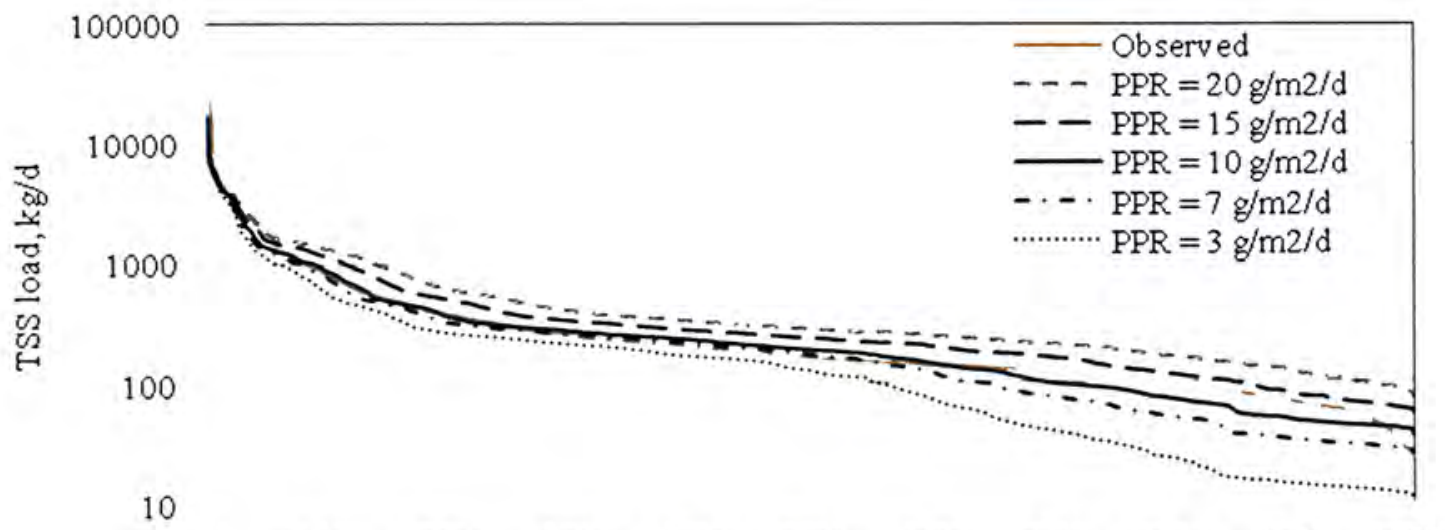

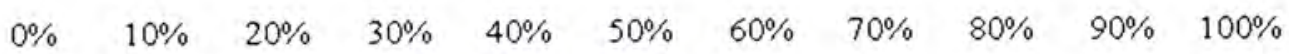

TSS Load Percentage Exceedance

Figure 18 Effect of particle production rate in the load of TSS

\subsubsection{Particle production rate (PPR)}

The particle production rate is a fixed coefficient that simulates waterborne particulate matter (DHI 2009). A series of simulations were run for different values of the parameter between 1 and $30 \mathrm{~g} / \mathrm{m}^{2} / \mathrm{d}$ while other parameters were set at default values. As 
shown in Figure 18, increasing the PPR increases the load of suspended solids in the water column, with higher effects on low loads (Figure 19).

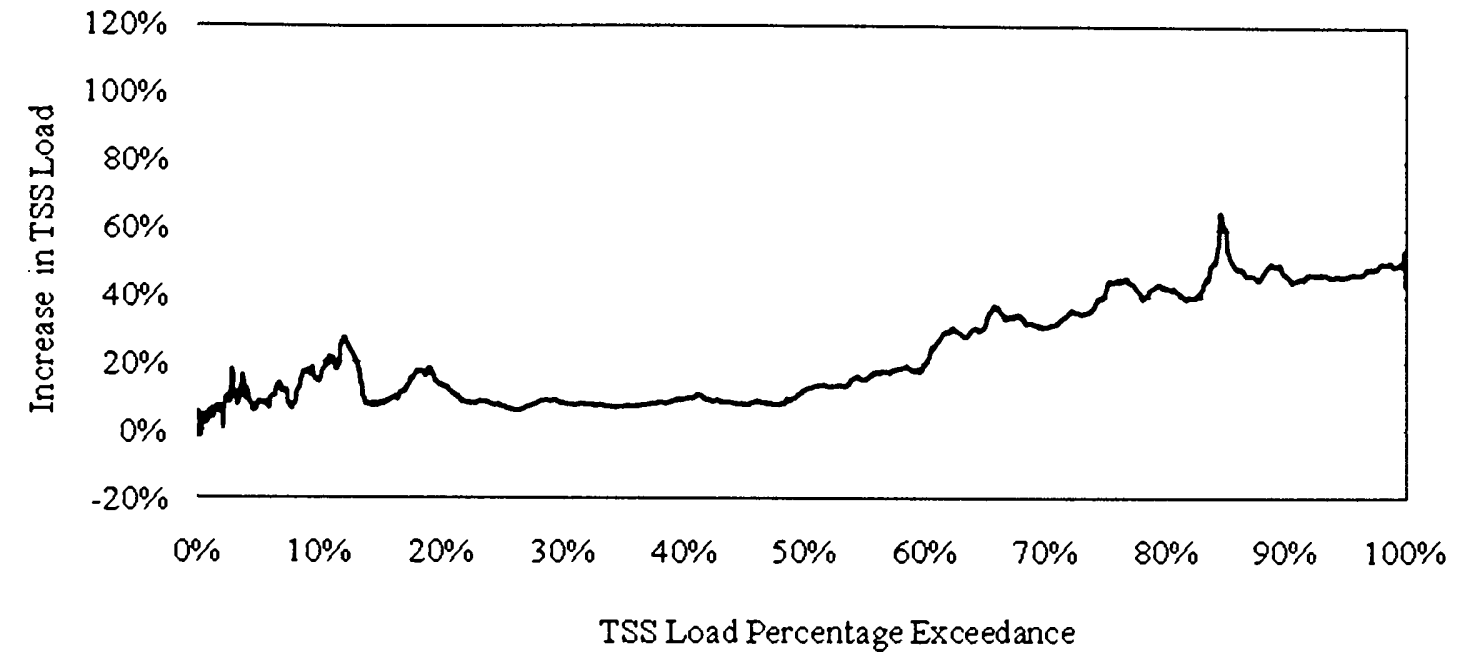

Figure 19 Effect in TSS load by increasing PPR from 7 to $10 \mathrm{~g} / \mathrm{m}^{2} / \mathrm{d}$

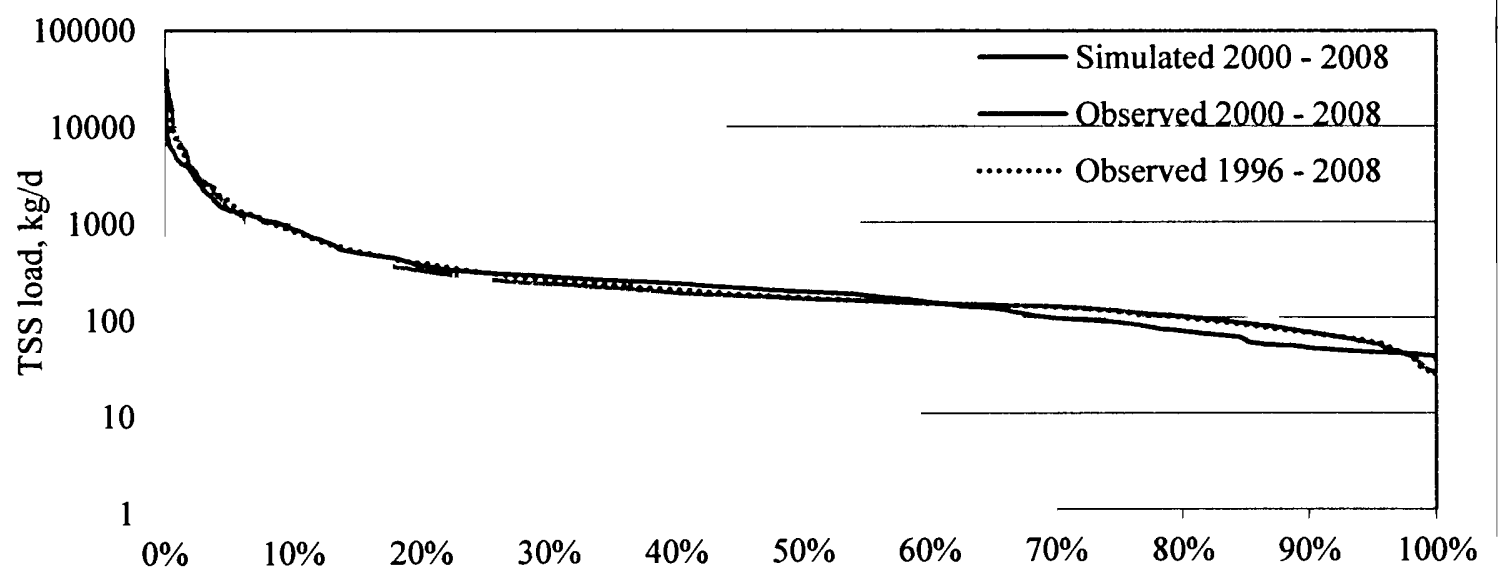
TSS Load Percentage Exceedance

Figure 20 TSS load simulated and observed (2000 - 2008), UEFPC-Station 17 Increasing the PPR by $43 \%$ (Figure 19) increased the average load of suspended solids during the 8-year simulation period by $10 \%$, from an average of $370 \mathrm{~kg} / \mathrm{d}(\mathrm{PPR}=7$ 
$\left.\mathrm{g} / \mathrm{m}^{2} / \mathrm{d}\right)$ to $406 \mathrm{~kg} / \mathrm{d}\left(\mathrm{PPR}=10 \mathrm{~g} / \mathrm{m}^{2} / \mathrm{d}\right)$. The average TSS increased from 10.17 to 11.36 $\mathrm{mg} / \mathrm{L}$ during the same period.

A value of $10 \mathrm{~g} / \mathrm{m}^{2} / \mathrm{d}$ was chosen as the best value for PPR following the sensitivity analysis as it creates the best agreement between the computed load and the observed load.

Figure 20 compares the computed and observed TSS load for a period of 8 years, including dry and wet years, with an average observed TSS of $11.72 \mathrm{~g} / \mathrm{m}^{3}$ and an average computed TSS of $11.36 \mathrm{~g} / \mathrm{m}^{3}$. Parameters for the simulation include particle production rate $\left(10 \mathrm{~g} / \mathrm{m}^{2} / \mathrm{d}\right)$, resuspension rate $\left(650 \mathrm{~g} / \mathrm{m}^{2} / \mathrm{d}\right)$, settling velocity $(6 \mathrm{~m} / \mathrm{d})$, and critical velocity $(0.135 \mathrm{~m} / \mathrm{s})$.

\subsubsection{Sensitivity analysis mercury variables}

In the present study, mercury concentration is being analyzed in four sub-domains: dissolved in the water, adsorbed in the water (particulate), dissolved in the sediment pore water, and adsorbed in the sediment. At the Station 17 of the UEFPC, total mercury in the water column (dissolved plus particulate) is measured in a regular basis but there is no consistent observed data that reports dissolved and adsorbed mercury separately. For the purpose of the calibration, the average percentage of the dissolved and adsorbed mercury in the water column was calculated from data collected during the biological monitoring and abatement program during 1997 and 1998 (Bechtel Jacobs 1999), presented in the appendix section under Table 14.

For mercury in sediment, there were a few observed values from the OREIS database from data collected in 1996 during the UEFPC remedial investigation. Data for dissolved mercury in pore water can be found in the Appendix section in Table 15 and has an 
average concentration of $0.00067 \mathrm{mg} / \mathrm{L}$ and a standard deviation of $0.00096 \mathrm{mg} / \mathrm{L}$. Data for adsorbed mercury in the sediment is presented in Table 16 and has an average concentration of $33.90 \mathrm{mg} / \mathrm{L}$ and a standard deviation $32.56 \mathrm{mg} / \mathrm{L}$.

There are four input parameters in ECOLAB that directly affect the concentration of mercury in the water column and/or the sediment: organic-carbon partition coefficient $\left(\mathrm{k}_{\mathrm{oc}}\right)$, fraction of organic carbon in suspended solids $\left(\mathrm{f}_{\mathrm{ocss}}\right)$, fraction of organic carbon in sediments $\left(f_{o c s e d}\right)$, desorption rate in water $\left(k_{w}\right)$ and desorption rate in sediments $\left(k_{s}\right)$. Since mercury in water is mainly (about $80 \%$ ) in the particulate form, the level of suspended solids in the water also plays an important role in the simulation of mercury concentration.

\subsubsection{Organic carbon partition coefficient and fraction of organic carbon}

The organic carbon partition coefficient $\left(\mathrm{k}_{\mathrm{oc}}\right)$ defines the concentration of mercury in the organic carbon component of the soil. As $\mathrm{k}_{\mathrm{oc}}$ refers to the organic carbon content of the soil, the parameter can be calculated from the relationship between the fraction of organic carbon $\left(f_{o c}\right)$ and the soil-water partition coefficient $\left(k_{d}\right)$ presented in equation (22). In the case of the EFPC, for the phase soil to water, a $k_{d}$ of $1796.7 \mathrm{~L} / \mathrm{kg}$ was reported for mercury, and an average $f_{o c}$ in soil of 0.003 (DOE 2005), which lead to a calculated $\mathrm{k}_{\mathrm{oc}}$ of $590,000 \mathrm{~L} / \mathrm{kg}$.

Following the sensitivity analysis, a value of $500,000 \mathrm{~L} / \mathrm{kg}$ was chosen as the best value for $\mathrm{k}_{\mathrm{oc}}$, as it creates the best agreement between the computed mercury concentrations and the observed values.

The major effect of $\mathrm{k}_{\mathrm{oc}}$ in the ECOLAB formulation is in the dissolved mercury in the sediment (Table 8). In general, as $\mathrm{k}_{\mathrm{oc}}$ decreases, the dissolved mercury in the sediment 
increases. If the fraction of organic carbon is kept constant, decreasing $\mathrm{k}_{\mathrm{oc}}$ results in a lower partition coefficient for the sediment $\left(\mathrm{k}_{\mathrm{dse}}\right)$, which represents an increasing affinity of the contaminant for the liquid phase, resulting in a higher concentration of dissolved mercury in the sediment.

No major effect was detected in the computed dissolved mercury in the water column, because the major parameter controlling it is mercury's desorption rate in water.

The fraction organic carbon coefficients were defined from average values for suspended solids and sediments in streams, presented by USEPA (2008) as 0.05 for suspended solids, and 0.02 for sediment (section 5.2.1).

Table 8 Effect of changes in $\mathrm{k}_{\mathrm{oc}}$ in mercury concentrations in water and sediment

\begin{tabular}{|r|c|c|c|c|}
\hline \multicolumn{1}{|c}{$\mathbf{k}_{\text {uc }}$} & $\begin{array}{c}\text { Diss. Hg } \\
\text { water } \\
\mathbf{m g} / \mathbf{L}\end{array}$ & $\begin{array}{c}\text { Ads. Hg } \\
\text { water } \\
\mathbf{m g} / \mathbf{L}\end{array}$ & $\begin{array}{c}\text { Diss. Hg } \\
\text { sediment } \\
\text { mg/L }\end{array}$ & $\begin{array}{c}\text { Ads. Hg } \\
\text { sediment } \\
\text { mg/kg }\end{array}$ \\
\hline $1,000,000$ & 0.000217 & 0.000447 & 0.000237 & 29.55 \\
\hline 700,000 & 0.000221 & 0.000445 & 0.000337 & 29.54 \\
\hline 500,000 & 0.000224 & 0.000444 & 0.000472 & 29.53 \\
\hline 50,000 & 0.000232 & 0.000434 & 0.004700 & 29.16 \\
\hline 5,000 & 0.000232 & 0.000434 & 0.046370 & 29.16 \\
\hline
\end{tabular}

The above parameters resulted in a $\mathrm{k}_{\mathrm{d}}$ of $25,000 \mathrm{~L} / \mathrm{kg}$ for the phase suspended solids/water column, and $\mathrm{k}_{\mathrm{d}}$ of $10,000 \mathrm{~L} / \mathrm{kg}$ for the phase sediment/pore water.

\subsubsection{Desorption rate in water}

The desorption rate of mercury in water $\left(\mathrm{k}_{\mathrm{w}}\right)$ is one of the most important parameters in the simulation of dissolved and adsorbed mercury in the water, along with the level of suspended solids in the system. Simulations were carried out varying the parameter between $0.0003 / \mathrm{d}$ and $30 / \mathrm{d}$. As $\mathrm{k}_{\mathrm{w}}$ decreases the dissolved mercury in the water column 
decreases and the adsorbed mercury increases, generating also a decrease in the total mercury.

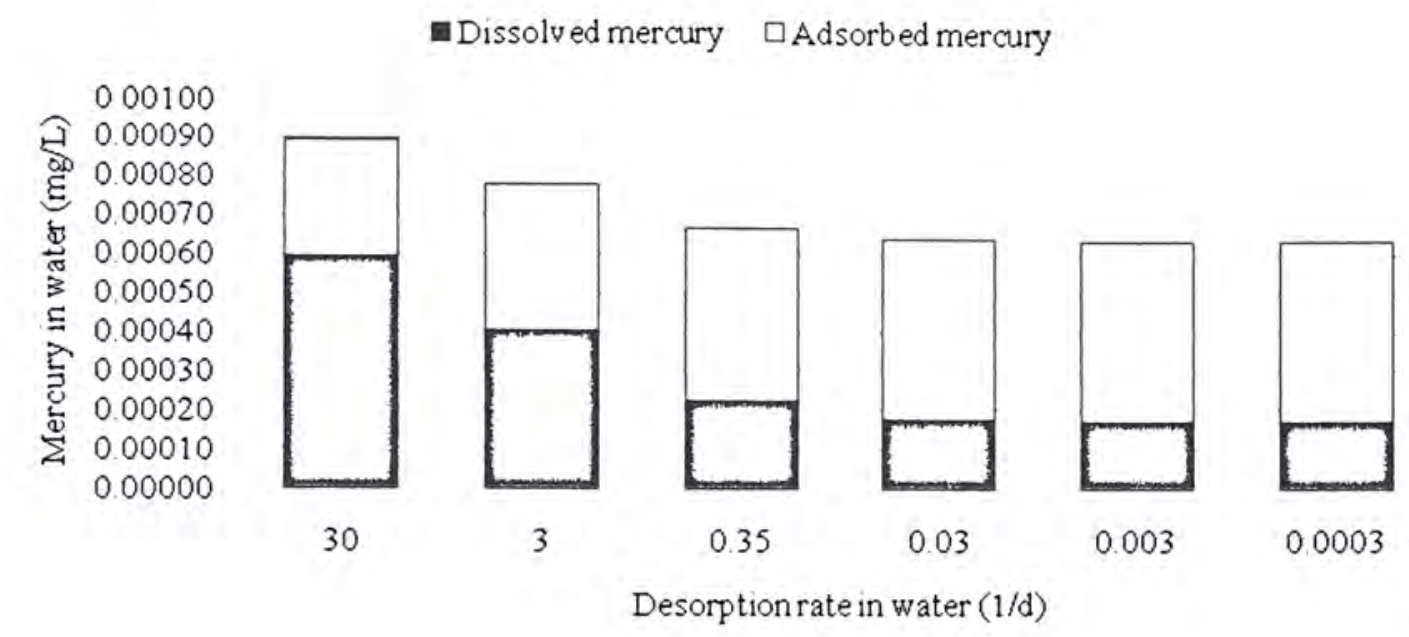

Figure 21 Effects in mercury concentration in water by changing $k_{w}$

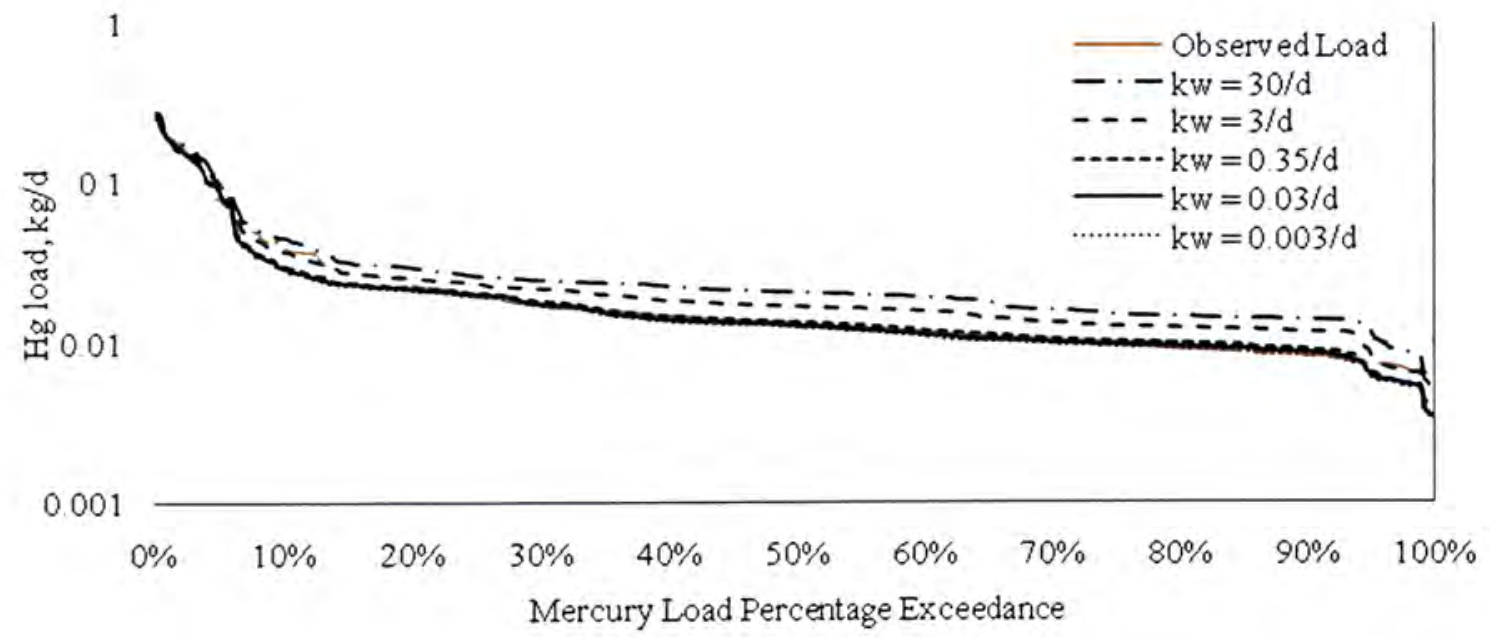

Figure 22 Effect in load of mercury as desorption rate in water changes

A decrease in $\mathrm{k}_{\mathrm{w}}$ generates a decrease in the load of total mercury in the water column as shown in Figure 22, with no noticeable effect in rates below $0.003 /$ d. After the sensitivity analysis, a value of $0.03 / \mathrm{d}$ was chosen as the best value for the parameter, as it 
makes the computed mercury (dissolved and adsorbed) concentrations and the load of total mercury to be in the best agreement with the observed values.

\subsubsection{Suspended solids concentration}

The level of suspended solids in the system is a determinant factor in the total mercury in the water. The observed adsorbed mercury represents about $85 \%$ of the total mercury in the water column (Table 14), which explains the sensitivity of the model to the concentration of suspended solids.

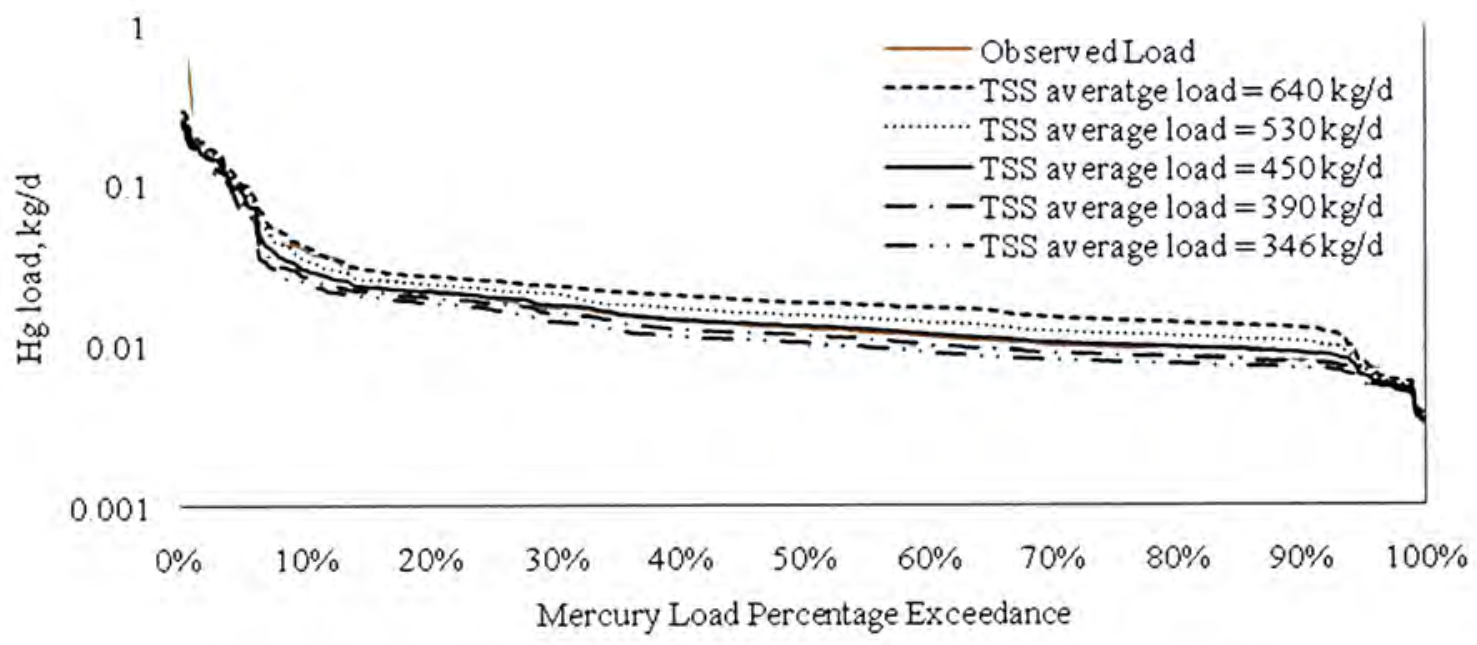

Figure 23 Effect in load of mercury as TSS load changes

\section{DISCUSSION}

Numerical model results show that most of the mercury in the water column is in the form of particulate mercury; the high affinity of mercury to the organic component of the soil (high $\mathrm{k}_{\mathrm{d}}$ ) contributes to such behavior. 


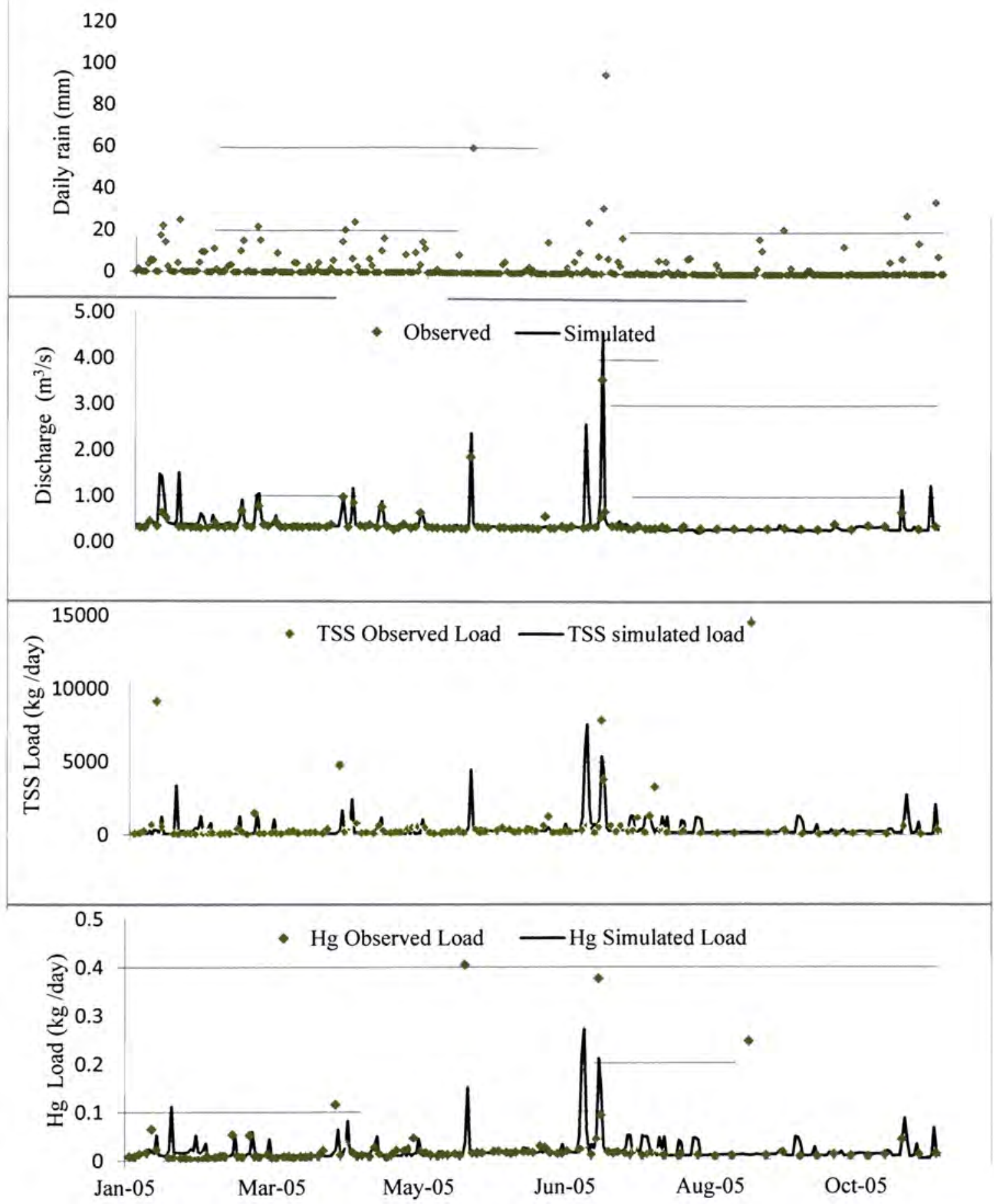

Figure 24 Observed and Simulated rainfall, Q, TSS load and Hg load, UEFPCStation 17, year 2005. Observed values from OREIS database. 
During rain events, the water flow is higher, which causes the shear stress (friction of the water against the bed of the channel) to overcome the critical value for initiation of movement, moving mercury contaminated particles into the water column. Figure 24 presents results from the calibrated model, along with observed values, for the year 2005 . During the month of July, the highest rain events of the year occurred: $31 \mathrm{~mm} /$ day on the $13^{\text {th }}$, and $95 \mathrm{~mm} /$ day on the $14^{\text {th }}$, as measured at Station 17 (OREIS Database). Results from the model during the days following the high rain events show an increase in the water flow, up to $4.6 \mathrm{~m}^{3} / \mathrm{s}$, a significant increase from a yearly average of $0.4 \mathrm{~m}^{3} / \mathrm{s}$. The load of suspended solids increased up to 7,569 kg/d (simulated) and 7,848 kg/d (observed) from an average of $373 \mathrm{~kg} / \mathrm{d}$. The load of mercury in the water increased up to $0.27 \mathrm{~kg} / \mathrm{d}$ (simulated), and $0.37 \mathrm{~kg} / \mathrm{d}$ (observed), from a yearly average of $0.019 \mathrm{~kg} / \mathrm{d}$. This shows the correlation between the increased total mercury and the increased mercury-contaminated suspended solid loads.

About 43 outfalls discharge into the UEFPC and constitute a point source for mercury into the creek, bringing residual mercury from the Y12 plant as a result of the collection of stormwater. Observed discharge and total mercury contribution from those outfalls are included in the model as a boundary condition. Results from the model show that during the year 2005, a total mass of $6.8 \mathrm{~kg}$ of mercury passed through Station 17, from which $4.6 \mathrm{~kg}(68 \%)$ were contributed by the outfalls. It can be inferred that the remaining $32 \%$ originated from non-point sources, presumably the exchange of particulate mercury with the river bed. The proportion between total mercury load and point source contribution, for the year 2005, can be observed in Figure 25. Furthermore, the accumulated load is presented in Figure 26. 
10000

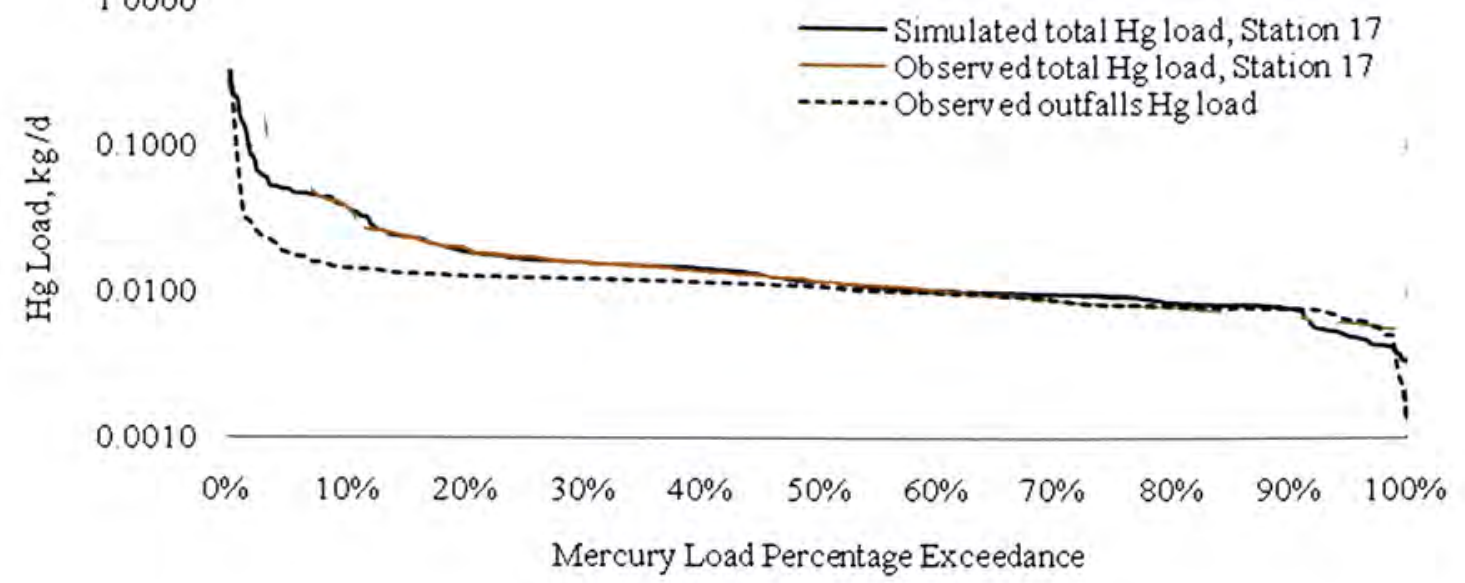

Figure 25 Mercury load from outfalls and total at Station 17

Even though there was an increase in the total mercury load from outfalls during the high rain events, the maximum load generated from the outfalls in a single day $(0.32 \mathrm{~kg} / \mathrm{d}$ in July 2005) is not enough to explain the maximum load in a single day $(0.38 \mathrm{~kg} / \mathrm{d})$ measured at Station 17 , about $20 \%$ higher for this day.

Load from outfalls Load at Station 17

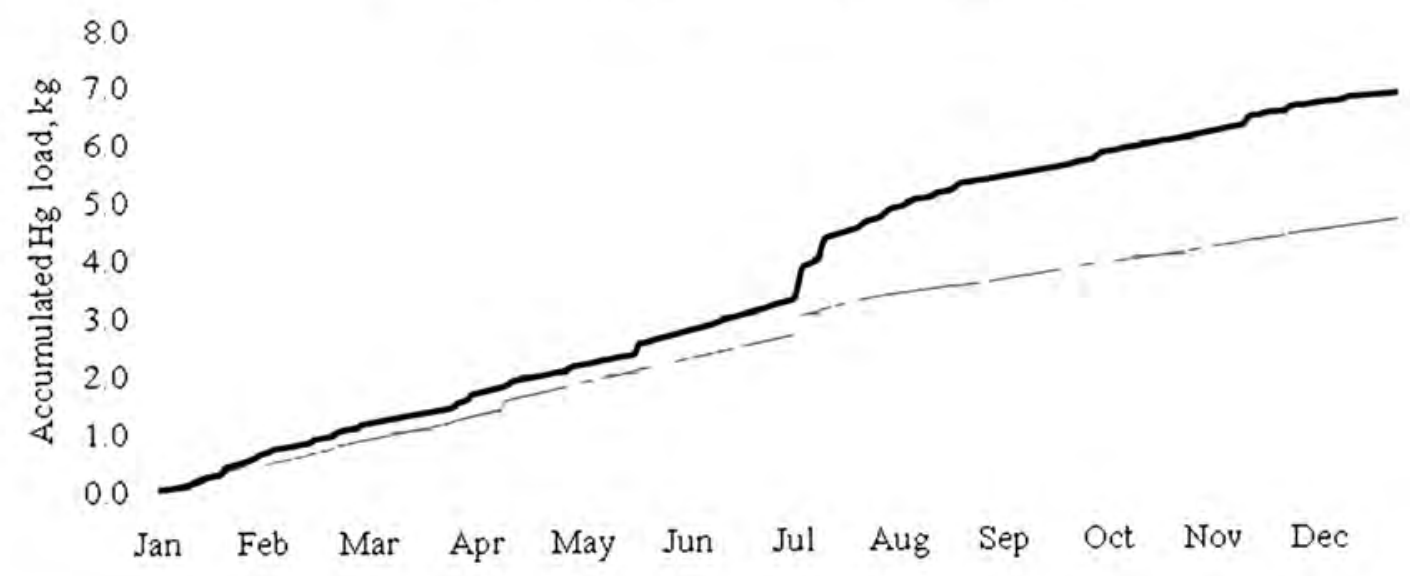

Figure 26 Accumulated mercury load from outfalls and total at Station 17 
As a result of the implementation of the sedimentation module (ECOLAB), the prediction capability of the model has been improved, as can be observed in Figure 27, where the simulated load of mercury with ECOLAB shows a better fit with the observed data. The simulation period covers years 2000 to 2008 .

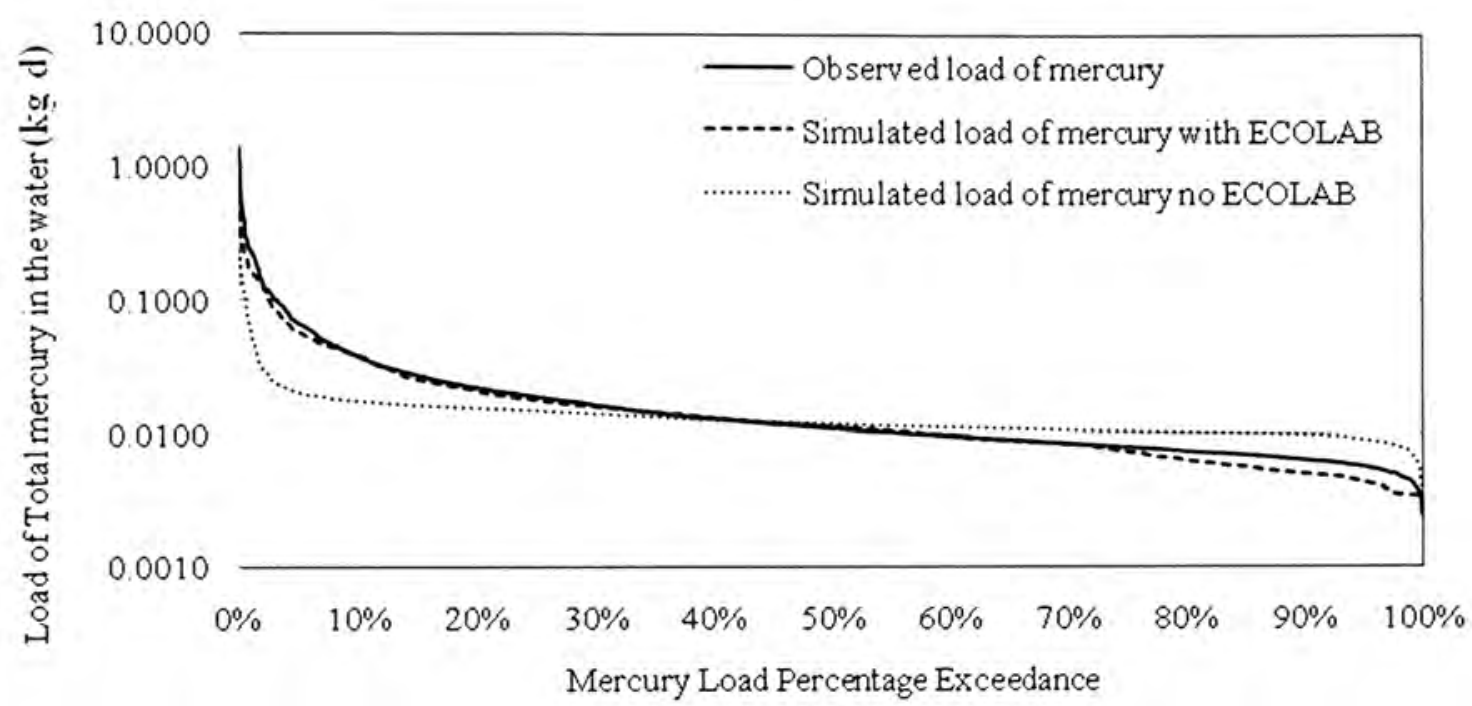

Figure 27 Simulated load with and without ECOLAB

\section{CONCLUSIONS}

The ECOLAB water quality model was used to add the exchange of mercury between sediments and stream flow to the existing flow and transport model built in MIKE SHE/MIKE11 software, for the Upper East Fork Poplar Creek Watershed, located in Oak Ridge, Tennessee. The contribution of small mercury contaminated particles settling down into the riverbed and being resuspended by changes in hydrodynamic conditions in the creek is fundamental to the accurate simulation of mercury concentrations in streams. The higher surface area characteristic of clay and silt particles increases their capacity to adsorb higher concentrations of mercury when compared with coarser particles, 
explaining the importance of studying the interaction between suspended sediments and the contaminant.

The transport processes in the ECOLAB module are defined by the constant interaction among four river sub-domains: dissolved mercury in the water, adsorbed mercury in the suspended solids in the water, dissolved mercury in the sediment pore water, and adsorbed mercury in the sediment. Adsorption/desorption of the metal occurs to and from particulate and dissolved phases in the water column and in the sediment bed. Diffusive transfer of dissolved metal occurs between the water column and the sediment pore water.

Results from the sensitivity analysis show that among all the parameters in the ECOLAB module, suspended solids have the highest sensitivity to critical current velocity; the resuspension rate is the most influential parameter for the simulation of TSS peaks while particle production rate and settling velocity have more influence for lower loads. In general, the TSS load increases when the resuspension rate and/or particle production rate increases, and when the settling velocity and/or the critical velocity decreases.

Among the ECOLAB variables controlling mercury concentration in the sediments, and water column, the organic carbon partition coefficient $\left(\mathrm{k}_{\mathrm{oc}}\right)$ has the largest effect on the dissolved mercury in the sediment. In general, as $\mathrm{k}_{\mathrm{oc}}$ decreases, the dissolved mercury in the sediment increases, as it represents an increasing affinity of the contaminant for the liquid phase. The desorption rate of mercury in water $\left(\mathrm{k}_{\mathrm{w}}\right)$ is the variable controlling the dissolved and adsorbed mercury in the water column; increase in this rate results in 
higher dissolved mercury and lower particulate mercury. The concentration of suspended solids in the water is also a major parameter in the simulation of adsorbed mercury in the water column.

Total mercury concentrations in the water column are strongly influenced by the hydrodynamics of the water body. The numerical model results show a high correlation between water flow, suspended solids load, and mercury concentration in the water, highlighting the importance of the exchange of small particles with the bed, which serves as a continuous source of mercury to the surface water. After considering the mass of mercury contributed by the outfalls it was concluded that, in $2005,32 \%$ of the mercury measured at Station 17 originated from non-point sources, most likely the exchange of sediments with the bed.

Mercury in water is found in both the dissolved and the particulate phase. In the dissolved phase, mercury bounds to the dissolve organic carbon, and in the particulate phase it bounds to suspended solids. According to the simulation results, approximately $73 \%$ of the total mercury in the water column is particulate bound. This behavior can be attributed to the high affinity of mercury to the organic matter content of the sediments; in consequence, the higher the fraction of organic carbon, the higher the affinity of the metal for the particulate phase. 


\section{REFERENCES}

Abbott, M. B., and J. C. Refsgaard. "Distributed Hydrological Modeling." Kluwer Academic: Dordrecht, 1996.

Allison, Jerry, and Terry Allison. "Partition Coefficients for Metals in Surface Water, Soil and Waste ." Office of Research and Development, US Environmental Protection Agency, Washington, DC, 2005.

Andrews, E.D. "Entrainment of gravel from naturally sorted riverbed material." Geological Society of America Bulletin 94 (October 1983): 1225-1231.

Ashwood, T.L., C.R. Olsen, I.L. Larsen, and P.D. Lowry. Sediment Contamination in Streams Surrounding the Oak Ridge Gaseous Diffusion Plant. Oak Ridge: Oak Ridge National Laboratory, 1986.

Bao, Yixing. "Predicting sediment and Cesium-137 transported to offsite during extreme floods." Oak Ridge National Laboratory. Environmental Science Division Publication 4853, 1999.

Bechtel Jacobs. "Determination of Site-Specific Aqueous Concentration Goals for Controlling Mercury Bioaccumulation in Fish in East Fork Poplar Creek: Result of Studies Undertaken by the Y-12 Biological Monitoring and Abatement Program (BMAP) at the Oak Ridge Y-12 Plant." Oak Ridge, TN, 1999.

Beheshti, A.A., and B. Ataie-Ashtiani. "Analysis of threshold and incipient conditions for sediment movement." Coastal Engineering, 2008: 423-430.

Brigham, Mark, Dennis Wentz, George Aiken, and David Krabbenhoft. "Mercury Cicling in Stream Ecosystems. 1. Water Column Chemistry and Transport." Environmental Science Technology 43 (2009): 2720-2725.

Brooks, S.C., and G.R. Southworth. "History of Mercury use and Environmental Contamination at the Oak Ridge Y-12 Plant." Environmental Pollution, 2011: 219-228.

Chapra, Steven. Surface Water-Quality Modeling . Long Grove, IL: Waveland Press, Inc, 1997.

Cheng, Nian-Sheng. "Simplified Settling Velocity Formula for Sediment Particle ." Journal of Hydraulic Engineering, 1997: 149-152.

Choi, Sung-Uk, and Seungjo Kwak. "Theoretical and Probabilistic Analysis of incipient motion of sediment particles." KSCE Journal of Civil Engineering 5, no. 1 (March 2001): 59-65. 
DENR, NC. "North Carolina Department of Environment and Natural Resources. Total Maximum Daily Load for Mercury in the Cashie River, North Carolina. Public Review Draft 7/28/2004." NC DENR. 2004. North Carolina Department of Environment and Natural Resources. Total Maximum Daily Load for Mercury in the Cashie River, North Carolina. Public Review Draft 7/28/2004, North Carolina, 2004.

DHI. Heavy Metal Template ECOLAB Scientific Description. Hørsholm, Denmark: Danish Hydraulic Institute, 2009.

DHI. MIKE 11 A modelling system for rivers and channels, user guide. Hørsholm, Denmark: Danish Hydraulic Institute, 2009b.

DHI. MIKE 11 Short Descriptions . Hørsholm, Denmark: Danish Hydraulic Institute, 2008.

DOE. "East Fork Poplar Creek - Sewer Line Beltway Remedial Investigation Report, Volume I, Science applications International Corporation, 1994." 1994.

DOE. Instream Contaminant Study Task 5, Summary Report. Oak ridge, Tennessee: Office of Natural Resources and Economic Development Tennessee Valley of Authority, 1986b, 223, .

DOE. "Instream Contaminat Study Task 2, V2. Sediment Characterization." Office of Natural Resources and Economic Development Tennessee Valey of Authority, 1986.

DOE. "Proposed Plan for Interim Source Control Actions for Contaminated Soils, Sediments, and Groundwater (Outfall 51) which Contribute to Mercury and PCB Contamination to Surface Water in the Upper East Fork Poplar Creek Characterization Area." Oak Ridge, Tennessee: Department of Energy, 2001.

DOE. Recommendations to Address Technical Uncertainties in Mitigation and Remediation of Mercury at the Y-12 Plant, Oak Ridge. Office of Environmental Management, Department of Energy, Oak Ridge, Tennessee: Department of Energy, 2008 .

DOE. Record of Decision for Phase II Interim Remedial Actions for Contaminated Soils and Scrapyard in Upper East Fork Poplar Creek. Oak Ridge, Tennessee: U.S. Department of Energy Office of Environmental Management, 2005.

DOE. Record of Decision for Soil, Buried Waste, and Subsurface Structure Actions in Zone 2, East Tennessee Technology ParK. Oak Ridge, Tennessee: U.S. Department of Energy Office of Environmental Management, 2005b.

DOE. "Report on the Remedial Investigation of the Upper East Fork Poplar Creek Characterization Area at the Oak Ridge Y-12 Plant, Oak Ridge, Tennessee, Volume 1, DOE/OR/01-1641/V1\&D2." 1998. 
DOE. "Report on the Remedial Investigation of the Upper East Frok Poplar Creek Characterization Area at the Oak Ridge Y-12 Plant. Volume 1." Oak Ridge, Tennessee, 1998.

Ebinghaus, R., R.R. Turner, L.D. de Lacerda, O Vasiliev, and W Salomons. Mercury Contamnated Sites. New York: Springer, 1999.

Emmet et al., Owens. "Resuspension of Mercury-Contaminated Sediments from an In-Lake Industrial Waste Deposit." Journal of Environmental Engineering, July 2009: 526-534.

Gandhi et al., Nilima. "Development of a Mercury Speciation, Fate and Biotic Uptake (BIOTRANSPEC) Model; Application to Lahontan Reservoir (NEVADA, USA)." Environmental Toxicology and Chemistry 26, no. 11 (2007): 2260-2273.

Garde, R.J., and K.J. Tanga Raju. Mechanics of Sediment Transportation and Alluvial Stream Problems. Second Edition. John Wiley \& Sons, 1985.

Gray, J. R., G.D Glysson, L.M Turcios, and G.E. Schwartz. Comparability of Suspended-Sediment Concentration and Total Suspended Solids Data, Water Resources Investigations Report 00-4191. Reston, Virginia.: U.S. Geological Survey, 2000.

Guo, Qizhong. "Correlation of Total Suspended Solids (TSS) and Suspended Sediment Concentration (SSC) Test Methods." Department of Civil and Environmental Engineering, The State University of New Jersey, Trenton, NJ, 2006.

Hallermeier, Robert. "Terminal Settling Velocity of Commonly Occurring Sand Grains." Sedimentology, 1981: 859-865.

Han, Fengxiang, et al. "extractability and Bioavailability of Mercury from a Mercury Sulfide Contaminated Soil in Oak Ridge. Tennessee, USA." Water Air Soil Pollution, 2008: 67-75.

Hill, Walter, Michael Ryon, John Smith, Marshall Adams, Harry Boston, and Arthur Stewart. "The Role of Periphyton in Mediating the Effects of Pollution in a Stream Ecosystem." Environmental Management, 2010: 563-576.

Honeyman, Bruce D, and H Peter Santschi. "Metals in Aquatic Systems." Environmental Science and Technology 22, no. 8 (1988): 862-871.

Kaleri, Cinthia. "Implementation Issues: Mercury Transport and Fate. combustion Risk Assessments in Region 6." EPA - Proceding of the 12th International conference. Dallas - Texas, 2000.

Kuwabara, James, and others. Flux of Dissolved Forms of Mercury Across the Sediment-water Interface in Lahontan Reservoir, Nevada. U.S. Geological Survey, Nevada: U.S. Geological Survey, 2002. 
LaGrega, Michael D, Philip L Buckingham, and Jeffrey C Evans. Hazardous Waste Management. Second. McGraw-Hill, 2001.

Levine, Daniel, William Hargrove, and Hoffman Forrest. "Characterization of Sediments in the Clinch River, Tennessee, Using Remote Sensing and Multidimensional GIS Techniques." Vancouver, British Columbia, 1995. 548-551.

Liao, Lixia, H.M. Selim, and R.D. DeLaune. "Mercury Adsorption-Desorption and Transport in Soils." Journal of Environmental Quality 38, no. July-August (2009): 16081616.

Lyon, B.F. "Calculation of Soill-Water and Bentic Partition Coefficients for Mercury." Chemosphere, 1997: 791-808.

Miller, Carrie L., George Southworth, Scott Brooks, and Baohua Gu. "Kinetic Controls in the Complexation between Mercury and Dissolved Organic Matter in a Contaminated Environment." Environmental Science Technology 43 (2009): 8548-8553.

Moran, Barry. "Modeling of the Hydrologic Transport of mercury in the Upper East Fork Poplar Creek." Knoxville (Ternnessee), December 1996.

Morel, F. M., A.M. Kraepiel, and M Amyot. "The Chemical Cycle and Bioaccumulation of Mercury." Annual Review of Ecology and Systematics 29 (1998): 543-566.

Nriagu, Ed. The Biochemistry of Mercury in the Environment. Amsterdan, The Netherlands, North Holland: Biomedical Press, 1979.

Pant, P, and M Allen. "Interaction of Soil and Mercury as a Function of Soil Organic Carbon." Bull Environmental Contaminant Toxicology, 2007.

Parkpoin, Preeda, Waewtaa Thongra-ar, Ronald DeLaune, and Aroon Jugsujinda. "Adsorption and Desorption of Mercury by Bangpakong River Sediments as Influenced by Salinities." Journal of Environmental Science and Health, 2001: 623-640.

Pelcova, Pavlina, Jana Margetinova, Tomas Vaculovic, Josef Komarek, and Vlastimil Kuban. "Adsorption of Mercury Species on River Sediments - Effects of Selected Abiotic Parameters." Central European Journal of Chemistry, 2010: 116-125.

Reimers, Robert, and Peter Krenkel. "Kinetics of Mercury Adsorption and Desorption in Sediments." Water Pollution Control Federation 46, no. 2 (1974): 352-365.

Rothschild, E.R., et al. Investigation of Subsurface Mercury at the Oak Ridge Y-12 Plant, ORNL/TM-9092. Oak Ridge, TN: Oak Ridge National Laboratory, 1984.

Schnoor, Jerald L. Environmental Modeling. Fate and Transport of Pollutants in Water, Air, and Soil. New York: John Wiley \& sons, Inc., 1996. 
Southworth, G.R., et al. Controlling Mercury Release from Source Zones to Surface Water: Initial Results of Pilot Tests at the Y-12 National Security Complex. Oak Ridge, TN: ORNL, 2009.

Southworth, George, Max Greeley, Mark Peterson, Kenneth Lowe, and Richard Kettelle. Sources of Mercury to East Fork Poplar Creek Downstream from the Y-12 National Security Complex: Inventories and Export Rates. Oak Ridge: Oak Ridge National Laboratory, 2010.

TDEC, Tennessee Department of Environment and Conservation, Division of Water Pollution Control. "Proposed Total Maximum Daily Load (TMDL) for Mercury in East Fork Poplar Creek, Lower Clinch River Watershed, Preliminary Second Draft. Anderson and Roane Counties." Oak Ridge, TN, 2008.

Turner, R.R., and G.R. Southworth. "Mercury-Contaminated Industrial and Mining Sites in North America: an Overview with Selected Case Studies in Mercury Contaminated Sites," R. Ebinghaus, R. R. Turner, L. D. de Lacerda, O. Vasiliev, and W. Salomons (Eds.). Berlin: Springer-Verlag, 1999.

USEPA. "Appendix A Chemical Specific Data Delisting Technical Support Document." October 2008. http://www.epa.gov/reg5rcra/wptdiv/hazardous/delisting/appda1.pdf (accessed September 08, 2010).

USEPA. Development of Duration-Curve Based Methods for Quantifying Variability and Change in Watershed Hydrology and Water Quality. Cincinnati, Ohio: United States Environmental Protection Agency, 2008 b.

USEPA. "Guidance on the Development, Evaluation, and Application of Environmental Models." Council for Regulatory Environmental Modeling, U.S. Environmental Protection Agency, Washington, DC, 2009.

USEPA. "Mercury Study Report to Congress. Volume III. Fate and Transport of Mercury in the Environment." 1997.

USEPA. "Standard Operating Procedure for the Analysis of Residue, non-filterable (Suspended Solids), Water, Method 160.2 NS (Gravimetric, 103-105oC)." Region 5 Central Regional Laboratory, 1999.

USGS. "Contaminant Sorption by Soil and Bed Sediment." 2000.

Van Rijn, L. "Sediment Transport, Part I, Bed Load Transport." Journal of Hydraulic Engineering, 1984: 1431-1456.

Van Rijn, Leo. "Sediment Transport, Part II: Suspended Load Transport." Journal of Hydraulic Engineering 110, no. 11 (November 1984b): 1613-1641. 
Vermont Agency of Natural Resources. "Vermont Stream Geomorphic Assessment, Appendix O." 2009. http://bit.ly/gY33oq (accessed November 11, 2010).

Wehr, John, and Robert Sheath. Fresh water algae of North America, Ecology and classification. San Diego, CA: Academic Press, 2003.

Yin, Yujun, Herbert Allen, and C.P. Huang. "Kinetics of Mercury (II) Adsorption and Desorption in Soil." Environmental Science and Technology 31, no. 2 (1997): 496-502.

Yin, Yujun, Herbert Allen, and C.P. Huang. "Kinetics of Mercury (II) Adsorption and Desorption on soil." Environmental Science and Technology, 1997: 496-502. 


\section{APPENDICES}

Table 9 Wentworth grade scale for particle size to standardize sieve diameters (Garde and Tanga Raju. 1985)

\begin{tabular}{|c|c|}
\hline $\begin{array}{l}\text { Range in mm (Sieve } \\
\text { diameter) }\end{array}$ & Class Name \\
\hline$>256$ & Boulders \\
\hline 256-128 & Large Cobbles \\
\hline $128-64$ & Small Cobbles \\
\hline 64-32 & Very Coarse Gravel \\
\hline $32-16$ & Coarse Gravel \\
\hline $16-8$ & Medium Gravel \\
\hline $8-4$ & Fine Gravel \\
\hline 4-2 & Very Fine Gravel \\
\hline $2-1$ & Very, Coarse Sand \\
\hline $1-1.5$ & Coarse Sand \\
\hline $0.5-0.25$ & Medium Sand \\
\hline $0.25-0.125$ & Fine Sand \\
\hline $0.125-0.062$ & Very Fine Sand \\
\hline $0.062-0.031$ & Coarse Silt \\
\hline $0.031-0.016$ & Medium Silt \\
\hline $0.016-0.008$ & Fine Silt \\
\hline $0.008-0.004$ & Very Fine Silt \\
\hline $0.004-0.002$ & Coarse Clay \\
\hline $0.002-0.001$ & Medium Clay \\
\hline $0.0010-0.0005$ & Fine Clay \\
\hline $0.0005-0.00024$ & Very Fine Clay \\
\hline
\end{tabular}


Table 10 Suspended sediments characterization (DOE, Instream Contaminat Study Task 2, V2. Sediment Characterization. 1986)

\begin{tabular}{|c|c|c|c|c|c|c|c|c|}
\hline $\begin{array}{l}\mathrm{Km} \text { from } \\
\text { downstream }\end{array}$ & $\begin{array}{c}\text { Sieve } \\
\% \\
<0.0005 \\
\text { mm }\end{array}$ & $\begin{array}{c}\text { Sieve } \\
\% \\
<0.002 \\
\mathrm{~mm}\end{array}$ & $\begin{array}{c}\text { Sieve } \\
\% \\
<0.008 \\
\mathrm{~mm}\end{array}$ & $\begin{array}{c}\text { Sieve } \\
\% \\
<0.016 \\
\mathrm{~mm}\end{array}$ & $\begin{array}{c}\text { Sieve } \\
\% \\
<0.062 \\
\mathrm{~mm}\end{array}$ & $\begin{array}{c}\text { Sieve } \\
\% \\
<0.125 \\
\mathrm{~mm}\end{array}$ & $\begin{array}{c}\text { Sieve } \\
\% \\
<0.500 \\
\text { mm }\end{array}$ & $\begin{array}{c}\text { Sieve } \\
\% \\
<2.0 \\
\mathrm{~mm}\end{array}$ \\
\hline 2 & 7.7 & 26.7 & 41.9 & 49.3 & 64.0 & & & \\
\hline 4 & 7.0 & 14.5 & 24.2 & 29.9 & 44.0 & & & \\
\hline 4 & 8.3 & 17.0 & 28.7 & 35.5 & 48.6 & & & \\
\hline 4 & & & & & 29.2 & 35.5 & 71.3 & 98.9 \\
\hline 6 & 9.9 & 19.8 & 33.2 & 39.1 & 56.6 & 33.0 & 59.5 & 97.7 \\
\hline 6 & & & & & 26.6 & & & \\
\hline 7 & 13.9 & 27.0 & 44.2 & 51.6 & 81.9 & & & \\
\hline 9 & 11.6 & 21.3 & 36.8 & 48.4 & 64.6 & & & \\
\hline 9 & & & & & 31.1 & 40.2 & 63.4 & 90.3 \\
\hline 11 & 1.7 & 16.4 & 23.2 & 24.0 & 26.1 & 53.0 & 90.4 & 98.2 \\
\hline 11 & & & & & 44.2 & & & \\
\hline 13 & 10.7 & 17.2 & 26.2 & 32.4 & 41.0 & & & \\
\hline 13 & & & & & 18.1 & & 45.2 & 87.3 \\
\hline 13 & & & & & 31.9 & & 40.9 & 84.4 \\
\hline 13 & & & & & 33.7 & & 75.6 & 87.9 \\
\hline 15 & 8.9 & 16.1 & 26.0 & 30.6 & 40.3 & & & \\
\hline 16 & 9.3 & 16.9 & 27.6 & 33.1 & 42.2 & & & \\
\hline 18 & 9.1 & 15.8 & 25.3 & 28.8 & 41.5 & & & \\
\hline 20 & 13.2 & 22.3 & 32.3 & 42.1 & 53.0 & & & \\
\hline 21 & 5.1 & 11.2 & 18.0 & 21.7 & 31.9 & & & \\
\hline 22 & 4.8 & 7.5 & 12.2 & 14.9 & 24.1 & 36.6 & 60.3 & 86.4 \\
\hline 22 & 6.1 & 9.2 & 12.9 & 16.0 & 23.5 & 36.4 & 66.2 & 93.8 \\
\hline 22 & 3.6 & 8.6 & 15.5 & 18.6 & 35.7 & & & \\
\hline 22 & 4.6 & 11.7 & 19.4 & 23.9 & 28.5 & 47.9 & 69.2 & 94.7 \\
\hline 23 & 2.8 & 8.1 & 20.2 & 32.5 & 47.5 & 59.3 & 85.2 & 97.4 \\
\hline 23 & 10.0 & 16.2 & 24.6 & 29.7 & 44.4 & 55.0 & 83.8 & 96.3 \\
\hline
\end{tabular}


Table 11 Data Collected for the bed sediment characterization (Moran 1996)

\begin{tabular}{|c|c|c|c|c|c|}
\hline Station & $\begin{array}{l}\text { Grain } \\
\text { size, } \mathrm{mm}\end{array}$ & $\begin{array}{l}\% \\
\text { Passing }\end{array}$ & Station & $\begin{array}{l}\text { Grain } \\
\text { size, } m m\end{array}$ & $\begin{array}{l}\% \\
\text { Passing }\end{array}$ \\
\hline 64 & 38.1 & 100 & 48 & 38.1 & 97.533 \\
\hline 64 & 25.4 & 94.5323 & 48 & 25.4 & 89.602 \\
\hline 64 & 19.1 & 86.144 & 48 & 19.1 & 81.428 \\
\hline 64 & 12.7 & 69.115 & 48 & 12.7 & 68.416 \\
\hline 64 & 9.5 & 58.787 & 48 & 9.5 & 58.617 \\
\hline 64 & 4.76 & 41.061 & 48 & 4.76 & 39.748 \\
\hline 64 & 2 & 21.816 & 48 & 2 & 23.329 \\
\hline 64 & 1 & 11.584 & 48 & 1 & 11.707 \\
\hline 64 & 0.5 & 5.758 & 48 & 0.5 & 4.384 \\
\hline 64 & 0.243 & 3.558 & 48 & 0.243 & 3.091 \\
\hline 64 & 0.118 & 2.956 & 48 & 0.118 & 2.468 \\
\hline 64 & 0.063 & 2.488 & 48 & 0.063 & 2.034 \\
\hline 64 & 0.035 & 2.104 & 48 & 0.035 & 1.8 \\
\hline 64 & 0.02 & 1.658 & 48 & 0.02 & 1.496 \\
\hline 64 & 0.005 & 0.639 & 48 & 0.005 & 0.913 \\
\hline 64 & 0.00043 & 0 & 48 & 0.00043 & 0 \\
\hline 56 & 38.1 & 100 & 40 & 38.1 & 96.058 \\
\hline 56 & 25.4 & 97.537 & 40 & 25.4 & 94.594 \\
\hline 56 & 19.1 & 89.634 & 40 & 19.1 & 88.16 \\
\hline 56 & 12.7 & 74.622 & 40 & 12.7 & 73.882 \\
\hline 56 & 9.5 & 61.911 & 40 & 9.5 & 62.434 \\
\hline 56 & 4.76 & 40.393 & 40 & 4.76 & 43.326 \\
\hline 56 & 2 & 24.015 & 40 & 2 & 28.355 \\
\hline 56 & 1 & 13.354 & 40 & 1 & 16.03 \\
\hline 56 & 0.5 & 6.681 & 40 & 0.5 & 6.294 \\
\hline 56 & 0.243 & 5.608 & 40 & 0.243 & 3.116 \\
\hline 56 & 0.118 & 4.944 & 40 & 0.118 & 2.412 \\
\hline 56 & 0.063 & 4.308 & 40 & 0.063 & 1.953 \\
\hline 56 & 0.035 & 3.994 & 40 & 0.035 & 1.63 \\
\hline 56 & 0.02 & 3.548 & 40 & 0.02 & 1.3 \\
\hline 56 & 0.005 & 2.25 & 40 & 0.005 & 0.585 \\
\hline 56 & 0.00043 & 0 & 40 & 0.00043 & 0.011 \\
\hline
\end{tabular}


Continuation Table 11

\begin{tabular}{|c|c|c|c|c|c|}
\hline Station & $\begin{array}{c}\text { Grain } \\
\text { size, } m m\end{array}$ & $\begin{array}{c}\% \\
\text { Passing }\end{array}$ & Station & $\begin{array}{c}\text { Grain } \\
\text { size, } \mathbf{m m}\end{array}$ & $\begin{array}{c}\% \\
\text { Passing }\end{array}$ \\
\hline 32 & 38.1 & 96.058 & 6 & 38.1 & 100 \\
\hline 32 & 25.4 & 94.594 & 6 & 25.4 & 100 \\
\hline 32 & 19.1 & 88.16 & 6 & 19.1 & 92.575 \\
\hline 32 & 12.7 & 73.882 & 6 & 12.7 & 79.817 \\
\hline 32 & 9.5 & 62.434 & 6 & 9.5 & 71.089 \\
\hline 32 & 4.76 & 43.326 & 6 & 4.76 & 53.623 \\
\hline 32 & 2 & 28.355 & 6 & 2 & 33.278 \\
\hline 32 & 1 & 16.03 & 6 & 1 & 19.813 \\
\hline 32 & 0.5 & 6.294 & 6 & 0.5 & 9.244 \\
\hline 32 & 0.243 & 3.116 & 6 & 0.243 & 3.297 \\
\hline 32 & 0.118 & 2.412 & 6 & 0.118 & 2.258 \\
\hline 32 & 0.063 & 1.953 & 6 & 0.063 & 1.613 \\
\hline 32 & 0.035 & 1.63 & 6 & 0.035 & 1.317 \\
\hline 32 & 0.02 & 1.3 & 6 & 0.02 & 1.08 \\
\hline 32 & 0.005 & 0.585 & 6 & 0.005 & 0.002 \\
\hline 32 & 0.00043 & 0.011 & 6 & 0.00043 & 0 \\
\hline 24 & 38.1 & 97.499 & 2 & 38.1 & 100 \\
\hline 24 & 25.4 & 90.22 & 2 & 25.4 & 100 \\
\hline 24 & 19.1 & 79.006 & 2 & 19.1 & 100 \\
\hline 24 & 12.7 & 67.361 & 2 & 12.7 & 90.088 \\
\hline 24 & 9.5 & 58.232 & 2 & 9.5 & 81.112 \\
\hline 24 & 4.76 & 41.957 & 2 & 4.76 & 58.447 \\
\hline 24 & 2 & 27.399 & 2 & 2 & 30.214 \\
\hline 24 & 1 & 15.314 & 2 & 1 & 16.724 \\
\hline 24 & 0.5 & 6.803 & 2 & 0.5 & 5.419 \\
\hline 24 & 0.243 & 2.96 & 2 & 0.243 & 2.185 \\
\hline 24 & 0.118 & 2.158 & 2 & 0.118 & 1.529 \\
\hline 24 & 0.063 & 1.758 & 2 & 0.063 & 1.189 \\
\hline 24 & 0.035 & 1.473 & 2 & 0.035 & 0.76 \\
\hline 24 & 0.02 & 1.166 & 2 & 0.02 & 0.643 \\
\hline 24 & 0.005 & 0.528 & 2 & 0.005 & 0 \\
\hline 24 & 0.00043 & 0 & 2 & 0.00043 & 0 \\
\hline
\end{tabular}




\begin{tabular}{|l|r|r|}
\hline Station & \multicolumn{1}{c}{ Grain } \\
size, mm & \multicolumn{1}{c|}{ Passing } \\
\hline Lake reality & 38.1 & 100 \\
\hline Lake reality & 25.4 & 98.08 \\
\hline Lake reality & 19.1 & 97.813 \\
\hline Lake reality & 12.7 & 95.256 \\
\hline Lake reality & 9.5 & 92.613 \\
\hline Lake reality & 4.76 & 82.299 \\
\hline Lake reality & 2 & 68.108 \\
\hline Lake reality & 1 & 52.978 \\
\hline Lake reality & 0.5 & 39.235 \\
\hline Lake reality & 0.243 & 28.447 \\
\hline Lake reality & 0.118 & 14.921 \\
\hline Lake reality & 0.063 & 9.139 \\
\hline Lake reality & 0.035 & 6.778 \\
\hline Lake reality & 0.02 & 5.752 \\
\hline Lake reality & 0.005 & 3.677 \\
\hline Lake reality & 0.00043 & 0 \\
\hline USGS station 17 & 38.1 & 100 \\
\hline USGS station 17 & 25.4 & 95.329 \\
\hline USGS station 17 & 19.1 & 86.842 \\
\hline USGS station 17 & 12.7 & 73.016 \\
\hline USGS station 17 & 9.5 & 60.515 \\
\hline USGS station 17 & 4.76 & 39.703 \\
\hline USGS station 17 & 2 & 23.446 \\
\hline USGS station 17 & 1 & 13.696 \\
\hline USGS station 17 & 0.5 & 6.895 \\
\hline USGS station 17 & 0.243 & 4.55 \\
\hline USGS station 17 & 0.118 & 3.484 \\
\hline USGS station 17 & 0.063 & 2.83 \\
\hline USGS station 17 & 0.035 & 2.459 \\
\hline USGS station 17 & 0.02 & 2.055 \\
\hline USGS station 17 & 0.005 & 1.195 \\
\hline USGS station 17 & 0.00043 & 0 \\
\hline
\end{tabular}


Table 12 Boundary conditions for East Fork Poplar Creek

\begin{tabular}{|c|c|c|}
\hline Boundary Description & $\begin{array}{c}\text { Boundary } \\
\text { Type }\end{array}$ & Chainage \\
\hline Open & Q-h & 2663.78 \\
\hline Open & Inflow & 0.00 \\
\hline Point Source (outfalls) & Inflow & 7.70 \\
\hline Point Source (outfalls) & Inflow & 15.18 \\
\hline Point Source (outfalls) & Inflow & 28.53 \\
\hline Point Source (outfalls) & Inflow & 93.20 \\
\hline Point Source (outfalls) & Inflow & 99.91 \\
\hline Point Source (outfalls) & Inflow & 144.27 \\
\hline Point Source (outfalls) & Inflow & 253.30 \\
\hline Point Source (outfalls) & Inflow & 318.68 \\
\hline Point Source (outfalls) & Inflow & 364.90 \\
\hline Point Source (outfalls) & Inflow & 370.04 \\
\hline Point Source (outfalls) & Inflow & 390.36 \\
\hline Point Source (outfalls) & Inflow & 459.80 \\
\hline Point Source (outfalls) & Inflow & 459.80 \\
\hline Point Source (outfalls) & Inflow & 484.09 \\
\hline Point Source (outfalls) & Inflow & 487.20 \\
\hline Point Source (outfalls) & Inflow & 551.87 \\
\hline Point Source (outfalls) & Inflow & 582.15 \\
\hline Point Source (outfalls) & Inflow & 622.59 \\
\hline Point Source (outfalls) & Inflow & 628.42 \\
\hline Point Source (outfalls) & Inflow & 632.57 \\
\hline Point Source (outfalls) & Inflow & 697.07 \\
\hline Point Source (outfalls) & Inflow & 701.91 \\
\hline Point Source (outfalls) & Inflow & 716.78 \\
\hline Point Source (outfalls) & Inflow & 741.48 \\
\hline Point Source (outfalls) & Inflow & 764.02 \\
\hline Point Source (outfalls) & Inflow & 785.40 \\
\hline Point Source (outfalls) & Inflow & 787.82 \\
\hline Point Source (outfalls) & Inflow & 804.50 \\
\hline Point Source (outfalls) & Inflow & 820.95 \\
\hline
\end{tabular}




\begin{tabular}{|c|c|c|}
\hline Boundary Description & $\begin{array}{c}\text { Boundary } \\
\text { Type }\end{array}$ & Chainage \\
\hline Point Source (outfalls) & Inflow & 845.45 \\
\hline Point Source (outfalls) & Inflow & 883.15 \\
\hline Point Source (outfalls) & Inflow & 933.00 \\
\hline Point Source (outfalls) & Inflow & 943.00 \\
\hline Point Source (outfalls) & Inflow & 1020.79 \\
\hline Point Source (outfalls) & Inflow & 1059.24 \\
\hline Point Source (outfalls) & Inflow & 1177.78 \\
\hline Point Source (outfalls) & Inflow & 1347.74 \\
\hline Point Source (outfalls) & Inflow & 1399.70 \\
\hline Point Source (outfalls) & Inflow & 1946.27 \\
\hline Point Source (outfalls) & Inflow & 2050.33 \\
\hline Point Source (outfalls) & Inflow & 2398.77 \\
\hline Point Source (outfalls) & Inflow & 2456.77 \\
\hline Open & Q-h & 2663.78 \\
\hline Closed & & 0.00 \\
\hline
\end{tabular}


Table 13 UEFPC cross-sections description for chainages $0 \mathrm{~m}$ and $2663 \mathrm{~m}$

\begin{tabular}{|c|c|c|c|c|c|}
\hline Chainage & Level & Cross sec. & Hydraulic & Width & Resist. \\
\hline (m) & (m) & area $(\mathrm{m} 2)$ & radius $\mathrm{m}$ ) & (m) & factor \\
\hline \multirow[t]{20}{*}{0} & 281.575 & 0 & 0 & 0 & 30 \\
\hline & 281.775 & 0.648 & 0.161 & 4.645 & 30 \\
\hline & 281.976 & 1.677 & 0.333 & 5.573 & 30 \\
\hline & 282.176 & 2.862 & 0.507 & 6.24 & 30 \\
\hline & 282.377 & 4.176 & 0.679 & 6.863 & 30 \\
\hline & 282.578 & 5.615 & 0.847 & 7.497 & 30 \\
\hline & 282.778 & 7.19 & 1.01 & 8.208 & 30 \\
\hline & 282.979 & 8.906 & 1.168 & 8.882 & 30 \\
\hline & 283.179 & 10.746 & 1.326 & 9.444 & 30 \\
\hline & 283.38 & 12.67 & 1.487 & 9.74 & 30 \\
\hline & 283.58 & 14.653 & 1.654 & 10.037 & 30 \\
\hline & 283.781 & 16.696 & 1.822 & 10.334 & 30 \\
\hline & 283.981 & 18.793 & 1.991 & 10.562 & 30 \\
\hline & 284.182 & 20.932 & 2.163 & 10.766 & 30 \\
\hline & 284.383 & 23.112 & 2.336 & 10.971 & 30 \\
\hline & 284.583 & 25.332 & 2.509 & 11.175 & 30 \\
\hline & 284.784 & 27.594 & 2.683 & 11.38 & 30 \\
\hline & 284.984 & 29.897 & 2.857 & 11.584 & 30 \\
\hline & 285.185 & 32.24 & 3.03 & 11.757 & 30 \\
\hline & 285.385 & 34.608 & 3.205 & 11.864 & 30 \\
\hline \multirow[t]{20}{*}{2663.775} & 266.37 & 0 & 0 & 0 & 1 \\
\hline & 266.706 & 1.31 & 0.327 & 4.164 & 1 \\
\hline & 267.042 & 2.798 & 0.638 & 4.69 & 1 \\
\hline & 267.378 & 4.462 & 0.937 & 5.217 & 1 \\
\hline & 267.714 & 6.303 & 1.226 & 5.744 & 1 \\
\hline & 268.05 & 8.322 & 1.506 & 6.27 & 1 \\
\hline & 268.386 & 10.516 & 1.779 & 6.784 & 1 \\
\hline & 268.722 & 12.879 & 2.048 & 7.279 & 1 \\
\hline & 269.058 & 15.408 & 2.313 & 7.764 & 1 \\
\hline & 269.394 & 18.086 & 2.577 & 8.175 & 1 \\
\hline & 269.73 & 20.902 & 2.841 & 8.586 & 1 \\
\hline & 270.066 & 23.856 & 3.104 & 8.997 & 1 \\
\hline & 270.402 & 26.948 & 3.365 & 9.401 & 1 \\
\hline & 270.738 & 30.146 & 3.63 & 9.631 & 1 \\
\hline & 271.074 & 33.42 & 3.9 & 9.86 & 1 \\
\hline & 271.41 & 36.772 & 4.174 & 10.089 & 1 \\
\hline & 271.746 & 40.2 & 4.45 & 10.318 & 1 \\
\hline & 272.082 & 43.706 & 4.726 & 10.547 & 1 \\
\hline & 272.418 & 47.288 & 5.002 & 10.828 & 1 \\
\hline & 272.754 & 51.346 & 5.214 & 13.071 & 1 \\
\hline
\end{tabular}


Table 14 Dissolved and particulate mercury in the water column, observed data from UEFPC-Station 17 (Bechtel Jacobs 1999)

\begin{tabular}{|c|c|c|c|c|c|c|}
\hline Date & $\begin{array}{c}\text { TSS } \\
\mathrm{mg} / \mathrm{L}\end{array}$ & $\begin{array}{c}\text { Diss. Hg } \\
\text { ug/L }\end{array}$ & $\begin{array}{c}\text { Part. Hg } \\
\text { ug/L }\end{array}$ & $\begin{array}{c}\text { Total Hg } \\
\text { ug/L }\end{array}$ & $\begin{array}{c}\text { Part.Hg } \\
\%\end{array}$ & $\begin{array}{c}\text { Diss. Hg } \\
\%\end{array}$ \\
\hline $02 / 19 / 97$ & 2.20 & 0.114 & 0.506 & 0.620 & $82 \%$ & $18 \%$ \\
\hline $06 / 20 / 97$ & 2.90 & 0.089 & 0.409 & 0.498 & $82 \%$ & $18 \%$ \\
\hline $11 / 20 / 97$ & 2.79 & 0.075 & 0.441 & 0.516 & $85 \%$ & $15 \%$ \\
\hline $08 / 11 / 98$ & 11.07 & 0.070 & 0.922 & 0.992 & $93 \%$ & $7 \%$ \\
\hline $12 / 17 / 98$ & 7.01 & 0.100 & 0.426 & 0.526 & $81 \%$ & $19 \%$ \\
\hline Average & 5.19 & 0.090 & 0.541 & 0.630 & $85 \%$ & $15 \%$ \\
\hline
\end{tabular}


Table 15 Observed dissolved mercury in pore water, UEFPC (Source: OREIS database)

\begin{tabular}{|c|c|c|}
\hline Station & Date & $\begin{array}{c}\text { Concentration } \\
\text { mg/L }\end{array}$ \\
\hline UEFPC-3 & $12 / 11 / 1996$ & $4.00 \mathrm{E}-08$ \\
\hline UEFPC-2 & $12 / 11 / 1996$ & $4.00 \mathrm{E}-08$ \\
\hline UEFPC-1 & $12 / 11 / 1996$ & $4.00 \mathrm{E}-08$ \\
\hline UEFPC-4 & $12 / 12 / 1996$ & $1.20 \mathrm{E}-07$ \\
\hline UEFPC-1 & $12 / 11 / 1996$ & $1.70 \mathrm{E}-07$ \\
\hline UEFPC-5 & $12 / 12 / 1996$ & $6.90 \mathrm{E}-07$ \\
\hline UEFPC-1 & $12 / 11 / 1996$ & $7.29 \mathrm{E}-06$ \\
\hline UEFPC-1 & $12 / 11 / 1996$ & $7.29 \mathrm{E}-06$ \\
\hline UEFPC-3 & $12 / 11 / 1996$ & $2.33 \mathrm{E}-05$ \\
\hline UEFPC-4 & $12 / 12 / 1996$ & $3.67 \mathrm{E}-05$ \\
\hline UEFPC-5 & $12 / 12 / 1996$ & $5.00 \mathrm{E}-05$ \\
\hline UEFPC-2 & $12 / 11 / 1996$ & $7.63 \mathrm{E}-05$ \\
\hline UEFPC-5 & $12 / 12 / 1996$ & $2.00 \mathrm{E}-03$ \\
\hline UEFPC-4 & $12 / 12 / 1996$ & $2.00 \mathrm{E}-03$ \\
\hline UEFPC-3 & $12 / 11 / 1996$ & $2.00 \mathrm{E}-03$ \\
\hline UEFPC-2 & $12 / 11 / 1996$ & $2.00 \mathrm{E}-03$ \\
\hline UEFPC-1 & $12 / 11 / 1996$ & $2.00 \mathrm{E}-03$ \\
\hline UEFPC-1 & $12 / 11 / 1996$ & $2.00 \mathrm{E}-03$ \\
\hline Average & & $6.78 \mathrm{E}-04$ \\
\hline St. Dev. & & $9.62 \mathrm{E}-04$ \\
\hline & &
\end{tabular}


Table 16 Observed adsorbed mercury in sediment, UEFPC (OREIS database)

\begin{tabular}{|c|c|c|}
\hline Station & Date & $\begin{array}{c}\text { Concentration } \\
\mathrm{mg} / \mathrm{kg}\end{array}$ \\
\hline UEFPC-2 & $12 / 11 / 1996$ & 5.26 \\
\hline UEFPC-1 & $12 / 11 / 1996$ & 5.95 \\
\hline UEFPC-1 & $12 / 11 / 1996$ & 6.37 \\
\hline UEFPC-1 & $12 / 11 / 1996$ & 7.22 \\
\hline UEFPC-1 & $12 / 11 / 1996$ & 7.48 \\
\hline UEFPC-1 & $12 / 11 / 1996$ & 12.70 \\
\hline UEFPC-1 & $12 / 11 / 1996$ & 14.08 \\
\hline UEFPC-5 & $12 / 12 / 1996$ & 26.60 \\
\hline UEFPC-5 & $12 / 12 / 1996$ & 28.53 \\
\hline UEFPC-4 & $12 / 12 / 1996$ & 29.73 \\
\hline UEFPC-3 & $12 / 11 / 1996$ & 30.08 \\
\hline UEFPC-4 & $12 / 12 / 1996$ & 35.40 \\
\hline UEFPC-3 & $12 / 11 / 1996$ & 38.65 \\
\hline UEFPC-5 & $12 / 12 / 1996$ & 38.68 \\
\hline UEFPC-3 & $12 / 11 / 1996$ & 46.60 \\
\hline UEFPC-4 & $12 / 12 / 1996$ & 50.99 \\
\hline UEFPC-2 & $12 / 11 / 1996$ & 100.50 \\
\hline UEFPC-2 & $12 / 11 / 1996$ & 125.31 \\
\hline Average & & 33.90 \\
\hline St. Dev. & & 32.56 \\
\hline
\end{tabular}

